\title{
Molecular genetics of prostate cancer: new prospects for old challenges
}

\author{
Michael M. Shen ${ }^{1,2,3,6}$ and Cory Abate-Shen ${ }^{3,4,5,7}$ \\ ${ }^{1}$ Department of Medicine, Columbia University Medical Center, New York, New York 10032, USA; ${ }^{2}$ Department of Genetics \\ and Development, Columbia University Medical Center, New York, New York 10032, USA; ${ }^{3}$ Herbert Irving Comprehensive \\ Cancer Center, Columbia University Medical Center, New York, New York 10032, USA; ${ }^{4}$ Department of Urology, Columbia \\ University Medical Center, New York, New York 10032, USA; ${ }^{5}$ Department of Pathology and Cell Biology, Columbia University \\ Medical Center, New York, New York 10032, USA
}

\begin{abstract}
Despite much recent progress, prostate cancer continues to represent a major cause of cancer-related mortality and morbidity in men. Since early studies on the role of the androgen receptor that led to the advent of androgen deprivation therapy in the 1940s, there has long been intensive interest in the basic mechanisms underlying prostate cancer initiation and progression, as well as the potential to target these processes for therapeutic intervention. Here, we present an overview of major themes in prostate cancer research, focusing on current knowledge of principal events in cancer initiation and progression. We discuss recent advances, including new insights into the mechanisms of castration resistance, identification of stem cells and tumor-initiating cells, and development of mouse models for preclinical evaluation of novel therapuetics. Overall, we highlight the tremendous research progress made in recent years, and underscore the challenges that lie ahead.
\end{abstract}

In 2009 , there were $\sim 192,280$ new cases of prostate cancer reported and 27,360 related deaths in the United States (American Cancer Society 2009). Although the age-adjusted rate of cancer deaths has decreased steadily in the past 10 years, prostate cancer remains the second leading cause of cancer death in men. Since we last reviewed this topic 10 years ago (Abate-Shen and Shen 2000), there have been numerous advances in basic research on prostate cancer initiation and progression, as well as new clinical advances that have improved patient outcome. Below, we review the principal features of prostate cancer, highlighting key molecular events of initiation and progression and major targets for clinical intervention. When feasible, we

[Keywords: Androgen receptor; castration resistance; mouse models; prostate cancer; stem cells]

Correspondence.

${ }^{6}$ E-MAIL mshen@columbia.edu; FAX (212) 851-4572.

${ }^{7}$ E-MAIL cabateshen@columbia.edu; FAX (212) 851-4572.

Article is online at http://www.genesdev.org/cgi/doi/10.1101/gad.1965810. cited primary references for the key findings discussed, particularly those published within the past 10 years.

\section{Major clinical challenges in prostate cancer}

Prostate cancer has been recognized as a clinical entity since antiquity, when it was first described by the ancient Egyptians, while surgical procedures to remove the prostate were developed >100 years ago (Capasso 2005). However, the availability of a highly accessible blood test for prostate-specific antigen (PSA) has revolutionized the diagnosis of prostate cancer over the past three decades. PSA is a kallikrein-related serine protease that is produced in normal prostate secretions, but is released into the blood as a consequence of disruption of normal prostate architecture (Lilja et al. 2008).

Men that have elevated PSA levels typically undergo biopsy to assess the potential presence of prostate cancer. Following biopsy, histopathological grading of prostate tissue is performed by Gleason scoring, which classifies tumors from 1 to 5 (most to least differentiated) based on their most prevalent architecture, and assigns a combined score that is the sum of the two most common patterns (Mellinger et al. 1967; Epstein 2010). Patients are also diagnosed by the status of their primary tumors, from organ-confined to fully invasive (T1-4), with or without lymph node involvement ( $\mathrm{N} 0$ or 1 ), and the presence and degree of distant metastases (M0 and 1a-c) (Ohori et al. 1994). If prostate cancer is diagnosed, conventional treatment regimens include surgical excision of the prostate (radical prostatectomy), or irradiation through external beam therapy or implantation of radioactive "seeds" (brachytherapy). In the case of advanced cancer, these regimens are usually followed or substituted with androgen deprivation therapy, which initially will reduce tumor burden and/or circulating PSA to low or undetectable levels, but ultimately the disease will recur in most cases.

At present, there are several major clinical challenges associated with this conventional paradigm for prostate cancer diagnosis and treatment. Each of these significantly impacts the effective management of prostate cancer, and is the subject of investigations in basic research on prostate tumor biology. 


\section{Distinguishing indolent vs. aggressive disease}

Recent changes in recommendations that now suggest later and less frequent PSA screenings highlight a major clinical challenge for prostate cancer diagnosis and treatment (Wolf et al. 2010). These new recommendations were proposed because the widespread use of PSA testing has led to a vast increase in the diagnosis of patients with clinically localized low Gleason grade carcinomas that may not require treatment, since their tumors are relatively indolent. In particular, patients with a Gleason pattern of 3 or less almost never relapse after local therapy, and very likely can be managed conservatively with "watchful waiting"; nonetheless, a small fraction of these tumors will progress rapidly and require immediate treatment (Albertsen et al. 2005; Eggener et al. 2007; Lu-Yao et al. 2009).

Consequently, a major clinical challenge is posed by the current inability to readily distinguish indolent from aggressive tumors in prostate cancer patients who present with low Gleason grade tumors upon biopsy (Sartor et al. 2008). The absence of this prognostic information has led to a significant "overtreatment" of patients who would otherwise require only conservative management. Thus, the impact of treatment on prostate cancer survival is small, most likely because overdiagnosis and overtreatment dilutes the benefits of therapy for those who require intervention. This prognostic challenge could be addressed by better understanding of the molecular basis of cancer initiation, which should ultimately lead to the identification of biomarkers that distinguish between indolent and aggressive forms of prostate cancer. At present, however, available panels of molecular biomarkers do not provide greater prognostic significance than Gleason grade determination (True et al. 2006).

\section{Castration-resistant prostate cancer}

Circulating androgens are essential for normal prostate development as well as the onset of prostate cancer through their interactions with the androgen receptor (AR). As shown by Huggins and colleagues in the 1940s (Huggins and Hodges 1941), removal of testicular androgens by surgical or chemical castration will lead to regression of prostate tumors. However, androgen depletion is usually associated with the recurrence of prostate cancer, as monitored by rising PSA levels, and this recurrent disease is termed "castration resistant." (The term "castration resistance" has generally replaced "androgen independence" in usage, as it has become apparent that advanced prostate cancer remains dependent on AR function, as discussed below.) Unfortunately, castration-resistant prostate cancer has been essentially untreatable, with the most effective standard chemotherapeutic regimens resulting in a mean increase in survival time of 2 mo (Petrylak et al. 2004; Tannock et al. 2004). Therefore, a second major clinical challenge that could be significantly impacted by basic research in prostate cancer biology is the elucidation of pathways of castration resistance, which could lead to the identification of new therapeutic approaches.

\section{Bone tropism of prostate cancer metastasis}

A third major clinical challenge corresponds to the propensity for advanced prostate cancer to metastasize to bone, which is primarily responsible for its effect on patient morbidity as well as mortality. Thus, unlike other epithelial tumors that occasionally metastasize to bone, metastatic prostate cancer almost invariably metastasizes to bone, and furthermore displays characteristic osteoblastic rather than osteolytic lesions (Logothetis and Lin 2005). Despite the clinical relevance of bone metastasis, the molecular mechanisms that underlie the bone tropism of prostate cancer are not well understood. This gap in knowledge is due in part to difficulties in obtaining metastatic tissue from patients, as well as to difficulties in generating mouse models that display bone metastasis.

At present, relatively little is known about the molecular mechanisms underlying the bone tropism of prostate cancer metastasis. Experimental models for investigation of bone metastases are limited to a small range of xenograft models that typically rely on intracardiac or intratibial injection of highly transformed tumor cells to induce metastases (Corey et al. 2002; Singh and Figg 2005). To date, despite the availability of genetically engineered mouse models that display secondary metastases, there is no autochthonous model that reliably generates bone metastases at an appreciable frequency.

\section{Development of the prostate gland}

\section{Anatomy and histology}

In men, the prostate gland is a walnut-sized tissue surrounding the urethra at the base of the bladder, and produces important components of the seminal fluid. Although the adult prostate lacks discernible lobular structure, the classic work of McNeal (1969, 1981, 1988) defined the human prostate as having a zonal architecture, corresponding to central, periurethral transition, and peripheral zones, together with an anterior fibromuscular stroma (Timms 2008). Importantly, the outermost peripheral zone occupies the most volume, and harbors the majority of prostate carcinomas. In contrast, benign prostatic hyperplasia (BPH), a common nonmalignant condition found in older men, arises from the transition zone.

Unlike the human prostate, the mouse prostate consists of multiple lobes that have distinct patterns of ductal branching, histological appearance, gene expression, and secretory protein expression (Cunha et al. 1987). These correspond to the ventral, lateral, dorsal, and anterior lobes, with the dorsal and lateral lobes often combined as the dorsolateral lobe for analysis. Although it is sometimes asserted that the mouse dorsolateral lobe is most analogous to the human peripheral zone, particularly with respect to prostate cancer, there is no consensus agreement among pathologists to support this conclusion (Shappell et al. 2004). However, analyses of gene expression profiling data support the idea that the dorsolateral lobe is most similar to the peripheral zone of the human prostate (Berquin et al. 2005). 
At the histological level, both the mouse and human prostate contain a pseudostratified epithelium with three differentiated epithelial cell types: luminal, basal, and neuroendocrine (CS Foster et al. 2002; van Leenders and Schalken 2003; Hudson 2004; Shappell et al. 2004; Peehl 2005). The luminal epithelial cells form a continuous layer of polarized columnar cells that produce protein secretions and express characteristic markers such as cytokeratins 8 and 18, as well as high levels of AR. Basal cells are located beneath the luminal epithelium, and express p63 and the high-molecular-weight cytokeratins 5 and 14, but express AR at low or undetectable levels. Finally, neuroendocrine cells are rare cells of unknown function that express endocrine markers such as chromogranin A and synaptophysin, but are AR-negative.

\section{Epithelial-mesenchymal interactions}

The prostate is an endodermal tissue that arises during late embryogenesis through ductal budding from the anterior urogenital sinus epithelium. Formation of the prostate is an inductive event that requires reciprocal interactions between the urogenital sinus mesenchyme and epithelium, and is dependent on testicular androgen synthesis. The fundamental parameters of these epithelial-mesenchymal interactions were defined in classical tissue recombination studies by Cunha and colleagues /Cunha et al. 1987; Cunha 2008). These studies demonstrated that an AR-dependent signal from the urogenital mesenchyme is required for prostate formation, while AR is not initially required in the urogenital epithelium for prostate organogenesis, but is subsequently necessary for epithelial differentiation and secretory protein expression. Thus, androgens act indirectly on the urogenital mesenchyme to mediate prostate induction. These findings have been subsequently confirmed by conditional gene targeting of AR in the prostate epithelium (Wu et al. 2007).

More recently, molecular analyses have implicated several developmental signaling pathways in mediating epithelial-mesenchymal interactions during prostate organogenesis, including the Wnt, fibroblast growth factor (FGF), and Hedgehog pathways (Marker et al. 2003; Prins and Putz 2008). For example, ligands and inhibitors for the canonical Wnt/ $\beta$-catenin as well as noncanonical pathways are expressed in both epithelial and mesenchymal compartments during early prostate organogenesis (Pritchard and Nelson 2008), and abrogation of noncanonical Wnt5a signaling leads to defects in ductal morphogenesis (Huang et al. 2009). In addition, the FGF pathway is clearly required for prostate formation, as null mutants for the mesenchymally expressed Fgf10 mostly lack prostate budding (Donjacour et al. 2003), while conditional deletion of Fgfr2, which encodes the receptor for FGF10, or the downstream signaling component Frs $2 \alpha$ in prostate epithelium results in defects in branching morphogenesis (Lin et al. 2007; Zhang et al. 2008). Finally, the Hedgehog signaling pathway is also involved in prostate formation, as the Shh ligand is expressed in urogenital epithelium; the downstream components Smo, Ptc1, and Gli1 are expressed in urogenital mesenchyme (Lamm et al. 2002; Freestone et al.
2003; Berman et al. 2004); and loss of Shh pathway activity results in loss of prostate formation and/or defective ductal branching (Podlasek et al. 1999; Freestone et al. 2003; Berman et al. 2004). However, it remains unclear whether these phenotypes are mediated directly through redundant ligands functioning through the Hedgehog pathway (Doles et al. 2006), or indirectly through a reduction in androgen signaling (Freestone et al. 2003; Berman et al. 2004).

\section{Natural history of prostate cancer}

\section{Latent and clinical cancer}

Prostate cancer is generally regarded as multifocal, since primary tumors often contain multiple independent histologic foci of cancer that are often genetically distinct (Aihara et al. 1994; Bostwick et al. 1998; Macintosh et al. 1998; Mehra et al. 2007a; Clark et al. 2008). In contrast, despite the phenotypic heterogeneity of metastatic prostate cancer (Shah et al. 2004), molecular and cytogenetic analyses show that multiple metastases in the same patient are clonally related, indicating that advanced prostate cancer is monoclonal (Mehra et al. 2008; Liu et al. 2009). These findings suggest that metastatic prostate cancer may arise from the selective advantage of individual clones during cancer progression; however, this process of clonal evolution may also represent the consequence of therapeutic interventions such as androgen deprivation, which may differentially target cells of varying malignant potential.

The heterogeneity of prostate cancer is potentially relevant for understanding the distinction between latent and clinical disease, and the strong correlation between prostate cancer progression and aging (Fig. 1). Although prostate cancer is a disease of older men, studies of prostate specimens from healthy men in their 20 s to 40 s show the frequent presence of histologic foci of prostate cancer (Yatani et al. 1989; Sakr et al. 1994; Shiraishi et al. 1994), suggesting that cancer initiation has already taken place at a relatively early age. Combined with the evidence that prostate cancer is multifocal, it appears that the prostate gland can be the site of multiple neoplastic transformation events, many of which give rise only to latent prostate cancer that does not progress to clinically detectable disease. It is conceivable that clinical prostate cancer initiates from a different pathogenic program than latent prostate cancer. Alternatively, most latent prostate cancer foci may not undergo critical activating events that lead to clinical disease, or may remain under active suppression sufficient to maintain these foci in a subclinical state. As discussed above, the advent of PSA screening has led to a vast increase in the diagnoses of prostate cancer, many of which presumably represent latent or indolent forms of the disease that at present are difficult to distinguish from cancers that will become more aggressive; this highlights the critical need for improved molecular markers and/or other approaches to augment the histological assessment of prostate cancer for more effective diagnosis and management. 


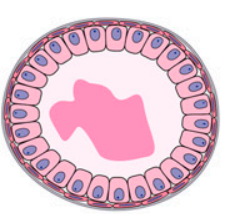

Normal epithelium

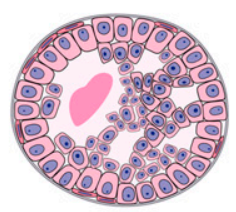

Prostatic intraepithelial neoplasia (PIN)

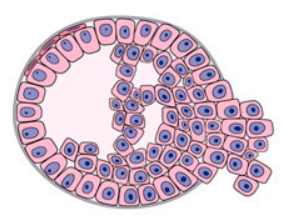

Adenocarcinoma (latent)

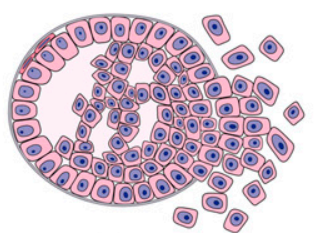

Adenocarcinoma (clinical)

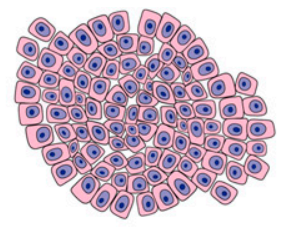

Metastasis \begin{tabular}{|ll}
\hline Initiation & Progression
\end{tabular}

Inflammation

Oxidative/DNA damage

Telomere shortening

Senescence

Re-activation of developmental signaling pathways

ERK/MAPK activation
Treatment

Castration-resistance

EMT

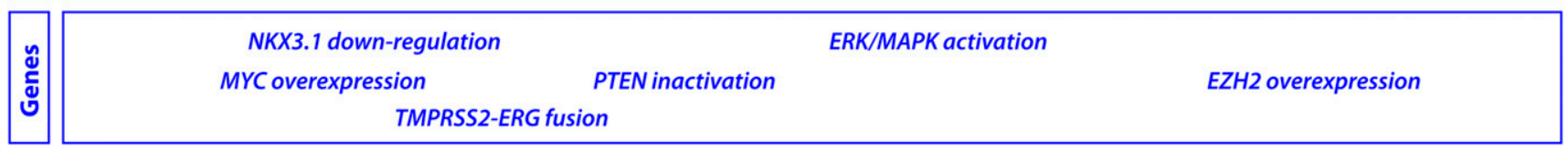

Figure 1. Progression pathway for human prostate cancer. Stages of progression are shown, together with molecular processes and genes/pathways that are likely to be significant at each stage. Adapted from Abate-Shen and Shen (2000).

Prostatic intraepithelial neoplasia (PIN) and prostate cancer

It is widely accepted that PIN represents a precursor for prostate cancer, although this relationship has not been demonstrated conclusively (Bostwick 1989; DeMarzo et al. 2003). PIN is generally characterized at the histological level by the appearance of luminal epithelial hyperplasia, reduction in basal cells, enlargement of nuclei and nucleoli, cytoplasmic hyperchromasia, and nuclear atypia; in addition, high-grade PIN lesions generally display marked elevation of cellular proliferation markers (Bostwick 1989; Shappell et al. 2004). In contrast with prostate cancer, however, basal cells are reduced in number in PIN, but are not absent.

Although human prostate cancer displays significant phenotypic heterogeneity, $>95 \%$ of prostate cancers are classified pathologically as adenocarcinoma, which has a strikingly luminal phenotype (Fig. 2). In biopsy specimens, prostate adenocarcinoma diagnosis can be confirmed by the absence of immunostaining using p 63 and cytokeratin 5/14 antibodies, both of which detect basal cells (Humphrey 2007; Grisanzio and Signoretti 2008). In addition, a diagnosis of prostate cancer is supported by elevated immunostaining for $\alpha$-methylacyl-CoA racemase (AMACR), a luminal marker that is overexpressed in carcinoma (Luo et al. 2002; Jiang et al. 2005; Humphrey 2007). Similarly, prostate cancer arising in many mouse models displays a relatively luminal phenotype (Kim et al. 2002d; X Ma et al. 2005). However, the overt histological appearance of prostate carcinoma in most genetically engineered mouse models often differs from that of typical human prostate cancer (Fig. 2).

\section{Subtypes of prostate cancer}

A notable difference between prostate cancer and other epithelial tumors, such as breast cancer, is the lack of distinguishable histopathological subtypes that differ in their prognosis or treatment response. The vast majority of prostate cancers correspond to acinar adenocarcinomas that express AR, while other categories of prostate cancer-such as ductal adenocarcinoma, mucinous carcinoma, and signet ring carcinoma-are extremely rare

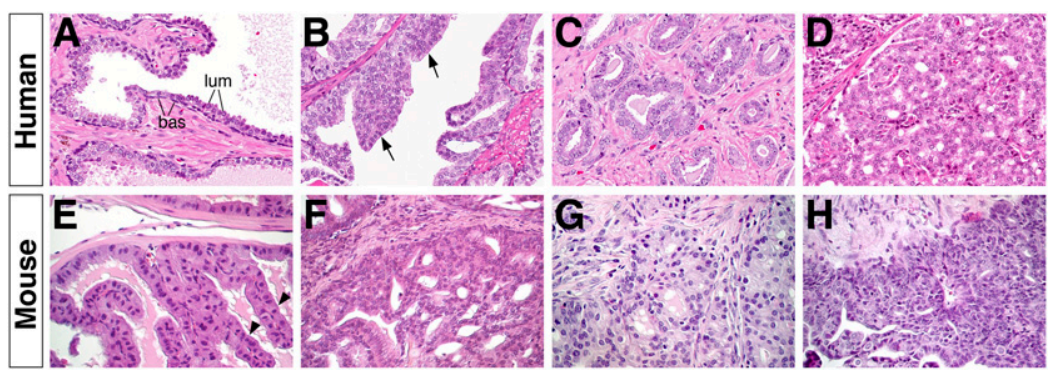

Figure 2. Histopathology of human and mouse prostate cancer. $(A-D)$ Hematoxylin-eosin-stained sections of human prostate. (A) Benign normal tissue, with representative basal (bas) and luminal (lum) cells indicated. (B) PIN; arrows indicate regions of hyperplastic epithelium. $(C)$ Well-differentiated adenocarcinoma. $(D)$ Poorly differentiated adenocarcinoma. $(E-H)$ Hematoxylin-eosinstained sections of anterior prostate from genetically engineered mouse models. (E) Normal tissue, with characteristic papillary tufting (arrowheads). (F) High-grade PIN. $(G)$ Prostate carcinoma. $(H)$ Prostate carcinoma with an invasive phenotype. We thank Dr. Robert Cardiff and Alexander Borowsky (School of Medicine, University of California at Davis) for providing images of human prostate specimens. 
(Grignon 2004). Perhaps the most significant histological variant is neuroendocrine prostate cancer, which is generally classified as either small cell carcinoma or a carcinoid tumor, and represents $<2 \%$ of prostate cancer cases (Grignon 2004). However, focal regions of neuroendocrine differentiation are more commonly observed in prostate adenocarcinoma, particularly following recurrence after prostatectomy and androgen deprivation therapy (Yuan et al. 2007; Komiya et al. 2009), and expression of the neuroendocrine marker chromogranin $\mathrm{A}$ is associated with the development of castration-resistant tumors and shortened time to disease recurrence (Kokubo et al. 2005; Berruti et al. 2007). This prevalence of neuroendocrine differentiation after recurrence may be due to the lack of AR expression by neuroendocrine cells, which are inherently castration-resistant.

While evidence of major subtypes of prostate cancer is lacking at the histopathological level, recent genomic analyses have provided increasing evidence for molecularly defined subtypes (Tomlins et al. 2008b; Palanisamy et al. 2010; Taylor et al. 2010). In particular, expression profiling analyses of prostate cancer specimens have not strictly defined molecular signatures associated with distinct cancer subtypes that specifically correlate with disease outcome (Singh et al. 2002; Lapointe et al. 2004; Tomlins et al. 2007b). However, oncogenomic pathway analyses that integrate analyses of gene expression, copy number alterations, and exon resequencing may provide a unified approach for distinguishing prostate cancer subtypes and stratifying patient outcome (Taylor et al. 2010). Furthermore, the existence of molecular subtypes has been supported by analyses of chromosomal rearrangements associated with prostate cancer; for example, prostate cancers containing the TMPRSS2-ERG translocation may be distinct from those that up-regulate SPINK1, which encodes a secreted trypsin inhibitor (Mehra et al. 2007a; Tomlins et al. 2008b). Ongoing studies will undoubtedly assess whether these subtypes correlate with disease outcome or treatment response.

\section{Metastasis}

As noted above, although common sites of secondary metastasis for prostate cancer are lung, liver, and pleura, if prostate cancer metastasizes, it invariably goes to bone, where it forms characteristic osteoblastic lesions (Bubendorf et al. 2000; Logothetis and Lin 2005). Given the clinical importance of metastasis for patient outcome, the ability of prostate tumor cells to disseminate into the bone marrow and peripheral blood has been investigated in detail. Notably, a recent study showed that bona fide circulating tumor cells could be detected in the bone marrow of a significant proportion of patients with localized disease, suggesting that disseminated tumor cells have not attained full metastatic capability (Holcomb et al. 2008). Consistent with this interpretation, circulating tumor cells from patients with metastatic disease show multiple chromosomal rearrangements typical of advanced prostate cancer, consistent with genomic instability acquired during cancer progres- sion (Holcomb et al. 2008; Attard et al. 2009c; Leversha et al. 2009). However, the relationship of disseminated tumor cells to the formation of metastases remains unresolved, and the molecular factors that promote metastases of prostate cancer to bone are poorly defined.

\section{Mouse models of prostate cancer}

\section{Xenograft models}

Traditionally, in vivo studies of prostate cancer have extensively used xenograft models of human prostate cancer, using cell lines or prostate tumors implanted into immunodeficient mice, either orthotopically into the prostate or transplanted onto the flank. For instance, xenografts derived from LNCaP cells have been used to generate genetically-related lines that vary in their androgen responsivity and metastatic potential (Thalmann et al. 2000). Similarly, several xenografts have been developed by transplantation of human prostate tumors, including the LuCaP and LAPC series, which display a spectrum of prostate cancer phenotypes (Ellis et al. 1996; Craft et al. 1999b). Several of these human tissue xenografts have also given rise to prostate cancer cell lines, such as the VCaP line, which was derived from a bone metastasis (Korenchuk et al. 2001).

Analyses of xenografts have yielded a vast amount of information about molecular mechanisms of prostate cancer, and have been useful for chemotherapeutic approaches. However, xenograft models are limited by a heterologous microenviroment (since human cells/tissues are grafted in mice), an inability to analyze stromal components (unless orthotopic grafting is employed), the lack of endogenous immune response (since the host mice are immunodeficient), and the lack of diversity of available established cell lines. In particular, the limited number of available prostate cancer cell lines is likely related to inherent difficulties in culturing luminal epithelial cells (Peehl 2005) (existing prostate cell lines have been reviewed in detail) (Sobel and Sadar 2005a,b). Of particular concern is that existing cell lines may have uncertain origins, as has been demonstrated for at least one "prostate" cell line that was actually derived from a bladder carcinoma line (van Bokhoven et al. 2001). Additionally, cell lines may have anomalous molecular properties (e.g., loss of AR expression and lack of TMPRSS2-ERG fusions) when compared with most human prostate tumors (Sobel and Sadar 2005a,b), which may limit their applicability. Nonetheless, xenograft systems remain popular for studies of chemotherapeutics, primarily due to their ease of use. Moreover, since they are of human origin, xenografts may be more likely to recapitulate molecular events involved in human prostate tumorigenesis than other experimental models.

\section{Tissue reconstitution models}

The tissue recombination and renal grafting methods originally developed to study epithelial-mesenchymal interactions during prostate organogenesis can be extended for investigation of prostate tumorigenesis in vivo. In particular, immortalized human and mouse prostate 
epithelial cell lines are available that can reconstitute benign prostate tissue with relatively normal histology following recombination with rodent embryonic urogenital mesenchyme and grafting into immunodeficient recipients (Hayward et al. 2001; Gao et al. 2004a; Jiang et al. 2010). Using such cell lines, gene expression can be directly manipulated in culture by overexpression or knockdown methods, followed by analysis of potential tumor phenotypes in vivo. Similarly, stromal components can also be investigated in tissue recombinants using immortalized urogenital mesenchyme cell lines to facilitate genetic manipulation (Shaw et al. 2006), or using carcinoma-associated fibroblasts (Olumi et al. 1999). Furthermore, this overall approach can been greatly extended by efficient lentiviral infection of dissociated prostate epithelial cells, followed by tissue recombination, allowing for overexpression and knockdown approaches for analysis of gene function (Xin et al. 2003, 2006; Zong et al. 2009). Finally, grafting methods can be used to evaluate the relative contribution of epithelial and stromal prostatic components for cancer progression (Kim et al. 2002a; Jeong et al. 2008), as well as to study cancer phenotypes in the prostate glands of mouse strains that display embryonic lethality, even prior to prostate formation (Wang et al. 2000). Thus, tissue reconstitution methods represent powerful approaches to studying cancer mechanisms in both mouse and human prostates.

\section{Genetically engineered models}

The use of genetically engineered transgenic and knockout mice to produce autochthonous models of prostate cancer has represented a major avenue for prostate cancer investigations (Table 1). Most first-generation prostate cancer models used transgenes that overexpress potent viral oncogenes, resulting in highly aggressive disease that can often lead to metastatic cancer (Winter et al. 2003; Kasper 2005). Among these models are the wellstudied TRAMP (transgenic adenocarcinoma of the prostate) mouse, which carries a minimal probasin promoter driving both SV40 large T and small $\mathrm{t}$ antigen (Greenberg et al. 1995), and the LADY models that use a larger probasin promoter and express large $\mathrm{T}$ antigen only (Masumori et al. 2001). However, transgenic mice that overexpress SV40 large T antigen typically have short latency, and develop cancer with features of neuroendocrine differentiation (Kaplan-Lefko et al. 2003; Shappell et al. 2004). Nonetheless, these first-generation models have provided numerous important insights into prostate cancer mechanisms.

A second generation of prostate cancer models has used loss-of-function mutations in candidate genes implicated in the genesis of human prostate cancer (Table 1). Several popular models have employed null mutations in genes of interest, including Nkx3.1 and Pten (phosphatase and tensin homolog deleted from chromosome 10) (discussed below); for example, Nkx3.1; Pten double mutants show accelerated formation of high-grade PIN and invasive cancer (Kim et al. 2002d; Abate-Shen et al. 2003). Other commonly used models have employed conditional de- letion mediated by the $\mathrm{Pb}$-Cre4 transgene, which uses a modified probasin promoter $\left(\mathrm{ARR}_{2} \mathrm{~PB}\right)$ to drive Cre expression in the prostate epithelium (Wu et al. 2001), although a potential concern is that this Cre allele also drives recombination in the stroma (X Wang and MM Shen, unpubl.). The Pb-Cre4 driver has been used by many laboratories for the conditional deletion of Pten as well as other genes of interest (Wang et al. 2003; Z Chen et al. 2005; Bruxvoort et al. 2007). Another popular Cre driver is the Nkx3.1-Cre knock-in allele, which expresses Cre recombinase specifically in the prostate epithelium, but also in several other tissues during embryogenesis (Stanfel et al. 2006; Lin et al. 2007; Thomsen et al. 2008; Zhang et al. 2008).

Despite much recent progress, current genetically engineered models have several important limitations. First, constitutive conditional gene deletion systems generally result in deletion from early stages of prostate organogenesis, and cannot be initiated in the adult, or in a stochastic manner, as is the case with somatic mutations in human cancer. Thus, the development of an inducible gene targeting system that can be induced in adult prostate epithelium would allow the investigation of gene function in situations where normal prostate organogenesis would not proceed in the absence of the gene of interest. Recent publications have described the generation of tamoxifen-inducible Cre drivers that are likely to be suitable for such approaches (Luchman et al. 2008; Ratnacaram et al. 2008; Birbach et al. 2009; Z Wang et al. 2009). Second, the use of a reversible transgene expression system, such as those driven by a tetracyclineregulated promoter, would allow the modeling of targeted therapeutic interventions on cancer growth, as well as potential acquisition of drug resistance and treatment failure. Such tetracycline-regulated models have been used successfully to investigate oncogene addiction in melanoma and mammary cancer models (Chin et al. 1999; Moody et al. 2002), but have not yet been employed in the prostate. Third, existing Cre drivers to investigate stromal function in prostate carcinogenesis are limited and nonspecific (Jackson et al. 2008), with the best available driver corresponding to the FSP1-Cre transgene (Bhowmick et al. 2004). Fourth, all current prostate cancer models use androgen-dependent promoters to drive the cancer phenotype, either directly or indirectly, and thus are poorly suited to investigate the effects of modulating androgen levels, since androgen deprivation will simultaneously downregulate transgene expression. Finally, at present, there is no autochthonous model that reliably displays bone metastasis, which represents a major limitation in the study of advanced prostate cancer.

Nonetheless, despite their limitations, analyses of genetically engineered mouse models of prostate cancer have significantly advanced our understanding of the molecular pathways of prostate cancer initiation, progression, and castration resistance. Additionally, investigations of genetically engineered mice have led to the identification of biomarkers that can predict disease recurrence, and have provided valuable preclinical resources for investigations of novel therapies and analyses 
Molecular genetics of prostate cancer

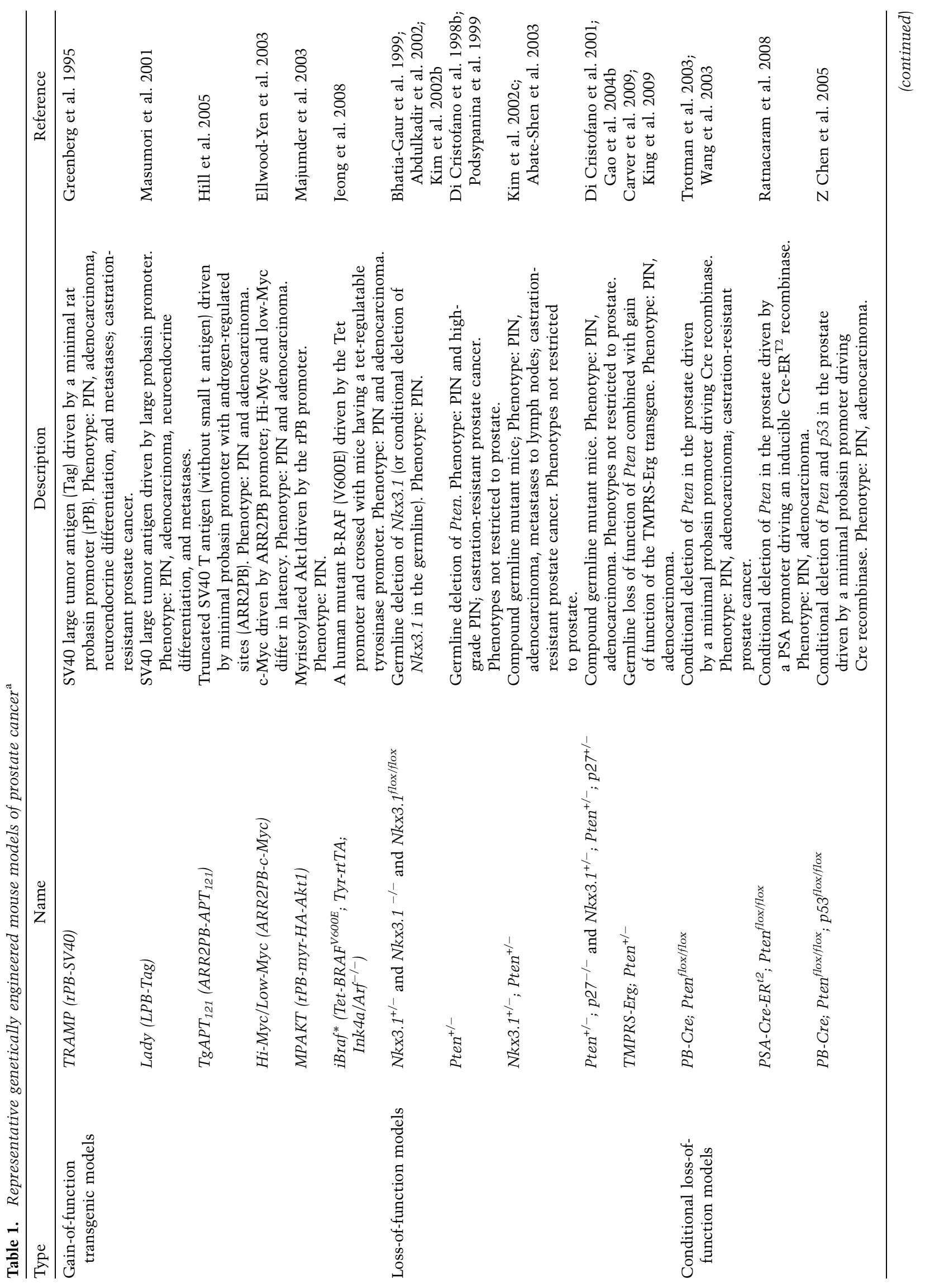




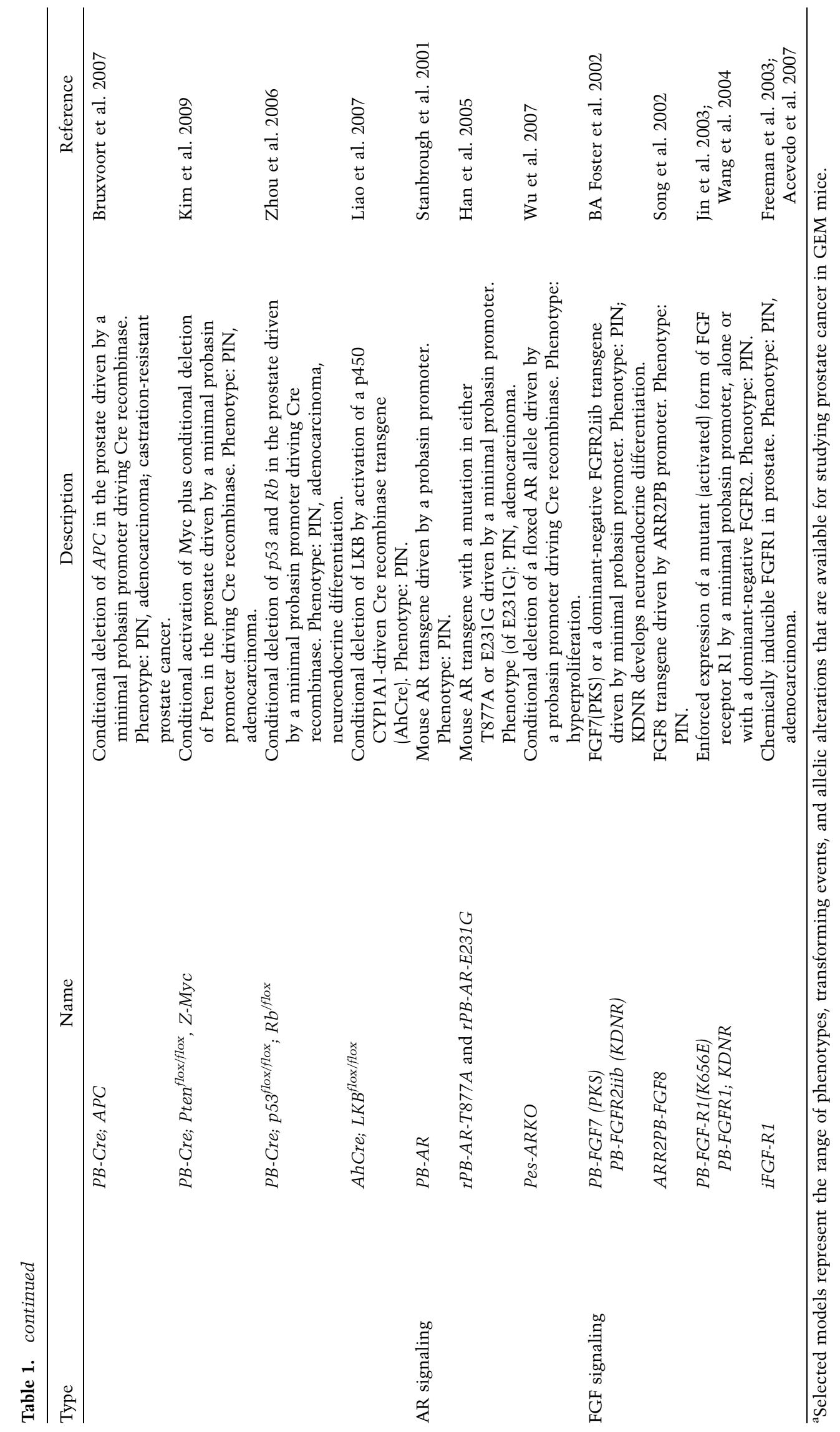


of chemopreventive agents. Examples of each of these applications are described below.

\section{Processes that promote prostate carcinogenesis}

The single most significant risk factor for prostate cancer is advanced age. While men who are younger than 40 have a one in 10,000 chance of developing prostate cancer, this risk increases to one in seven by the age of 60 (American Cancer Society 2009). However, prostate cancer is not simply a by-product of aging, since the incidence varies considerably among different populations. More likely, the relationship of prostate cancer to advanced age likely reflects the interplay of environmental, physiological, and molecular influences with normal consequences of aging that presumably exacerbate the effects of these influences. Moreover, while the precise molecular consequences of aging as they pertain to prostate cancer have not been elucidated, various studies have described gene expression changes associated with aging, particularly in the prostatic stroma, including genes involved in inflammation, oxidative stress, and cellular senescence (Begley et al. 2005; Bavik et al. 2006; Bethel et al. 2009).

Below, we discuss some of the major processes that have been implicated in prostate carcinogenesis (Fig. 1). Perhaps not surprisingly, these are interrelated and involve key regulatory molecules that have been associated with cancer initiation and progression, which will be discussed in the next section.

\section{Inflammation}

Various lines of epidemiological, pathological, and molecular evidence have supported the idea that chronic inflammation is causally linked to prostate carcinogenesis (Haverkamp et al. 2008; Klein and Silverman 2008; Bardia et al. 2009). For example, expression of certain chemokines is a predictor of biochemical disease recurrence in human prostate cancer (Blum et al. 2008). Moreover, administration of the potent heterocyclic amine PhIP (2-amino-1-methyl6-phenyl-imidazo[4,5-b]pyridine), results in chronic inflammation and promotes prostatic hyperplasia and PIN in rodents (Borowsky et al. 2006; Elkahwaji et al. 2007; Nakai et al. 2007; Elkahwaji et al. 2009; Khalili et al. 2010). One of the most well-studied genes involved in protection against carcinogens such as PhIP is GSTP1, which encodes a member of the glutathione S-transferase family that is responsible for detoxification of reactive species, and is epigenetically silenced in a majority of prostate cancers by DNA methylation (Nakayama et al. 2004). Most notably, regions of focal atrophic prostate epithelium can often be identified in aging men, frequently in association with an inflammatory response. Such regions usually display increased epithelial proliferation, and have been termed "proliferative inflammatory atrophy" (PIA) (De Marzo et al. 1999). Regions of PIA are also often located in proximity with PIN and adenocarcinoma, and thus PIA has also been proposed to represent a precursor lesion for prostate cancer (De Marzo et al. 1999, 2003).
These observations have raised interest in the potential causes of prostate inflammation, which may include hormonal perturbations such as altered androgen and estrogen levels, or infection by bacterial or viral agents, physical trauma, or dietary factors (De Marzo et al. 2007b). Indeed, the susceptibility of the prostate gland to infection is known from the incidence of chronic bacterial prostatitis, and a potential role for bacterial infection in prostate carcinogenesis has been suggested by the identification of multiple bacterial species in most prostatectomy samples examined (Sfanos et al. 2008). Interestingly, a recent study has shown that induced bacterial prostatitis in mice can result in histological changes reminiscent of human PIA and down-regulation of expression of the Nkx3.1 homeoprotein (Khalili et al. 2010), while the levels of NKX3.1 expression in human prostate cancer cell lines have been shown to be regulated by inflammatory cytokines (Markowski et al. 2008).

Support for a role for viral infection as contributor to chronic inflammation of the prostate has been provided by studies of rare hereditary prostate cancer (HPC) that have identified several loci associated with increased familial prostate cancer risk (Schaid 2004). Of these loci, HPC1 has been shown to correspond to RNASEL, which encodes 2'-5'-oligoadenylate (2-5A)-dependent RNase L, an endoribonuclease for ssRNA that is a component of the interferon response to viral infection (Carpten et al. 2002). Further studies have shown that the R462Q variant of RNASEL confers decreased protein activity and is associated with increased risk of sporadic prostate cancer (Casey et al. 2002; Xiang et al. 2003), although the relevance of this allele as well as other RNASEL variants for sporadic prostate cancer has been disputed (Wiklund et al. 2004; Li and Tai 2006). Notably, a significant percentage of prostate tumors from patients carrying the variant $R N A S E L$ allele have been reported to contain a novel gammaretrovirus, termed xenotropic murine leukemia virus-related virus (XMRV) (Urisman et al. 2006; Dong et al. 2007), which is expressed in $\sim 20 \%$ of prostate cancer samples, but is not correlated with the presence of the RNASEL R462Q variant (Schlaberg et al. 2009). At present, there is considerable interest in the possibility that XMRV infection may play a role in prostate cancer initiation through stimulation of an inflammatory response, but further studies are required to replicate these initial findings and evaluate a possible causal link (Silverman et al. 2010).

\section{Oxidative stress and DNA damage}

Several lines of evidence have suggested that one of the major aging-associated influences on prostate carcinogenesis is oxidative stress and its cumulative impact on DNA damage (DeWeese et al. 2001; Khandrika et al. 2009; Minelli et al. 2009). Oxidative stress results from the imbalance of reactive oxygen species (ROS) and detoxifying enzymes that control cellular levels of ROS, which leads to cumulative damage to lipids, proteins, and DNA. The prostate appears to be exceptionally vulnerable to oxidative stress, perhaps as a consequence of inflammation, 
hormonal deregulation, diet, and/or epigenetic modifications such as silencing of GSTP1. Evidence linking oxidative stress and prostate cancer initiation include correlative studies showing that major antioxidant enzymes are reduced in human PIN and prostate cancer, together with a coincidental increase in the oxidized DNA adduct 8-oxy7,8,dihydro-2'-deoxyguanosine (8-oxy-dG) (Bostwick et al. 2000). Furthermore, APE/Ref1, a multifunctional enzyme involved in redox control of key enzymes and base excision repair, is up-regulated in prostate cancer, while polymorphisms in the APE gene are associated with increased prostate cancer risk (Kelley et al. 2001; L Chen et al. 2006). Similarly, perturbations in oxidative stress response pathways have been observed in genetically engineered mouse models of prostate cancer coincident with cancer progression (Ouyang et al. 2005; Frohlich et al. 2008). Interestingly, loss of function of the $N k x 3.1$ homeobox gene in the mouse prostate leads to deregulated expression of oxidative damage response genes and increased levels of 8-oxy-dG, correlated with the onset of PIN (Ouyang et al. 2005), while gain of function of the NKX3.1 homeobox gene has also been shown to protect against DNA damage in prostate cancer cell lines (Bowen and Gelmann 2010). Since NKX3.1 is frequently down-regulated in early stages of prostate cancer, its inactivation may contribute to the observed vulnerability of the prostate to oxidative stress as well as to DNA damage associated with cancer initiation.

\section{Telomere shortening}

Another event that has been implicated in prostate cancer initiation is the shortening of telomeres, which is generally associated with DNA damage and may lead to chromosomal instability (Meeker et al. 2002, 2004; Vukovic et al. 2003). Telomere length has been correlated with disease outcome (Fordyce et al. 2005; Joshua et al. 2007), while prostate carcinomas as well as many highgrade PINs display increased telomerase activity, which is not observed in benign prostate tissue (Sommerfeld et al. 1996; Koeneman et al. 1998). These observations suggest that telomere length is actively modulated during prostate cancer progression, but the mechanistic relationships between telomere shortening and cancer initiation, or to induction of cellular senescence (see below), are presently unclear. Nonetheless, various strategies to regulate telomere length are being investigated as potential therapeutic agents (Asai et al. 2003; Chen et al. 2003).

\section{Senescence}

Cellular senescence corresponds to a form of cell cycle arrest in which cells remain fully viable, but are nonproliferative despite exposure to mitogenic signals (Courtois-Cox et al. 2008; d'Adda di Fagagna 2008; Evan and d'Adda di Fagagna 2009). Much recent work has identified cellular senescence as a potent mechanism of tumor suppression that prevents manifestation of the malignant phenotype after oncogenic insults. In particular, activated oncogenes are believed to induce senescence through a variety of molecular mechanisms, including replicative stress or formation of ROS, or as a response to
DNA damage. Thus, oncogene-induced senescence may play a central role in preventing the progression of preneoplastic lesions to the fully malignant state.

In the prostate, cellular senescence has been shown to occur during aging-related prostate enlargement, and has been implicated as a tumor suppressor mechanism for prostate carcinogenesis. Thus, SA- $\beta-$ Gal, a commonly used biomarker of senescence, is frequently detected in $\mathrm{BPH}$ in the human prostate (Choi et al. 2000; Castro et al. 2003). Moreover, other markers of senescence, including $p 14^{a r f}$ and $\mathrm{p} 16^{\text {ink } 4 \mathrm{a}}$, are increased with aging and particularly in nonmalignant cancers, suggesting these may represent markers that distinguish indolent from more aggressive forms of the disease (Zhang et al. 2006). In addition to senescence-related changes observed in epithelial cells, senescent primary prostatic fibroblasts display gene expression signatures associated with oxidative damage and DNA damage, which may in turn influence the invasive behavior of epithelial cells (Bavik et al. 2006). Notably, gene expression changes affecting oxidative damage and DNA damage responses are also observed in prostatic stroma from aged, tumor-prone rats (Bethel et al. 2009), as well as in reactive stroma from human prostate tumors (Dakhova et al. 2009).

Studies in genetically engineered mice have provided mechanistic insights into the role of senescence for prostate tumorigenesis. In particular, complete conditional inactivation of the Pten tumor suppressor gene results in PIN lesions that display a senescence phenotype that can be overcome by inactivation of $p 53$ (Z Chen et al. 2005), but is enhanced in combination with inactivation of the $S k p 2$ E3-ubiquitin ligase (Lin et al. 2010). Based on these findings in mouse models, one possible interpretation for the temporal difference between the occurrence of latent prostate cancer and the appearance of clinical prostate cancer is that cellular senescence may be involved in suppressing progression to aggressive disease, while additional oncogenic events may be required to bypass the senescence mechanism to promote disease progression.

\section{Genomic alterations}

Extensive genomic analyses of prostate cancer have identified copy number alterations and chromosomal rearrangements associated with prostate carcinogenesis. In particular, a number of important somatic alterations have been identified by comparative genomic hybridization (CGH) as gains or losses of chromosomal regions, including gains at $8 \mathrm{q}$ and losses at $3 \mathrm{p}, 8 \mathrm{p}, 10 \mathrm{q}, 13 \mathrm{q}$, and $17 \mathrm{p}$ (Dong 2001; Lapointe et al. 2007; Taylor et al. 2010). Importantly, several of these genetic alterations have also been identified in PIN as well as PIA lesions, which has supported the precursor relationship of these lesions to prostate cancer and has emphasized their relevance for promoting cancer progression. Finally, several key regulatory genes have been mapped to within these chromosomal regions undergoing copy number alterations, including NKX3.1 at 8p21, PTEN at 10q23, and MYC at 8q24. In contrast, however, targeted resequencing studies have suggested that somatic point mutations may be relatively 
infrequent in prostate cancer, with tumor suppressor genes such as TP53 undergoing alterations of copy number instead (Taylor et al. 2010).

\section{Genetic factors}

Extensive efforts have been made to identify genetic susceptibility loci for prostate cancer, both through analyses of hereditary factors associated with familial risk of early-onset disease, and more recently through genome-wide association studies. In particular, prostate cancer susceptibility loci associated with HPC have been mapped to 1q24-25 (HPC1), 17p11 (HPC2), and Xq27-28 (HPCX) (Xu et al. 1998, 2001a,b), which correspond to RNASEL (HPC1), which was discussed above, and $E L A C$ (HPC2), a gene of uncertain function. Additionally, genome-wide association studies have identified numerous single-nucleotide polymorphisms (SNPs) that are associated with cancer risk (Thomas et al. 2008; Eeles et al. 2009; Gudmundsson et al. 2009; Kader et al. 2009). In particular, a major locus identified in these genome-wide association studies is identified by multiple sequence polymorphisms at $8 \mathrm{q} 24$, proximal to $M Y C$, and is discussed below. Disappointingly, however, many of the other loci identified in genome-wide association studies have not been easily replicated in other population-based studies, including analyses of groups with high-risk for prostate cancer, such as African-Americans (Hooker et al. 2010). Finally, studies of individual genetic loci have identified rare sequence polymorphisms associated with increased cancer risk, as has been shown for the C154T polymorphism at the NKX3.1 locus (Gelmann et al. 2002).

\section{Epigenetic alterations}

Epigenetic perturbations are also believed to represent important contributing factors in prostate carcinogenesis, and may provide useful biomarkers for disease progression (Li et al. 2005; Nelson et al. 2007, 2009). For example, DNA methylation has been implicated in silencing genes involved in signal transduction, hormonal response, cell cycle control, and oxidative damage response, such as GSTP1. Furthermore, prostate tumors display global changes in chromatin modification coincident with cancer progression (Kondo et al. 2008; Ke et al. 2009) that presumably result in significant perturbations in the gene expression program of tumor cells. One key modification associated with prostate carcinogenesis is trimethylation of lysine residue 27 of histone $\mathrm{H} 3$ (H3K27-me3), which is mediated by the histone methyltransferase enzyme Ezh2, a key oncogenic driver of advanced disease and metastasis (Varambally et al. 2002). Since the H3K27-me3 mark is associated with transcriptional repression, increased levels in prostate cancer are associated with repression of tumor suppressor genes such as DAB2IP, a member of the Ras GTPase family (H Chen et al. 2005). Global changes in histone modifications are also associated with cellular senescence, through the development of senescenceassociated foci (SAHF), which include epigenetic marks of chromatin silencing (Funayama and Ishikawa 2007). In the future, global analyses of histone modifications by nextgeneration sequencing approaches may provide broad in- sights on the cumulative influences of these modifications for prostate carcinogenesis.

\section{Molecular mechanisms of prostate cancer initiation and progression}

Below, we discuss several molecular events that are believed to occur in a large percentage of prostate carcinomas, focusing on their relationships to key processes discussed in the preceding section (Fig. 1). Although each event has been associated with a possible role in cancer initiation or progression, it is unknown whether there is a temporal sequence associated with these events, or whether there is a causal relationship between them.

\section{NKX3.1 down-regulation}

Down-regulation of the NKX3.1 homeobox gene represents a frequent and critical event in prostate cancer initiation, and is likely to involve multiple mechanisms (Abate-Shen et al. 2008). NKX3.1 is localized within a $150-\mathrm{Mb}$ minimal deleted region of chromosome 8 p21.2 that displays loss-of-heterozygosity (LOH) in up to $85 \%$ of high-grade PIN lesions and adenocarcinomas (Emmert-Buck et al. 1995; Vocke et al. 1996; Haggman et al. 1997; Swalwell et al. 2002; Bethel et al. 2006). However, although $\mathrm{LOH}$ of $8 \mathrm{p} 21$ progressively increases in frequency with cancer grade, the remaining allele of NKX3.1 remains unmutated (Vocke et al. 1996; Voeller et al. 1997; Ornstein et al. 2001; Bethel et al. 2006). In addition, whether or not $8 \mathrm{p} 21 \mathrm{LOH}$ has occurred, there is substantial evidence that $N K X 3.1$ undergoes epigenetic down-regulation, perhaps through promoter methylation (Asatiani et al. 2005). Although earlier studies had suggested that NKX3.1 expression is completely lost in advanced cancers (Bowen et al. 2000), recent analyses using a highly sensitive antibody indicate that low levels of NKX3.1 expression can be demonstrated in nearly all prostate cancers and metastases examined (Gurel et al. 2010). Thus, there appears to be a selection for reduction, but not loss, of NKX3.1 expression throughout prostate cancer progression.

These findings are highly suggestive, since $N k x 3.1$ has been shown to be a critical regulator of prostate epithelial differentiation and stem cell function in mouse models. During development, $N k x 3.1$ is expressed in all epithelial cells of the nascent prostate buds from the urogenital sinus, and represents the earliest known marker for the prostate epithelium (Bhatia-Gaur et al. 1999). In the absence of $N k \times 3.1$, there is a significant decrease in prostatic ductal branching, as well as in production of secretory proteins (Bhatia-Gaur et al. 1999; Schneider et al. 2000; Tanaka et al. 2000). Notably, young adult Nkx3.1 heterozygous and homozygous mutants frequently display prostate epithelial hyperplasia and dysplasia, and often develop intraductal neoplasia (PIN) by 1 year of age (Bhatia-Gaur et al. 1999; Schneider et al. 2000; Tanaka et al. 2000; Abdulkadir et al. 2002; Kim et al. 2002a). These findings are consistent with the tumor suppressor activity of $N K X 3.1$ in cell culture and xenograft assays (Kim et al. 
2002a; Lei et al. 2006). Finally, recent work has shown that $N k x 3.1$ expression in the androgen-deprived prostate marks a rare population of prostate epithelial stem cells that is a cell of origin for prostate cancer in mouse models (Z Wang et al. 2009).

Analyses of $N k x 3.1$ function in human tumor cells and genetically engineered mice have provided insights into its potential roles in cancer initiation. In particular, $N k x 3.1$ inactivation in mice results in a defective response to oxidative damage, while its expression in human prostate cancer cell lines protects against DNA damage and is regulated by inflammation (Ouyang et al. 2005; Markowski et al. 2008; Bowen and Gelmann 2010). A causal role for $N k x 3.1$ in these processes has been suggested by analyses of genes that are dysregulated following perturbation of Nkx3.1 expression in mouse models or human cell lines (Magee et al. 2003; Ouyang et al. 2005; Muhlbradt et al. 2009; Song et al. 2009). These and other findings have led to a model in which $N K X 3.1$ represents a haploinsufficient tumor suppressor gene that acts as a "gatekeeper" gene for prostate cancer initiation (Kim et al. 2002a; Gelmann 2003; Magee et al. 2003).

\section{Myc up-regulation}

It has long been known that the 8q24 chromosomal region encompassing the $M Y C$ oncogene is somatically amplified in a subset of advanced prostate tumors (Jenkins et al. 1997; Sato et al. 1999/. However, recent studies have suggested a role for MYC overexpression in cancer initiation, as nuclear MYC protein is up-regulated in many PIN lesions and the majority of carcinomas in the absence of gene amplification (Gurel et al. 2008). These findings may be consistent with the identification of a major susceptibility locus at 8q24 in several large-scale genome-wide association studies of prostate cancer as well as other epithelial cancers (Amundadottir et al. 2006; Freedman et al. 2006; Gudmundsson et al. 2007, 2009; Haiman et al. 2007; Yeager et al. 2007, 2009; Al Olama et al. 2009). Multiple SNPs associated with prostate cancer risk alleles are clustered within three independent regions of a genepoor genomic locus spanning $\sim 1.2 \mathrm{Mb}$ between FAM $84 B$ and $M Y C$, with $M Y C$ located $\sim 250 \mathrm{~kb}$ away from the closest SNP marker. Detailed analyses have not yet revealed any correlation between risk alleles and $M Y C$ RNA expression levels in prostate tumor samples, or the presence of any non-protein-coding genes such as microRNAs (miRNAs) (Pomerantz et al. 2009). Nonetheless, long-range regulatory elements for $M Y C$ have been identified recently in this region, raising the possibility that the risk alleles may alter the regulation of MYC expression (Jia et al. 2009; Sotelo et al. 2010). Interestingly, another recent study has found that the X-linked gene FOXP3 encodes a winged helix transcription factor that represses $M Y C$ expression (although apparently not through distant enhancer-binding sites), and itself is mutated in prostate cancer (L Wang et al. 2009).

At the functional level, transgenic mice overexpressing human MYC display rapid formation of PIN followed by progression to invasive adenocarcinoma with rare metastases (Ellwood-Yen et al. 2003), while forced expression of
MYC is sufficient to immortalize nontumorigenenic human prostate epithelial cells (Gil et al. 2005). Interestingly, bioinformatic analyses identified an expression signature characterized by down-regulation of $N k x 3.1$ and up-regulation of Pim1, which is known to collaborate with Myc in lymphomas (Ellwood-Yen et al. 2003). Consistent with these data, lentiviral coexpression of human MYC with mouse Pim1 in tissue recombinants results in cooperative formation of carcinomas with neuroendocrine differentiation (Wang et al. 2010).

\section{TMPRSS2-ERG translocations}

Important recent studies have identified chromosomal rearrangements that activate members of the ETS family of transcription factors (ERG, ETV1, and ETV4) in the majority of prostate carcinomas (Tomlins et al. 2005, 2007a; Iljin et al. 2006; Mehra et al. 2007b; Mosquera et al. 2007; Hu et al. 2008; Rouzier et al. 2008; Saramaki et al. 2008). The most common of these rearrangements creates a TMPRSS2-ERG fusion gene, resulting in expression of $\mathrm{N}$-terminally truncated ERG protein under the control of the androgen-responsive promoter of TMPRSS2 (Tomlins et al. 2005; Iljin et al. 2006; Perner et al. 2006; J Wang et al. 2006; Clark et al. 2007). As TMPRSS2 and ERG are located $\sim 3 \mathrm{Mb}$ apart on chromosome $21 \mathrm{q}$, this rearrangement occurs through either an interstitial deletion, which is more common, or an unbalanced interchromosomal translocation (Iljin et al. 2006; Perner et al. 2006). The frequency of these TMPRSS2-ERG fusions is $\sim 15 \%$ in high-grade PIN lesions, and $\sim 50 \%$ in localized prostate cancer (Clark et al. 2008; Mosquera et al. 2008; Albadine et al. 2009), suggesting that this rearrangement either occurs after cancer initiation, or alternatively corresponds to an early event that predisposes to clinical progression. Interestingly, formation of these chromosomal rearrangements may be an indirect consequence of AR function, as studies in androgen-responsive $\mathrm{LNCaP}$ cells have shown that AR binding induces chromosomal proximity between the TMPRSS2 and ERG loci that can lead to formation of TMPRSS2-ERG fusions following DNA damage (Lin et al. 2009; Mani et al. 2009). In addition, androgen signaling can recruit topoisomerase II to AR-binding sites, leading to induction of double-stranded breaks even in the absence of genotoxic stress (Haffner et al. 2010).

Despite the prevalence of these genomic rearrangements, the functional significance of the TMPRSS2-ERG fusion and other ETS rearrangements in prostate cancer is still not fully resolved. Recent whole-genome chromatin immunoprecipitation analyses have shown that ERG can bind to AR downsteam target genes and disrupts $A R$ signaling in prostate cancer cells through epigenetic silencing, consistent with a role in inhibiting prostate epithelial differentiation ( $\mathrm{Yu}$ et al. 2010). Furthermore, analyses of ETS gene activation in cell culture assays as well as transgenic mice have suggested that ETS activation promotes EMT and tumor-invasive properties (Tomlins et al. 2007a, 2008a; Klezovitch et al. 2008; J Wang et al. 2008), although the effects are relatively moderate. In transgenic mice, expression of truncated human ERG transgenes results in a minimal or weak PIN phenotype 
(Tomlins et al. 2007a, 2008a; Klezovitch et al. 2008). However, expression of truncated $E R G$ synergizes with loss of Pten to result in high-grade PIN and carcinoma in mice (Carver et al. 2009; King et al. 2009). In addition, recent findings suggest that TMPRSS2-ERG-positive tumors are also associated with the deletion of a small genomic region on 3p14, suggestive of another cooperative interaction in tumorigenesis (Taylor et al. 2010). Taken together, these findings suggest that ETS rearrangements are selected primarily for their ability to disrupt differentiation programs and/or to promote prostate cancer progression through cooperative interactions with other transforming events.

\section{PTEN}

PTEN was originally identified as a tumor suppressor that is frequently mutated or deleted in many cancers, including prostate (Salmena et al. 2008). The relevance of PTEN loss for prostate cancer was initially inferred from its location on chromosomal region 10q23, which frequently undergoes allelic loss in prostate cancer, as well as by its reduction or loss of expression in prostate tumors (Wang et al. 1998; Whang et al. 1998; McMenamin et al. 1999; Dong et al. 2007). Earlier studies had generated conflicting data regarding whether both alleles of PTEN are deleted in prostate cancer, or, if one allele is deleted, whether the remaining allele is mutated, or if the expression of PTEN protein is reduced, inactivated, or altered in subcellular localization. To resolve these issues, recent studies have investigated PTEN copy number, mutational status, and/or protein expression in primary or castrationresistant tumors using multiple experimental approaches (Verhagen et al. 2006; Schmitz et al. 2007; Sircar et al. 2009; Taylor et al. 2010). In combination with the consensus of previous reports, these studies support the conclusion that PTEN undergoes copy number loss as an early event in prostate carcinogenesis, and is correlated with progression to aggressive, castration-resistant disease. Interestingly, these studies have also suggested that low levels of PTEN activity may be retained in prostate cancer-an observation that parallels the haploinsufficiency of NKX3.1 and the $p 27$ cell cycle regulator (Gao et al. 2004a; Abate-Shen et al. 2008), and which may reflect the relative indolence of prostate tumors.

Analyses of Pten deletion in genetically engineered mouse models have uncovered its cooperativity with inactivation of other key genes that are deregulated in prostate tumorigenesis, and have also provided insights into new therapeutic options for the treatment of prostate cancer. Germline loss of Pten in heterozygous mutants or conditional deletion in the prostate epithelium results in PIN and/or adenocarcinoma (Di Cristofano et al. 1998a; Podsypanina et al. 1999; Trotman et al. 2003; Wang et al. 2003). Inactivation of Pten has been shown to cooperate with loss of function of the Nkx3.1 homeobox gene, upregulation of the $c-M y c$ proto-oncogene, or the TMPRSSERG fusion (Kim et al. 2002c, 2009; Carver et al. 2009; King et al. 2009). Additionally, investigations of Pten loss-together with perturbations of cell cycle regulators such as $p 27, p 18^{\text {ink4c }}$, and $p 14^{a r f}$ (Di Cristofano et al. 2001; Bai et al. 2006; Z Chen et al. 2009), or components of key signaling pathways such as Rheb, TSC2, and Rictor (L Ma et al. 2005; Nardella et al. 2008; Guertin et al. 2009)-have further emphasized the significance of haploinsufficiency in prostate cancer. Interestingly, the requirement of the mTORC2 complex as well as the p110 $\beta$ isoform of PI3K for tumor formation following Pten loss suggests that these signaling components may provide additional and/ or alternative targets for therapeutic intervention (Jia et al. 2008; Guertin et al. 2009). Moreover, the observation that complete inactivation of Pten in mouse prostate tumors leads to cellular senescence (Z Chen et al. 2005) has led to the idea that novel therapeutic approaches might promote senescence for selective targeting of prostate tumor cells through knockdown of Pten function (Alimonti et al. 2010) or targeting of $S k p 2$ (Lin et al. 2010). Notably, PTEN reduction or loss in prostate cancer predisposes to the emergence of castration-resistant prostate cancer (Mulholland et al. 2006; Shen and Abate-Shen 2007). In particular, perturbation of PTEN expression in human prostate cancer cell lines or targeted deletion of Pten in mouse prostate cancers is sufficient for the development of castration resistance (Lin et al. 2004; Bertram et al. 2006; Gao et al. 2006b; Wu et al. 2006). While this may reflect the ability of PTEN to interact directly with AR, the mechanistic details by which PTEN loss promotes castration resistance remain to be resolved.

\section{Signaling pathways-Akt/mTOR and MAPK signaling}

As noted above, considerable evidence indicates that Pten loss of function results in up-regulation of the Akt/mTOR signaling pathway in prostate cancer, primarily through activation of Akt1 (Thomas et al. 2004; ML Chen et al. 2006; Mulholland et al. 2006; Shen and Abate-Shen 2007). Up-regulation of this pathway in prostate cancer can also take place through activating mutations of Akt1 (Boormans et al. 2008), or through activation of the $\mathrm{p} 110 \beta$ isoform of PI3K (Hill et al. 2010; Lee et al. 2010). The functional consequences of Akt/mTOR pathway activation are particularly relevant for castration-resistant prostate cancer, as has been shown in genetically engineered mouse models, in gain-of-function studies with orthotopic grafting or tissue recombination models, as well as in human cell lines (Majumder et al. 2003; Uzgare and Isaacs 2004; Gao et al. 2006a; Xin et al. 2006). Activation of Akt occurs primarily at the cell membrane, and is consequently sensitive to levels of cholesterol in prostate cancer cells (Zhuang et al. 2005; Adam et al. 2007); however, Akt has additional functions in the nucleus that are dependent on the levels of PML (Trotman et al. 2006). The consequences of Akt activation are mediated in part by activation of NF- $\mathrm{BB}$ signaling via stimulation of IKK (Dan et al. 2008). Conversely, functional studies in mouse models and correlative studies in human prostate cancer have implicated deregulated NF- $\mathrm{KB}$ signaling in mediating androgen responsivity, metastasis, and disease outcome (Fradet et al. 2004; Ismail et al. 2004; Lessard et al. 2006; Luo et al. 2007; Zhang et al. 2009). 
In addition to Akt/mTOR signaling, Erk (p42/44) MAPK signaling is also frequently activated in prostate cancer, particularly in advanced disease, and is often coordinately deregulated together with Akt signaling (Abreu-Martin et al. 1999; Gioeli et al. 1999; Paweletz et al. 2001; Malik et al. 2002; Thomas et al. 2004; Kinkade et al. 2008). Simultaneous activation of these signaling pathways promotes tumor progression and castration resistance in prostate cancer cell lines and mouse models (Uzgare and Isaacs 2004; Gao et al. 2006a), while combinatorial inhibition of these pathways inhibits castrationresistant prostate cancer in genetically engineered mice (Kinkade et al. 2008). In contrast with Akt/mTOR signaling, the upstream events that lead to activation of Erk MAPK signaling are less well defined, but are thought to be linked to aberrant growth factor signaling (Gioeli 2005). Although mutations of $R A S$ or $R A F$ are rarely found in human prostate cancer, the pathway is frequently perturbed in advanced prostate cancers (Taylor et al. 2010). Notably, expression of activated forms of either Raf or Ras in the mouse prostrate epithelium results in MAPK activation and promotes cancer formation (Jeong et al. 2008; Pearson et al. 2009). Interestingly, a small percentage of aggressive prostate tumors contains a translocation of $B-R A F$ or $C-R A F$ that results in activation (Palanisamy et al. 2010), suggesting that perturbations of Ras or Raf signaling may occur in prostate cancer through mechanisms other than activating mutations.

\section{Oncogenic tyrosine kinases}

The deregulated expression of oncogenic tyrosine kinases has been studied extensively in many cancers, since these can represent targets for therapeutic intervention (Gschwind et al. 2004). In prostate cancer, aberrant tyrosine kinase signaling, particularly through Her2/ $\mathrm{Neu}$ or SRC tyrosine kinases, has been implicated in aggressive disease, progression to metastasis, and castration resistance, and, consequently, has been implicated as a key therapeutic target in patients with advanced disease (Mellinghoff et al. 2004; Fizazi 2007). In particular, stimulation of AR signaling leads to activation of $S R C$ in prostate cancer cells, which can lead to phosphorylation of AR, castration resistance, and cellular proliferation and invasiveness (Migliaccio et al. 2000; Agoulnik et al. 2005; Kraus et al. 2006). However, most functional analyses of $S R C$ and other oncogenic tyrosine kinases have been limited to studies of prostate cancer cell lines in culture or in xenografts, and further insights will require analyses of in vivo models and correlative studies of clinical specimens.

\section{Developmental signaling pathways}

Molecular analyses of prostate development are likely to be informative for prostate carcinogenesis, as recent studies have shown that prostate tumors express a wide range of genes normally expressed during embryonic/ neonatal organogenesis, suggesting that cancer progression reactivates embryonic developmental programs of gene expression (Schaeffer et al. 2008; Pritchard et al.
2009). In particular, elevated canonical Wnt signaling may play a role in the emergence of castration resistance (G Wang et al. 2008), while prostate cancer in mice can result from inactivation of $A p c$ or overexpression of a constitutively active $\beta$-catenin together with activated K-ras (Bruxvoort et al. 2007; Pearson et al. 2009; Yu et al. 2009). In contrast, however, evidence from human tumors suggests that nuclear localization of $\beta$-catenin is inversely correlated with tumor progression (Horvath et al. 2005; Whitaker et al. 2008), suggesting that canonical Wnt signaling may not play a significant role in prostate cancer progression. With respect to the Hedgehog pathway, although there is considerable evidence that activation of Hedgehog signaling plays a significant role in prostate cancer progression, it remains unclear as to whether this occurs through an autocrine mechanism in epithelial cells (Karhadkar et al. 2004; Sanchez et al. 2004), or, alternatively, through paracrine signaling involving stromal components (Yauch et al. 2008; Shaw et al. 2009). Finally, paracrine FGF signaling has also been implicated in prostate cancer in mouse models, through either epithelial activation of FGFR1 or stromal overexpression of FGF10 (Acevedo et al. 2007; Memarzadeh et al. 2007). This up-regulation of FGF signaling may provide a mechanism for the activation of Erk MAPK pathway activity observed in prostate cancer progression.

\section{Ezh2}

The Polycomb group gene EZH2 encodes a histone lysine methyltransferase that is frequently up-regulated in advanced prostate cancer, in some cases through gene amplification (Varambally et al. 2002; Saramaki et al. 2006), and is associated with aggressive tumors (Bachmann et al. 2006). EZH2 expression is negatively regulated by miR-101, and miR-101 expression decreases during cancer progression, concomitant with somatic loss of one or both miR-101 alleles (Zhao et al. 2007). Among the targets of EZH2 is NKX3.1, which is repressed via expression of ERG and is dependent on $\mathrm{H} 3 \mathrm{~K} 27$ trimethylation (Kunderfranco et al. 2010). Other EZH2 target genes in prostate cancer are associated specifically with metastasis, including E-cadherin (Cao et al. 2008) and DAB2IP (H Chen et al. 2005), which promotes prostate cancer metastasis through activation of Ras and NF-kB pathways (Min et al. 2010). However, Ezh2 has also been shown to function in the cytoplasm to control actin polymerization in prostate and nonprostate cells (Su et al. 2005; Bryant et al. 2008), and therefore analyses of target genes may not fully explain $E Z H 2$ function in cancer progression.

\section{miRNAs}

miRNAs regulate normal processes of growth and development as well as pathogenic processes associated with cancer, and analyses of their expression patterns have been effective for stratifying human cancers (Lu et al. 2005; Volinia et al. 2006). Expression profiling studies of human prostate tumors and xenografts have suggested that the expression patterns of miRNAs may distinguish indolent from aggressive tumors (Porkka et al. 
2007; Ambs et al. 2008; Ozen et al. 2008; Coppola et al. 2009; DeVere White et al. 2009), and have implicated specific miRNAs in castration-resistant prostate cancer (Shi et al. 2007; Sun et al. 2009). Consistent with these findings, key enzymatic components of miRNA synthesis and processing such as Dicer are up-regulated during prostate tumor progression (Chiosea et al. 2006; Ambs et al. 2008; Poliseno et al. 2010a), while functional analyses of mice with conditional deletion of Dicer support a role for miRNAs in prostate epithelial proliferation (Zhang et al. 2010). Furthermore, miRNAs have specific roles in regulation of critical target genes, as the cluster miR-106b-25 negatively regulates PTEN expression (Poliseno et al. 2010a), while genomic loss of miR-101 leads to up-regulation of EZH2 in prostate cancer progression (Varambally et al. 2008). In addition, functional analyses of the miR-15a-miR-16-1 cluster in regulating expression of CCND1, WNT3A, and BCL2 in prostate cancer have provided an example of potential therapeutic benefit in restoring expression of miRNAs (Bonci et al. 2008), while detection of miRNAs in human plasma has been proposed as a platform for blood-based detection of human cancer (Mitchell et al. 2008). Notably, a recent study has shown that the expressed pseudogene PTENP1 can regulate the expression of PTEN in prostate cancer by competing for miRNA binding (Poliseno et al. 2010b), demonstrating a new mechanism for regulating gene expression in human tumors.

\section{AR function and castration resistance}

\section{$A R$ and the emergence of castration resistance}

$\mathrm{AR}$ is a nuclear hormone receptor whose signaling plays a key role in both normal prostate development and prostate cancer. The most abundant androgen is testos- terone, which is synthesized by the testis and converted into the more active metabolite dihydrotestosterone in prostate tissue through the activity of 5a-reductase. In addition, the adrenal gland synthesizes minor androgen species, including androstenedione and dehydroepiandrosterone (DHEA), which can be converted into testosterone. In human patients, androgen deprivation therapy is usually performed by administration of gonadotropin-releasing hormone analogs and/or surgical castration (orchiectomy), often in combination with anti-androgens such as flutamide or bicalutamide.

Following androgen deprivation, the androgen dependence of prostate tissue is manifested by rapid cellular apoptosis and involution to the regressed state (Fig. 3). In culture, however, androgen-dependent prostate cell lines cease proliferation when androgens are removed, but do not undergo apoptosis (Watson et al. 2005; Gao et al. 2006a). In contrast, in tissue reconstitution experiments, the same prostate cell lines will display apoptosis following androgen deprivation, indicating that the apoptotic response is induced by stromal tissue (Gao et al. 2006a). These findings are consistent with earlier tissue reconstitution experiments that analyzed recombination of AR-null mutant epithelium with wild-type stroma (Kurita et al. 2001). Thus, androgen dependence of prostate epithelium in vivo requires paracrine activity of stromal $A R$, similar to the requirement for mesenchymal AR in epithelial-mesenchymal interactions during early prostate organogenesis (Shen and Abate-Shen 2007). Consistent with this conclusion, conditional deletion of AR in both epithelium and stroma of TRAMP mice resulted in smaller tumors with decreased proliferation relative to those formed after epithelial-specific AR deletion (Niu et al. 2008b).

In normal prostate epithelium, AR suppresses cellular proliferation, as probasin-Cre-mediated conditional deletion of AR leads to increased proliferation accompanied

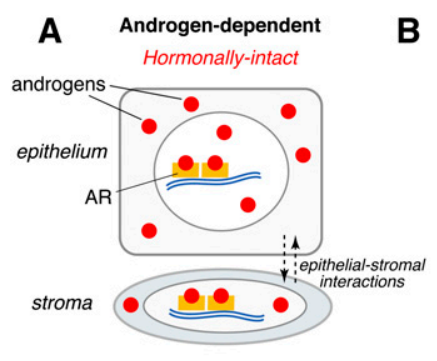

Normal homeostasis

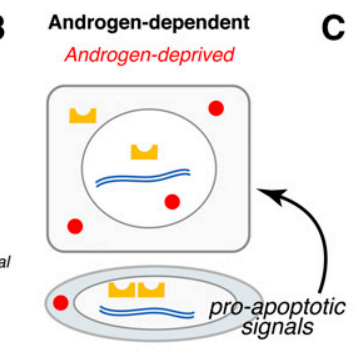

Apoptosis

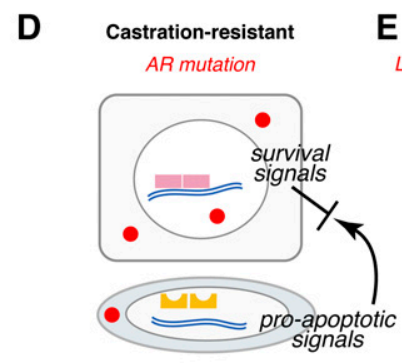

Survival/proliferation

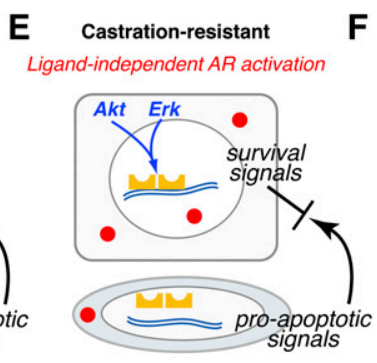

Survival/proliferation

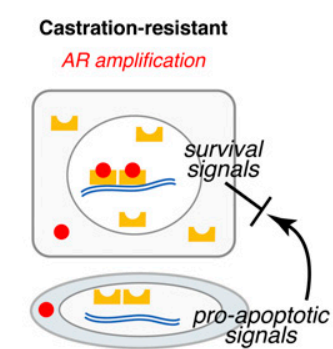

Survival/proliferation

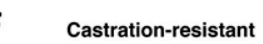
Endogenous androgen synthesis

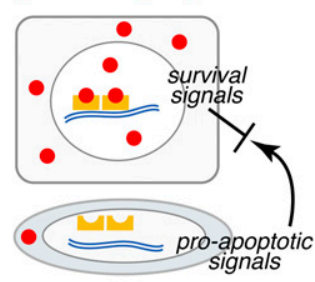

Survival/proliferation
Figure 3. Role of AR in castration-resistant prostate cancer. (A) AR maintains homeostasis of both epithelial and stromal tissues in the normal prostate. $(B)$ Following androgen ablation, stromal cells produce paracrine proapoptotic signals that act on neighboring epithelial cells, promoting regression of normal prostate. $(C-F)$ Castration resistance can occur through a variety of molecular mechanisms, including $\mathrm{AR}$ amplification $(C)$; gain-of-function mutation of AR mutation $(D)$; ligand-independent AR activation by up-regulation of other signaling pathways, such as the Akt/mTOR and Erk MAPK pathways $(E)$; or endogenous biosynthesis of androgens by tumor cells $(F)$. Adapted from Shen and Abate-Shen (2007); (C) 2007 American Association for Cancer Research. 
by decreased expression of differentiation markers (Wu et al. 2007). In prostate cancer, however, AR suppresses proliferation of basal cells, supports survival of luminal cells, and promotes metastasis, as shown by analyses of AR conditional deletion in the context of the TRAMP model (Niu et al. 2008a). This complex loss-of-function phenotype contrasts with more straightforward gain-of-function studies, as transgenic mice overexpressing wild-type $A R$ under the control of the probasin promoter develop PIN (Stanbrough et al. 2001), while overexpression of an AR missense mutation results in prostate cancer (Han et al. 2005). Overall, it appears that AR is likely to play different cell type-specific roles in both normal and cancer cells, which are modulated by interactions with other key regulators of prostate epithelial fate. For example, Nkx3.1 negatively regulates AR transcription and signaling activity (Lei et al. 2006), while genomic analyses of AR enhancerbinding sites reveal likely interactions with $\mathrm{Nkx} 3.1$ and FoxAl, another key transcriptional regulator of prostate epithelial differentiation (Gao et al. 2005; He et al. 2010).

\section{Retention of $A R$ signaling in castration resistance}

Even when prostate cancer progresses to castration resistance, AR activation and signaling remains sustained through a variety of mechanisms (Fig. 3; Taplin and Balk 2004; Attard et al. 2009a; Bonkhoff and Berges 2010). Notably, castration-resistant tumors express AR as well as AR target genes such as PSA, indicating that pathway activity is intact (Gregory et al. 1998). These findings have been most strongly supported by key experiments showing that xenografts that have been selected for castration resistance primarily differ from their parental androgen-dependent lines with respect to levels of AR expression (Chen et al. 2004). Thus, androgen signaling switches from a paracrine mechanism involving the stroma in androgen-dependent cells to an autocrine mechanism in castration resistance (Gao et al. 2001).

Several molecular mechanisms have been described for the ability of AR to retain signaling activity in castrationresistant prostate cancer. These mechanisms include the amplification of AR gene copy number in approximately one-third of castration-resistant carcinomas (Visakorpi et al. 1995; Koivisto et al. 1997; Linja et al. 2001). Another $10 \%-30 \%$ of tumors have gain-of-function mutations of AR that may confer increased protein stability, greater sensitivity to androgens, novel responses to other steroid hormones, ligand-independent activity, or increased recruitment of AR coactivator proteins (Taplin et al. 1995, 2003; Zhao et al. 2000; Robzyk et al. 2007; Brooke et al. 2008; Steinkamp et al. 2009). In addition, recent studies have shown that expression of alternative splice isoforms encoding constitutively active AR variants also occurs in castration-resistant cancer (Dehm et al. 2008; Guo et al. 2009; Hu et al. 2009). Finally, an unusual mechanism for increased AR signaling activity is the endogenous expression of androgen synthetic enzymes by tumor tissue, which can lead to de novo androgen synthesis or conversion of weaker adrenal androgens into testosterone and dihydrotestosterone (Titus et al. 2005; Stanbrough et al. 2006; Locke et al. 2008; Montgomery et al. 2008).
Ligand-independent activation of AR activity can also take place through activation of growth factor signaling pathways. Notably, up-regulation of the PI3K pathway through Pten deletion appears to be particularly effective, as PIN lesions in Nkx3.1; Pten double-mutant mice display castration resistance prior to carcinoma formation (Gao et al. 2006b). Furthermore, analysis of androgendependent cell lines in tissue reconstitution assays has shown that castration resistance can be induced by activation of the PI3K pathway, and is synergistically enhanced by up-regulation of MAPK signaling, but remains dependent on AR function (Gao et al. 2006a; Jiao et al. 2007). At the molecular level, growth factor signaling can up-regulate AR transcriptional activity through increased tyrosine phosphorylation, or perhaps elevated ubiquitination of AR (Guo et al. 2006; Xu et al. 2009).

Finally, castration resistance can be enhanced through an increased inflammatory response. For example, production of interleukin- $1 \beta$ by infiltrating macrophages can lead to derepression of the AR corepressor complex in prostate tumor cells, thereby converting AR antagonists into agonists (Zhu et al. 2006). In addition, production of inflammatory cytokines by B lymphocytes can lead to nuclear translocation of IKK $\alpha$ and castration resistance in mouse prostate tumor cells and allografts (Luo et al. 2007). Moreover, analyses of TRAMP mice and cell lines have shown that nuclear IKK $\alpha$ can enhance prostate cancer metastasis through down-regulation of Maspin (Luo et al. 2007). Consequently, the emergence of castration resistance and metastasis may be coordinately linked at the molecular level through interactions with the tumor microenvironment.

Overall, these findings suggest that AR target genes and regulatory networks should be similar in androgendependent and castration-resistant prostate cancer. This conclusion has been supported by expression profiling of tumors with and without neoadjuvant androgen ablation prior to radical prostatectomy, which showed that castration-resistant tumors displayed up-regulation of AR, androgen synthetic enzymes, and known AR target genes (Holzbeierlein et al. 2004). However, recent genomic chromatin immunoprecipitation studies have shown that AR activity in castration-resistant prostate cancer is not identical to that displayed by AR in androgen-dependent cells. In particular, there is a significant alteration of genomic AR-binding targets and associated epigenetic chromatin marks in castration-resistant prostate cancer cell lines, resulting in up-regulation of M-phase-associated cell cycle genes (Q Wang et al. 2009). These findings suggest that AR-interacting proteins and/or histone-modifying enzymes may play a significant role in mediating castration resistance.

At present, it is unclear when castration resistance normally arises within prostate tumors. The conventional "adaptation" model proposes that castration-resistant cells arise through genetic/epigenetic conversion of previously androgen-dependent cells during conditions of androgen deprivation, while the alternative "clonal selection" model suggests that emergence of castration resistance reflects the proliferation of a previously quiescent 
population of rare castration-resistant cells within an otherwise androgen-dependent tumor (Isaacs and Coffey 1981). Although the former model represents the prevailing view, evidence for the latter model has been provided in studies of the onset of castration resistance in TRAMP mice (Gingrich et al. 1997), as well as through limiting dilution and fluctuation analyses of an androgen-dependent xenograft (Craft et al. 1999a). In addition, analysis of localized human prostate tumors suggests that rare AR mutations can be detected prior to androgen deprivation therapy (Gaddipati et al. 1994; Tilley et al. 1996; Bergerat and Ceraline 2009). Furthermore, the finding that castration-resistant cells such as CARNs (castration-resistant Nkx3.1-expressing cells) represent a cell of origin for prostate cancer also favors a clonal selection model (X Wang et al. 2009) in which the rare castration-resistant population might also correspond to putative cancer stem cells. Thus, while some mechanisms of castration resistance may represent an adaptive response to androgen deprivation therapy, in many cases, increased AR activity may be selected prior to treatment during prostate cancer progression.

\section{Prostate stem cells and tumor-initiating cells (TICs)}

\section{Localization of adult stem cells}

A tissue stem cell can be defined as a progenitor that is multipotent, being capable of giving rise to distinct cell types of the tissue of interest, and also able to self-renew by maintaining the stem cell phenotype in progeny following cell division (Rossi et al. 2008). In the case of the adult prostate, the existence of epithelial stem cells is implied by the ability of the adult prostate to undergo repeated cycles of extensive regression in response to androgen deprivation, followed by full regeneration following androgen restoration. Consequently, the prostate epithelium should contain a long-term resident pool of stem cells that are castrationresistant (Isaacs 1985). Notably, the majority of luminal cells are androgen-dependent and undergo apoptosis following castration, while most basal and neuroendocrine cells survive and are castration-resistant (English et al. 1987; Evans and Chandler 1987).

Most studies of prostate epithelial stem cells have relied on flow cytometry to purify subsets of epithelial cells based on cell surface marker expression, and have explored their progenitor potential in cell culture or transplantation assays (Lawson and Witte 2007; Kasper 2008). In particular, subpopulations of prostate basal cells isolated using cell surface markers can display bipotentiality and self-renewal in cell culture as well as tissue reconstitution assays (Richardson et al. 2004; Burger et al. 2005; Xin et al. 2005; Lawson et al. 2007; Goldstein et al. 2008). For example, isolation of a $\mathrm{Lin}^{-} \mathrm{Sca}-\mathrm{I}^{+} \mathrm{CD} 49 \mathrm{f}^{+}$ population results in a 60 -fold enrichment for stem cells (Lawson et al. 2007). Further enrichment can be obtained using the Trop2 marker, which also allows isolation of a stem cell-enriched $\mathrm{Lin}^{-} \mathrm{CD} 4 \mathrm{f}^{+} \mathrm{Trop}^{+}{ }^{+}$fraction from human prostate epithelium (Goldstein et al. 2008). In independent studies, $\alpha_{2} \beta_{1}$ integrin ${ }^{\text {hi }} \mathrm{CD} 133^{+}$basal cells also correspond to an enriched stem cell fraction in human prostate epithelium (Richardson et al. 2004). Finally, single $\mathrm{Lin}^{-} \mathrm{Sca}-1^{+} \mathrm{CD} 133^{+} \mathrm{CD} 44^{+} \mathrm{CD} 117^{+}$cells, which are predominantly basal in mice and are exclusively basal in humans, have been reported to reconstitute prostatic ducts in renal grafts (Leong et al. 2008).

In contrast, other data have supported a luminal localization of prostate epithelial stem cells, primarily with respect to prostate regeneration. In particular, analyses of grafted tissue from $p 63$-null mice have demonstrated the formation and serial regression/regeneration of prostate tissue in the absence of basal cells (Kurita et al. 2004). Furthermore, recent studies have identified a rare luminal population of CARNs in the regressed prostate epithelium that displays stem cell properties during prostate regeneration (X Wang et al. 2009). In particular, in vivo genetic lineage marking showed that CARNs display bipotentiality and long-term self-renewal during prostate regeneration, and are also capable of reconstituting prostatic ducts following single-cell transplantation.

At present, it is difficult to ascertain the potential overlap as well as lineage relationships of the various candidate stem cells that have been identified, in part due to the distinct methodologies and assays employed (Fig. 4). In addition, individual cell surface markers may lack specificity for stem/progenitor cells, as has been
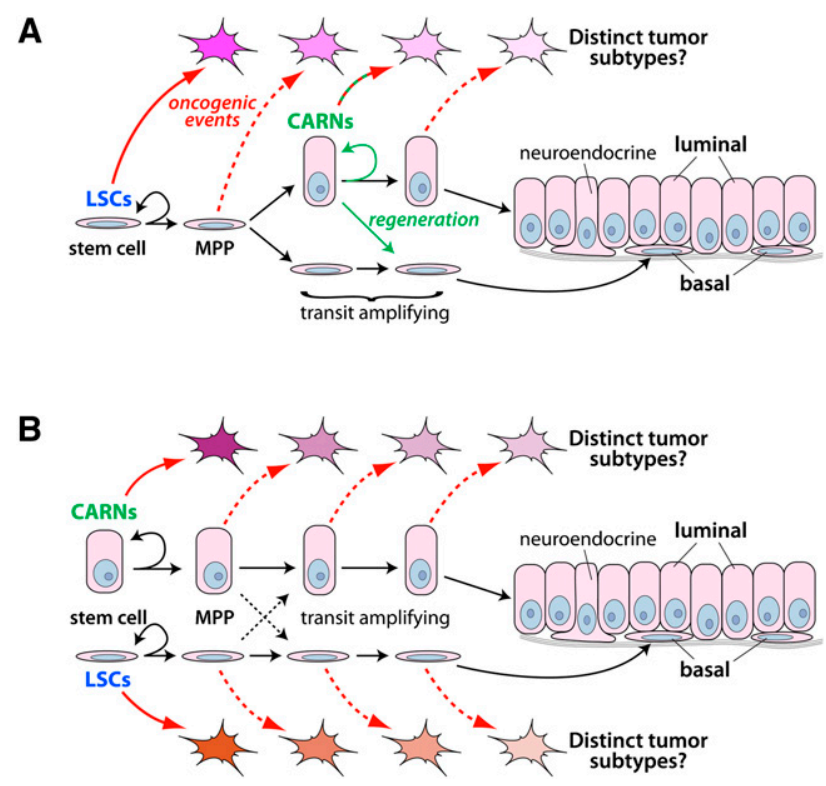

Figure 4. Lineage hierarchy in the prostate epithelium and the cell of origin for prostate cancer. Two possible lineage relationships for the adult prostate epithelium are shown, together with the potential roles of $\mathrm{Lin}^{-} \mathrm{Sca}-1^{+} \mathrm{CD} 49 \mathrm{f}^{+}$cells (LSCs) and CARNs. Different cell types of origin in the lineage hierarchy might then generate distinct tumor subtypes following oncogenic transformation (red arrows). (A) In this model, LSCs correspond to stem cells, and CARNs correspond to a luminal progenitor that acquires stem cell properties in the context of prostate regeneration (green arrows), thus corresponding to a facultative stem cell. $(B)$ An alternative model is that LSCs and CARNs correspond to independent stem cells that maintain basal and luminal populations, respectively. Adapted from $\mathrm{X}$ Wang et al. (2009); (c) 2009 Nature. 
suggested for CD133 (Shmelkov et al. 2008). It is also notable that existing cell culture assays are performed under conditions that select strongly against the growth of luminal cells (Peehl 2005), resulting in a significant bias toward outgrowth of basal cells and basal cell differentiation in assays such as prostasphere formation. Thus, in the absence of comprehensive in vivo approaches to investigate stem cell properties, the present data suggest that there may be multiple independent stem cell populations within the adult prostate epithelium.

\section{Cell of origin}

The tissue localization of prostate epithelial stem cells is highly relevant for investigating the putative cell type(s) of origin for prostate cancer (Lawson and Witte 2007; Kasper 2008; Maitland and Collins 2008). A cell of origin can be defined as a normal tissue cell that can be oncogenically transformed to give rise to a cancer; thus, the cell of origin refers to a cell or cell type that is found in normal untransformed tissue. In principle, cancer could result from transformation of a rare stem cell, and/or could result from transformation of a more restricted cell type (such as a transit/amplifying cell) and its "dedifferentiation" to acquire self-renewal properties characteristic of stem cells (Fig. 4). Indeed, differences in the cell of origin in the stem cell lineage hierarchy have been proposed to represent the basis for distinct tumor subtypes for breast cancer (Visvader 2009).

Given the luminal phenotype of human prostate cancer, the cell of origin should correspond to either a luminal cell, or a basal progenitor that can rapidly differentiate into luminal progeny following oncogenic transformation. A basal cell of origin has been suggested by analyses of $\mathrm{Pb}$-Cre4; Pten ${ }^{\text {flox/flox }}$ mice, which display an expansion of basal cells as well as intermediate cells coexpressing basal and luminal markers in tumors (S Wang et al. 2006). More recently, a comparison of basal and luminal epithelial populations isolated by flow cytometry from the mouse prostate has shown that basal populations are readily transformed by lentiviral expression of ERG and $\mathrm{AR}$ in tissue reconstitution experiments, whereas luminal cells are not transformed (Lawson et al. 2010). Importantly, analogous reconstitution assays using normal epithelial cells isolated from the human prostate have shown that transformed basal cells can generate prostate adenocarcinomas with luminal phenotypes (Goldstein et al. 2010).

In contrast, studies of PSA-Cre; Pten ${ }^{\text {flox } / \text { flox }}$ mice have suggested a rare luminal $\mathrm{Clu}^{+} \mathrm{Tacstd}_{2}{ }^{+} \mathrm{Sca}-1^{+}$population as corresponding to the cell of origin in this model (Korsten et al. 2009). Consistent with these findings, detailed phenotypic analysis of Probasin-Myc and $N k x 3.1-M y c$ transgenic mouse lines also suggests that PIN and prostate cancer originates from luminal cells (Iwata et al. 2010). Notably, CARNs correspond to luminal cells of origin for prostate cancer in mouse models, as evidenced by targeted deletion of Pten resulting in highgrade PIN and invasive carcinoma following androgen repletion and prostate regeneration (X Wang et al. 2009). Additional evidence is suggested by detailed histopathological analysis of MYC expression in high-grade PIN samples, which still retain basal cells, which shows that MYC up-regulation is associated exclusively with luminal cells, and is not detected in their basal neighbors (Gurel et al. 2008); similar findings have also been reported with respect to telomere shortening (Meeker et al. 2002). Also in favor of a luminal cell of origin is the recent finding that AR mediates formation of the TMPRSS2-ERG fusion in human prostate cancer cells (Lin et al. 2009; Mani et al. 2009; Haffner et al. 2010), suggesting that initiating events take place in ARexpressing luminal cells. Thus, based on the available evidence, prostate cancer can indeed arise from distinct cell types of origin, but it remains unclear whether different cells of origin are used in human prostate cancer initiation, or whether they might result in differing molecular subtypes.

\section{Identification of TICs}

The cancer stem cell model proposes that cell populations within a tumor have a hierarchical organization, in which a stem cell-like population gives rise to more differentiated derivatives that lack tumor-initiating and/or long-term self-renewal capability (Reya et al. 2001; Pardal et al. 2003; Wicha et al. 2006; Visvader and Lindeman 2008; Marotta and Polyak 2009; Rosen and Jordan 2009). This model has strong translational and clinical relevance, since it would likely have several implications for prostate cancer treatment. First, the identification of appropriate markers would allow the correlation of prostate cancer stem cell status in tumors with histopathology and clinical outcomes, and might also serve as accurate surrogates for the efficacy of cancer treatments. Second, targeted therapeutics for cancer stem cells might be superior to conventional therapies, which usually target cellular proliferation in the bulk tumor, while cancer stem cells may be relatively resistant due to a lower proliferative rate. Finally, the assessment of cancer stem cell numbers and molecular properties among circulating tumor cells might have prognostic value for the risk of metastatic disease, since the ability of circulating tumor cells to generate secondary metastases presumably requires selfrenewing cancer stem cells.

The cancer stem cell model is consistent with the observed phenotypic heterogeneity found in many tumors, including prostate adenocarcinoma. In contrast, a stochastic or clonal evolution model of tumor development suggests that the phenotypic heterogeneity of tumors is due to variations in the genetic or epigenetic composition of tumor subpopulations, but that these subpopulations are not hierarchically organized and have similar tumor-initiating ability under appropriate circumstances (Adams and Strasser 2008; Shackleton et al. 2009). In many experimental contexts, cancer stem cells are identified in assays for TICs, using xenotransplantation to isolate cancer cells that can form a tumor after grafting, most rigorously after transplantation of a single cell. However, recent work has questioned the interpretation of such studies, since technical improvements in xenotransplantation can yield significant increases in efficiency, with up to $25 \%$ of melanoma cells displaying 
tumor-initiating properties (Quintana et al. 2008). These and other studies continue to engender doubt as to the existence of cancer stem cells in many solid tumors (Hill 2006; Shackleton et al. 2009).

Flow cytometry approaches to purifying subsets of epithelial cells based on cell surface marker expression have been combined with xenograft assays to identify putative TICs isolated from mouse prostate cancer models as well as human prostate cancer specimens (Lawson and Witte 2007; Kasper 2008). In the case of mouse prostate cancer, $\mathrm{Lin}^{-} \mathrm{Sca}-\mathrm{1}^{+} \mathrm{CD} 49 \mathrm{f}^{+}$cells from PbCre4; Pten flox/flox mice have been shown to have tumor-initiating properties in renal graft and sphere-forming assays, suggesting marker conservation between normal stem cells and cancer stem cells (Mulholland et al. 2009). In human prostate cancer, CD44 has been used as a marker to enrich for TICs from established xenografts (Patrawala et al. 2006), while further enrichment of TICs was obtained in a subsequent study by sorting for $\alpha_{2} \beta_{1}$ integrin ${ }^{\text {hi }} \mathrm{CD} 44^{+}$ cells (Patrawala et al. 2007). Finally, enrichment of $\mathrm{CD}_{133^{+}} \alpha_{2} \beta_{1}$ integrin ${ }^{\text {hi }} \mathrm{CD} 44^{+}$cells from primary prostate tumor biopsies resulted in identification of cells with increased invasiveness and clonogenicity in culture /Collins et al. 2005), while molecular analyses of $\mathrm{CD}_{133^{+}} \alpha_{2} \beta_{1}$ integrin $^{\text {hi }}$ cells revealed a potential cancer stem cell signature that is enriched for components of the JAKSTAT, Wnt, and focal adhesion pathways (Birnie et al. 2008). To date, however, the successful use of cell surface markers to isolate cell populations from primary human prostate cancers with tumor-initiating capabilities in grafting assays has not yet been reported.

Despite these promising findings, it remains unclear whether normal stem cells and cancer stem cells should display conserved marker expression, or whether the markers used display specificity for putative cancer stem cells. Second, the candidate TICs isolated to date display prevalent basal cell differentiation in vivo and in vitro, which is unexpected, since the primary tumors from which these cells were derived presumably lack basal cells. Finally, the putative TICs lack expression of AR, which is surprising given the strong selection for $A R$ activity throughout prostate cancer progression, and the known mechanisms for castration resistance (Sharifi et al. 2006). These concerns suggest that authentic prostate cancer stem cells have not yet been definitively identified.

\section{Translational applications}

In recent years, principal areas of translational research on prostate cancer have focused on (1) understanding the dietary/lifestyle/environmental factors that influence prostate carcinogenesis, and identifying strategies to delay its onset or progression; (2) identifying biomarkers that distinguish indolent versus aggressive forms of the disease, and the application of such biomarkers for patient stratification; and (3) developing new therapeutic approaches for the treatment of castration-resistant prostate cancer, as well as for prevention of bone metastases. For instance, one example of a novel therapeutic approach that may be promising is the use of immunotherapy, as exemplified by the recent FDA approval of a therapeutic vaccine (Provenge) for advanced prostate cancer patients (Harzstark and Small 2007; Morse and Whelan 2010). Below, we briefly highlight major directions for translational research, focusing on how they can benefit from basic research, recent technological advances, and/or the application of robust preclinical models for in vivo analyses.

\section{Dietary and lifestyle factors in cancer prevention}

Epidemiologic investigations support the idea that dietary/lifestyle factors are major contributors of population differences in the occurrence of clinical prostate cancer (Kolonel et al. 2000, Kolonel 2001). In particular, dietary/lifestyle differences may account for the considerable difference in incidence of clinical prostate cancer between Asian and American populations, reflecting a shift in the rate of cancer detection by $\sim 10$ years; notably, this discrepancy in cancer rate disappears when Asians immigrate to Western countries (Hanenszel and Kurihari 1968; Dunn 1975). However, the molecular/ mechanistic bases for these differences have not been fully explained.

Considerable data support the hypothesis that dietary/ lifestyle factors affect prostate cancer incidence by promoting chronic inflammation and/or oxidative stress, ultimately leading to DNA damage, epigenetic modifications, or other perturbations associated with cancer initiation (De Marzo et al. 2007a; Nelson 2007). This model has consequently emphasized the role of antioxidants and anti-inflamatory agents in protection against prostate cancer (DeWeese et al. 2001). Some prevention trials testing this model have been successful, including one showing that consumption of large quantities of tomato, which contain the potent antioxidant lycopene, results in reduced prostate cancer incidence (Chen et al. 2001). However, other trials have not shown that supplementation with antioxidants will reduce prostate cancer risk (Kirsh et al. 2006). A particular disappointment was the outcome of the SELECT trial, which found no benefit to supplementation with selenium and vitamin E (Lippman et al. 2009).

Additional studies have addressed the potential efficacy of antioxidants, anti-inflammatory agents, and/or other dietary factors by using epidemiological findings to investigate preclinical mouse models. For example, based on an extensive body of literature indicating that dietary restriction is anti-tumorigenic, analyses of dietary restriction or low-fat diets on cancer progression in genetically engineered mice has revealed the PI3K-Akt signaling pathway as a molecular target for these dietary interventions (Berquin et al. 2007; Kobayashi et al. 2008; Kalaany and Sabatini 2009). Another promising agent is vitamin $\mathrm{D}$, which has been suggested by ample epidemiological evidence to protect against tumorigenesis, but has displayed variable efficacy in clinical trials (Deeb et al. 2007). Notably, analyses in genetically engineered mice that have shown that the timing of vitamin $\mathrm{D}$ administration is critical, as its beneficial effects are only realized early in cancer progression, as it promotes 
expression of the vitamin D receptor in prostate epithelial cells (Banach-Petrosky et al. 2006). These examples highlight the importance of integrating epidemiological analyses with systematic evaluation of mechanisms in preclinical models for effective design and implementation of dietary interventions for cancer prevention.

\section{Biomarker discovery}

PSA testing has revolutionized the diagnosis of prostate cancer, since it is now possible to detect most prostate tumors at early stages, unlike other cancers that lack a straightforward method for early detection. However, the early detection of prostate cancer needs to be augmented by improved biomarkers that can stratify patients in conjunction with Gleason grading. The search for effective biomarkers has included gene expression profiling, miRNA expression profiling, serum proteomics, and metabolomics. The latter represents a promising new approach that may allow for the development of noninvasive urine tests for cancer metabolites to detect prostate and other cancers (Sreekumar et al. 2009). More generally, the investigation of potential urine biomarkers has led to the identification of PCA3 (prostate cancer antigen 31, a promising marker for predicting disease outcome (Ploussard and de la Taille 2010).

However, to date, few if any biomarkers are now being used that can predict disease outcome more effectively than Gleason score alone. In principle, suitable combinations of markers may be successful in cumulatively predicting outcome, as enabled by new technologies such as molecular systems pathology (Cordon-Cardo et al. 2007). Alternatively, system biology approaches that identify master regulatory genes of disease progression may enable the effective stratification of patients, as has been applied for other cancer types (Carro et al. 2009). Finally, comprehensive oncogenomic approaches that integrate gene expression and copy number analyses may identify new biomarkers for predicting disease outcome (Taylor et al. 2010).

\section{Manipulating AR signaling for prevention and treatment}

The essential role of AR signaling for the development of prostate cancer provided the rationale for a large-scale prevention trial that evaluated the $5 \alpha$-reductase inhibitor finasteride for prevention of prostate cancer (Higgins and Thompson 2004). The results of this trial were encouraging, since they showed a $24 \%$ reduction in prostate cancer incidence, which has led to the recommendation of finasteride administration for men in high-risk categories. As a cautionary note, however, a subset of patients in this trial appeared to develop more aggressive disease (Lucia et al. 2007), which may reflect a selection for men predisposed to limiting levels of androgens, as has been suggested by studies of limiting androgen levels for cancer progression in genetically engineered mice (Banach-Petrosky et al. 2007).

AR has also been a primary target for treatment of patients with advanced disease. Based on the central role of $\mathrm{AR}$ in castration resistance, novel AR pathway inhibitors could potentially provide important therapeutics for advanced prostate cancer (Attar et al. 2009; Y Chen et al. 2009; Knudsen and Scher 2009). In this regard, a second-generation AR antagonist, MDV3100, which completely lacks agonist activity and binds AR with greater affinity than bicalutamide, has provided new insights into castration resistance, and has given promising results in mouse models and in a human phase 1-2 trial (Tran et al. 2009; Scher et al. 2010). Other agents that target the $\mathrm{N}$-terminal transcriptional regulatory region of AR are now being evaluated in cell lines and mouse models (Andersen et al. 2010). Another promising AR pathway antagonist is abiraterone acetate, which inhibits the activity of CYP17, an enzyme required for two steps in androgen biosynthesis, and has shown promising results in initial clinical trials (Attard et al. 2009b; Y Chen et al. 2009).

\section{Targeting signaling pathways in treatment of advanced disease}

For reasons that are poorly understood, the therapeutic benefits of standard chemotherapy regimens are limited in patients with advanced prostate cancer, although improvements have been made in the past several years (Calabro and Sternberg 2007; Petrylak 2007). Therefore, recent approaches have been aimed at targeting signaling pathways activated in advanced prostate cancer, including the Akt/mTOR and MAPK signaling pathways. The evaluation of Rapamycin and related compounds (Rapalogs) that target mTOR signaling in preclinical trials in genetically engineered mutant mice and in human clinical trials suggest that these may not be effective as single agents (Sawyers 2003; Garcia-Echeverria and Sellers 2008; Morgan et al. 2009). However, combination therapy using $\mathrm{Akt} / \mathrm{mTOR}$ inhibitors in conjunction with first-line chemotherapy or agents that target other key signaling pathways such as the Erk MAPK pathway may be highly effective, as has been suggested by preclinical studies in which combination therapy effectively blocks castrationresistant prostate cancer in mice (Kinkade et al. 2008). Thus, the development of combination therapy for treatment of advanced prostate cancer will likely benefit from evaluation in robust preclinical models.

\section{Perspectives and conclusions}

Considering the tremendous progress made in the past 10 years, we envision continuing advances over the next decade in areas of research that will facilitate effective strategies for the prevention, diagnosis, and treatment of prostate cancer. Among the challenges for future studies will be to integrate epidemiological studies with molecular investigations and clinical analyses to gain fundamental insights into how environmental, dietary, and lifestyle influences contribute to the development of prostate cancer, and to identify the molecular factors that are altered by these influences and how they can be modified by appropriate dietary or chemical interventions. Of paramount importance will be the effective 
diagnosis of men that have prostate cancer, and their stratification into high-risk and low-risk groups for treatment management. Thus, biomarker discovery will likely represent a considerable emphasis for future research, perhaps focused on identification of master regulator genes that can provide accurate readouts of signaling pathways associated with disease progression. Moreover, considering that prostate cancer is fairly indolent, the development of treatment approaches that delay its onset or progression is likely to have a significant impact on outcome. Finally, more effective strategies will be necessary for preventing the transition to lethal forms of prostate cancer, which will require a deeper understanding of the mechanisms underlying castration-resistant prostate cancer and the bone tropism of prostate cancer metastasis. Thus, while our knowledge of the molecular genetics of prostate cancer has greatly expanded in the past decade, much work remains to be done to enhance the overall rate of prostate cancer survival.

\section{Acknowledgments}

We apologize to our colleagues for our inability to discuss and cite numerous important studies, due to length constraints. We thank Robert Cardiff and Alexander Borowsky for assistance with Figure 2, and Arul Chinnaiyan, Angelo De Marzo, Edward Gelmann, and Charles Sawyers for helpful discussions. This work was supported by grants to M.M.S. and C.A.-S. from the NIH, DOD Prostate Cancer Research Program, and NCI Mouse Models of Human Cancer Consortium.

\section{References}

Abate-Shen C, Shen MM. 2000. Molecular genetics of prostate cancer. Genes Dev 14: 2410-2434.

Abate-Shen C, Banach-Petrosky WA, Sun X, Economides KD, Desai N, Gregg JP, Borowsky AD, Cardiff RD, Shen MM. 2003. Nkx3.1; Pten mutant mice develop invasive prostate adenocarcinoma and lymph node metastases. Cancer Res 63: 3886-3890.

Abate-Shen C, Shen MM, Gelmann E. 2008. Integrating differentiation and cancer: The Nkx3.1 homeobox gene in prostate organogenesis and carcinogenesis. Differentiation 76: 717-727.

Abdulkadir SA, Magee JA, Peters TJ, Kaleem Z, Naughton CK, Humphrey PA, Milbrandt J. 2002. Conditional loss of Nkx3.1 in adult mice induces prostatic intraepithelial neoplasia. Mol Cell Biol 22: 1495-1503.

Abreu-Martin MT, Chari A, Palladino AA, Craft NA, Sawyers CL. 1999. Mitogen-activated protein kinase kinase kinase 1 activates androgen receptor-dependent transcription and apoptosis in prostate cancer. Mol Cell Biol 19: 5143-5154.

Acevedo VD, Gangula RD, Freeman KW, Li R, Zhang Y, Wang F, Ayala GE, Peterson LE, Ittmann M, Spencer DM. 2007. Inducible FGFR-1 activation leads to irreversible prostate adenocarcinoma and an epithelial-to-mesenchymal transition. Cancer Cell 12: 559-571.

Adams JM, Strasser A. 2008. Is tumor growth sustained by rare cancer stem cells or dominant clones? Cancer Res 68: 40184021.

Adam RM, Mukhopadhyay NK, Kim J, Di Vizio D, Cinar B, Boucher K, Solomon KR, Freeman MR. 2007. Cholesterol sensitivity of endogenous and myristoylated Akt. Cancer Res 67: 6238-6246.
Agoulnik IU, Vaid A, Bingman WE III, Erdeme H, Frolov A, Smith CL, Ayala G, Ittmann MM, Weigel NL. 2005. Role of SRC-1 in the promotion of prostate cancer cell growth and tumor progression. Cancer Res 65: 7959-7967.

Aihara M, Wheeler TM, Ohori M, Scardino PT. 1994. Heterogeneity of prostate cancer in radical prostatectomy specimens. Urology 43: 60-66.

Albadine R, Latour M, Toubaji A, Haffner M, Isaacs WB, Platz EA, Meeker AK, Demarzo AM, Epstein JI, Netto GJ 2009. TMPRSS2-ERG gene fusion status in minute (minimal) prostatic adenocarcinoma. Mod Pathol 22: 1415-1422.

Albertsen PC, Hanley JA, Fine J. 2005. 20-year outcomes following conservative management of clinically localized prostate cancer. JAMA 293: 2095-2101.

Alimonti A, Nardella C, Chen Z, Clohessy JG, Carracedo A, Trotman LC, Cheng K, Varmeh S, Kozma SC, Thomas G, et al. 2010. A novel type of cellular senescence that can be enhanced in mouse models and human tumor xenografts to suppress prostate tumorigenesis. I Clin Invest 120: 681-693.

Al Olama AA, Kote-Jarai Z, Giles GG, Guy M, Morrison J, Severi G, Leongamornlert DA, Tymrakiewicz M, Jhavar S, Saunders E, et al. 2009. Multiple loci on 8q24 associated with prostate cancer susceptibility. Nat Genet 41: 1058-1060.

Ambs S, Prueitt RL, Yi M, Hudson RS, Howe TM, Petrocca F, Wallace TA, Liu CG, Volinia S, Calin GA, et al. 2008. Genomic profiling of microRNA and messenger RNA reveals deregulated microRNA expression in prostate cancer. Cancer Res 68: 6162-6170.

American_Cancer_Society. 2009. Cancer facts \& figures 2009. American Cancer Society, Atlanta, GA.

Amundadottir LT, Sulem P, Gudmundsson J, Helgason A, Baker A, Agnarsson BA, Sigurdsson A, Benediktsdottir KR, Cazier JB, Sainz J, et al. 2006. A common variant associated with prostate cancer in European and African populations. Nat Genet 38: 652-658.

Andersen RJ, Mawji NR, Wang J, Wang G, Haile S, Myung JK, Watt K, Tam T, Yang YC, Banuelos CA, et al. 2010. Regression of castrate-recurrent prostate cancer by a smallmolecule inhibitor of the amino-terminus domain of the androgen receptor. Cancer Cell 17: 535-546.

Asai A, Oshima Y, Yamamoto Y, Uochi TA, Kusaka H, Akinaga S, Yamashita Y, Pongracz K, Pruzan R, Wunder E, et al. 2003. A novel telomerase template antagonist (GRN163) as a potential anticancer agent. Cancer Res 63: 3931-3939.

Asatiani E, Huang WX, Wang A, Rodriguez Ortner E, Cavalli LR, Haddad BR, Gelmann EP. 2005. Deletion, methylation, and expression of the NKX3.1 suppressor gene in primary human prostate cancer. Cancer Res 65: 1164-1173.

Attar RM, Takimoto CH, Gottardis MM. 2009. Castrationresistant prostate cancer: Locking up the molecular escape routes. Clin Cancer Res 15: 3251-3255.

Attard G, Cooper CS, de Bono JS. 2009a. Steroid hormone receptors in prostate cancer: A hard habit to break? Cancer Cell 16: 458-462.

Attard G, Reid AH, Olmos D, de Bono JS. 2009b. Antitumor activity with CYP17 blockade indicates that castrationresistant prostate cancer frequently remains hormone driven. Cancer Res 69: 4937-4940.

Attard G, Swennenhuis JF, Olmos D, Reid AH, Vickers E, A'Hern R, Levink R, Coumans F, Moreira J, Riisnaes R, et al. 2009c. Characterization of ERG, AR and PTEN gene status in circulating tumor cells from patients with castration-resistant prostate cancer. Cancer Res 69: 2912-2918.

Bachmann IM, Halvorsen OJ, Collett K, Stefansson IM, Straume O, Haukaas SA, Salvesen HB, Otte AP, Akslen LA. 2006. 
EZH2 expression is associated with high proliferation rate and aggressive tumor subgroups in cutaneous melanoma and cancers of the endometrium, prostate, and breast. I Clin Oncol 24: 268-273.

Bai F, Pei XH, Pandolfi PP, Xiong Y. 2006. p18 Ink4c and Pten constrain a positive regulatory loop between cell growth and cell cycle control. Mol Cell Biol 26: 4564-4576.

Banach-Petrosky W, Ouyang X, Gao H, Nader K, Ji Y, Suh N, DiPaola RS, Abate-Shen C. 2006. Vitamin D inhibits the formation of prostatic intraepithelial neoplasia in Nkx3.1;Pten mutant mice. Clin Cancer Res 12: 5895-5901.

Banach-Petrosky W, Jessen WJ, Ouyang X, Gao H, Rao J, Quinn J, Aronow BJ, Abate-Shen C. 2007. Prolonged exposure to reduced levels of androgen accelerates prostate cancer progression in Nkx3.1; Pten mutant mice. Cancer Res 67: 90899096.

Bardia A, Platz EA, Yegnasubramanian S, De Marzo AM, Nelson WG. 2009. Anti-inflammatory drugs, antioxidants, and prostate cancer prevention. Curr Opin Pharmacol 9: 419-426.

Bavik C, Coleman I, Dean JP, Knudsen B, Plymate S, Nelson PS. 2006. The gene expression program of prostate fibroblast senescence modulates neoplastic epithelial cell proliferation through paracrine mechanisms. Cancer Res 66: 794-802.

Begley L, Monteleon C, Shah RB, Macdonald JW, Macoska JA. 2005. CXCL12 overexpression and secretion by aging fibroblasts enhance human prostate epithelial proliferation in vitro. Aging Cell 4: 291-298.

Bergerat JP, Ceraline J. 2009. Pleiotropic functional properties of androgen receptor mutants in prostate cancer. Hum Mutat 30: $145-157$.

Berman DM, Desai N, Wang X, Karhadkar SS, Reynon M, AbateShen C, Beachy PA, Shen MM. 2004. Roles for Hedgehog signaling in androgen production and prostate ductal morphogenesis. Dev Biol 267: 387-398.

Berquin IM, Min Y, Wu R, Wu H, Chen YQ. 2005. Expression signature of the mouse prostate. I Biol Chem 280: 3644236451.

Berquin IM, Min Y, Wu R, Wu J, Perry D, Cline JM, Thomas MJ, Thornburg T, Kulik G, Smith A, et al. 2007. Modulation of prostate cancer genetic risk by omega-3 and omega- 6 fatty acids. J Clin Invest 117: 1866-1875.

Berruti A, Mosca A, Porpiglia F, Bollito E, Tucci M, Vana F, Cracco C, Torta M, Russo L, Cappia S, et al. 2007. Chromogranin A expression in patients with hormone naive prostate cancer predicts the development of hormone refractory disease. J Urol 178: 838-843, quiz 1129.

Bertram J, Peacock JW, Fazli L, Mui AL, Chung SW, Cox ME, Monia B, Gleave ME, Ong CJ. 2006. Loss of PTEN is associated with progression to androgen independence. Prostate 66: 895-902.

Bethel CR, Faith D, Li X, Guan B, Hicks JL, Lan F, Jenkins RB, Bieberich CJ, De Marzo AM. 2006. Decreased NKX3.1 protein expression in focal prostatic atrophy, prostatic intraepithelial neoplasia, and adenocarcinoma: Association with gleason score and chromosome $8 \mathrm{p}$ deletion. Cancer Res 66: 10683-10690.

Bethel CR, Chaudhary J, Anway MD, Brown TR. 2009. Gene expression changes are age-dependent and lobe-specific in the brown Norway rat model of prostatic hyperplasia. Prostate 69: 838-850.

Bhatia-Gaur R, Donjacour AA, Sciavolino PJ, Kim M, Desai N, Young P, Norton CR, Gridley T, Cardiff RD, Cunha GR, et al. 1999. Roles for $N k \times 3.1$ in prostate development and cancer. Genes Dev 13: 966-977.

Bhowmick NA, Chytil A, Plieth D, Gorska AE, Dumont N, Shappell S, Washington MK, Neilson EG, Moses HL. 2004.
TGF- $\beta$ signaling in fibroblasts modulates the oncogenic potential of adjacent epithelia. Science 303: 848-851.

Birbach A, Casanova E, Schmid JA. 2009. A Probasin-MerCreMer $\mathrm{BAC}$ allows inducible recombination in the mouse prostate. Genesis 47: 757-764.

Birnie R, Bryce SD, Roome C, Dussupt V, Droop A, Lang SH, Berry PA, Hyde CF, Lewis JL, Stower MJ, et al. 2008. Gene expression profiling of human prostate cancer stem cells reveals a pro-inflammatory phenotype and the importance of extracellular matrix interactions. Genome Biol 9: R83. doi: 10.1186/gb-2008-9-5-r83.

Blum DL, Koyama T, M'Koma AE, Iturregui JM, Martinez-Ferrer M, Uwamariya C, Smith JA Jr, Clark PE, Bhowmick NA. 2008. Chemokine markers predict biochemical recurrence of prostate cancer following prostatectomy. Clin Cancer Res 14: 7790-7797.

Bonci D, Coppola V, Musumeci M, Addario A, Giuffrida R, Memeo L, D'Urso L, Pagliuca A, Biffoni M, Labbaye C, et al. 2008. The miR-15a-miR-16-1 cluster controls prostate cancer by targeting multiple oncogenic activities. Nat Med 14: 1271-1277.

Bonkhoff H, Berges R. 2010. From pathogenesis to prevention of castration resistant prostate cancer. Prostate 70: 100-112.

Boormans JL, Hermans KG, van Leenders GJ, Trapman J, Verhagen PC. 2008. An activating mutation in AKT1 in human prostate cancer. Int I Cancer 123: 2725-2726.

Borowsky AD, Dingley KH, Ubick E, Turteltaub KW, Cardiff RD, Devere-White R. 2006. Inflammation and atrophy precede prostatic neoplasia in a PhIP-induced rat model. Neoplasia 8: 708-715.

Bostwick DG. 1989. Prostatic intraepithelial neoplasia (PIN). Urology 34: 16-22.

Bostwick DG, Shan A, Qian J, Darson M, Maihle NJ, Jenkins RB, Cheng L. 1998. Independent origin of multiple foci of prostatic intraepithelial neoplasia: Comparison with matched foci of prostate carcinoma. Cancer 83: 1995-2002.

Bostwick DG, Alexander EE, Singh R, Shan A, Qian J, Santella RM, Oberley LW, Yan T, Zhong W, Jiang X, et al. 2000. Antioxidant enzyme expression and reactive oxygen species damage in prostatic intraepithelial neoplasia and cancer. Cancer 89: 123-134.

Bowen C, Gelmann EP. 2010. NKX3.1 activates cellular response to DNA damage. Cancer Res 70: 3089-3097.

Bowen C, Bubendorf L, Voeller HJ, Slack R, Willi N, Sauter G, Gasser TC, Koivisto P, Lack EE, Kononen J, et al. 2000. Loss of NKX3.1 expression in human prostate cancers correlates with tumor progression. Cancer Res 60: 6111-6115.

Brooke GN, Parker MG, Bevan CL. 2008. Mechanisms of androgen receptor activation in advanced prostate cancer: Differential co-activator recruitment and gene expression. Oncogene 27: 2941-2950.

Bruxvoort KJ, Charbonneau HM, Giambernardi TA, Goolsby JC, Qian CN, Zylstra CR, Robinson DR, Roy-Burman P, Shaw AK, Buckner-Berghuis BD, et al. 2007. Inactivation of Apc in the mouse prostate causes prostate carcinoma. Cancer Res 67: 2490-2496.

Bryant RJ, Winder SJ, Cross SS, Hamdy FC, Cunliffe VT. 2008. The Polycomb Group protein EZH2 regulates actin polymerization in human prostate cancer cells. Prostate 68: 255-263.

Bubendorf L, Schopfer A, Wagner U, Sauter G, Moch H, Willi N, Gasser TC, Mihatsch MJ. 2000. Metastatic patterns of prostate cancer: An autopsy study of 1,589 patients. Hum Pathol 31: 578-583.

Burger PE, Xiong X, Coetzee S, Salm SN, Moscatelli D, Goto K, Wilson EL. 2005. Sca-1 expression identifies stem cells in the proximal region of prostatic ducts with high capacity to reconstitute prostatic tissue. Proc Natl Acad Sci 102: 7180-7185. 
Calabro F, Sternberg CN. 2007. Current indications for chemotherapy in prostate cancer patients. Eur Urol 51: 17-26.

Cao Q, Yu J, Dhanasekaran SM, Kim JH, Mani RS, Tomlins SA, Mehra R, Laxman B, Cao X, Kleer CG, et al. 2008. Repression of E-cadherin by the polycomb group protein EZH2 in cancer. Oncogene 27: 7274-7284.

Capasso LL. 2005. Antiquity of cancer. Int J Cancer 113: 2-13.

Carpten J, Nupponen N, Isaacs S, Sood R, Robbins C, Xu J, Faruque M, Moses T, Ewing C, Gillanders E, et al. 2002. Germline mutations in the ribonuclease $\mathrm{L}$ gene in families showing linkage with HPC1. Nat Genet 30: 181-184.

Carro MS, Lim WK, Alvarez MJ, Bollo RJ, Zhao X, Snyder EY, Sulman EP, Anne SL, Doetsch F, Colman H, et al. 2009. The transcriptional network for mesenchymal transformation of brain tumours. Nature 463: 318-325.

Carver BS, Tran J, Gopalan A, Chen Z, Shaikh S, Carracedo A, Alimonti A, Nardella C, Varmeh S, Scardino PT, et al. 2009. Aberrant ERG expression cooperates with loss of PTEN to promote cancer progression in the prostate. Nat Genet 41: 619-624.

Casey G, Neville PJ, Plummer SJ, Xiang Y, Krumroy LM, Klein EA, Catalona WJ, Nupponen N, Carpten JD, Trent JM, et al. 2002. RNASEL Arg462Gln variant is implicated in up to $13 \%$ of prostate cancer cases. Nat Genet 32: 581-583.

Castro P, Giri D, Lamb D, Ittmann M. 2003. Cellular senescence in the pathogenesis of benign prostatic hyperplasia. Prostate 55: 30-38.

Chen L, Stacewicz-Sapuntzakis M, Duncan C, Sharifi R, Ghosh $\mathrm{L}$, van Breemen $\mathrm{R}$, Ashton D, Bowen PE. 2001. Oxidative DNA damage in prostate cancer patients consuming tomato sauce-based entrees as a whole-food intervention. I Natl Cancer Inst 93: 1872-1879.

Chen Z, Koeneman KS, Corey DR. 2003. Consequences of telomerase inhibition and combination treatments for the proliferation of cancer cells. Cancer Res 63: 5917-5925.

Chen CD, Welsbie DS, Tran C, Baek SH, Chen R, Vessella R, Rosenfeld MG, Sawyers CL. 2004. Molecular determinants of resistance to antiandrogen therapy. Nat Med 10: 33-39.

Chen H, Tu SW, Hsieh JT. 2005. Down-regulation of human DAB2IP gene expression mediated by polycomb Ezh2 complex and histone deacetylase in prostate cancer. J Biol Chem 280: $22437-22444$.

Chen Z, Trotman LC, Shaffer D, Lin HK, Dotan ZA, Niki M, Koutcher JA, Scher HI, Ludwig T, Gerald W, et al. 2005. Crucial role of p53-dependent cellular senescence in suppression of Pten-deficient tumorigenesis. Nature 436: 725-730.

Chen L, Ambrosone CB, Lee J, Sellers TA, Pow-Sang J, Park JY. 2006. Association between polymorphisms in the DNA repair genes XRCC1 and APE1, and the risk of prostate cancer in white and black Americans. J Urol 175: 108-112.

Chen ML, Xu PZ, Peng XD, Chen WS, Guzman G, Yang X, Di Cristofano A, Pandolfi PP, Hay N. 2006. The deficiency of Akt1 is sufficient to suppress tumor development in $\mathrm{Pten}^{+/-}$ mice. Genes Dev 20: 1569-1574.

Chen Y, Clegg NJ, Scher HI. 2009. Anti-androgens and androgendepleting therapies in prostate cancer: New agents for an established target. Lancet Oncol 10: 981-991.

Chen Z, Carracedo A, Lin HK, Koutcher JA, Behrendt N, Egia A, Alimonti A, Carver BS, Gerald W, Teruya-Feldstein J, et al. 2009. Differential p53-independent outcomes of p19(Arf) loss in oncogenesis. Sci Signal 2: ra44. doi: 10.1126/scisignal. 2000053.

Chin L, Tam A, Pomerantz J, Wong M, Holash J, Bardeesy N, Shen Q, O'Hagan R, Pantginis J, Zhou H, et al. 1999. Essential role for oncogenic Ras in tumour maintenance. Nature 400: 468-472.
Chiosea S, Jelezcova E, Chandran U, Acquafondata M, McHale T, Sobol RW, Dhir R. 2006. Up-regulation of dicer, a component of the microRNA machinery, in prostate adenocarcinoma. Am J Pathol 169: 1812-1820.

Choi J, Shendrik I, Peacocke M, Peehl D, Buttyan R, Ikeguchi EF, Katz AE, Benson MC. 2000. Expression of senescenceassociated $\beta$-galactosidase in enlarged prostates from men with benign prostatic hyperplasia. Urology 56: 160-166.

Clark J, Merson S, Jhavar S, Flohr P, Edwards S, Foster CS, Eeles R, Martin FL, Phillips DH, Crundwell M, et al. 2007. Diversity of TMPRSS2-ERG fusion transcripts in the human prostate. Oncogene 26: 2667-2673.

Clark J, Attard G, Jhavar S, Flohr P, Reid A, De-Bono J, Eeles R, Scardino P, Cuzick J, Fisher G, et al. 2008. Complex patterns of ETS gene alteration arise during cancer development in the human prostate. Oncogene 27: 1993-2003.

Collins AT, Berry PA, Hyde C, Stower MJ, Maitland NJ. 2005. Prospective identification of tumorigenic prostate cancer stem cells. Cancer Res 65: 10946-10951.

Coppola V, De Maria R, Bonci D. 2009. MicroRNAs and prostate cancer. Endocr Relat Cancer 17: F1-F17. doi: 10.1677/ERC09-0172.

Cordon-Cardo C, Kotsianti A, Verbel DA, Teverovskiy M, Capodieci P, Hamann S, Jeffers Y, Clayton M, Elkhettabi F, Khan FM, et al. 2007. Improved prediction of prostate cancer recurrence through systems pathology. I Clin Invest 117: $1876-1883$.

Corey E, Quinn JE, Bladou F, Brown LG, Roudier MP, Brown JM, Buhler KR, Vessella RL. 2002. Establishment and characterization of osseous prostate cancer models: Intra-tibial injection of human prostate cancer cells. Prostate 52: 20-33.

Courtois-Cox S, Jones SL, Cichowski K. 2008. Many roads lead to oncogene-induced senescence. Oncogene 27: 2801-2809.

Craft N, Chhor C, Tran C, Belldegrun A, DeKernion J, Witte ON, Said J, Reiter RE, Sawyers CL. 1999a. Evidence for clonal outgrowth of androgen-independent prostate cancer cells from androgen-dependent tumors through a two-step process. Cancer Res 59: 5030-5036.

Craft N, Shostak Y, Carey M, Sawyers CL. 1999b. A mechanism for hormone-independent prostate cancer through modulation of androgen receptor signaling by the HER-2/neu tyrosine kinase. Nat Med 5: 280-285.

Cunha GR. 2008. Mesenchymal-epithelial interactions: Past, present, and future. Differentiation 76: 578-586.

Cunha GR, Donjacour AA, Cooke PS, Mee S, Bigsby RM, Higgins SJ, Sugimura Y. 1987. The endocrinology and developmental biology of the prostate. Endocr Rev 8: 338-362.

d'Adda di Fagagna F. 2008. Living on a break: Cellular senescence as a DNA-damage response. Nat Rev Cancer 8: 512-522.

Dakhova O, Ozen M, Creighton CJ, Li R, Ayala G, Rowley D, Ittmann M. 2009. Global gene expression analysis of reactive stroma in prostate cancer. Clin Cancer Res 15: 3979-3989.

Dan HC, Cooper MJ, Cogswell PC, Duncan JA, Ting JP, Baldwin AS. 2008. Akt-dependent regulation of NF-кB is controlled by $\mathrm{mTOR}$ and Raptor in association with IKK. Genes \& DeV 22: $1490-1500$.

Deeb KK, Trump DL, Johnson CS. 2007. Vitamin D signalling pathways in cancer: Potential for anticancer therapeutics. Nat Rev Cancer 7: 684-700.

Dehm SM, Schmidt LJ, Heemers HV, Vessella RL, Tindall DJ. 2008. Splicing of a novel androgen receptor exon generates a constitutively active androgen receptor that mediates prostate cancer therapy resistance. Cancer Res 68: 5469-5477.

De Marzo AM, Marchi VL, Epstein JI, Nelson WG. 1999. Proliferative inflammatory atrophy of the prostate: Implications for prostatic carcinogenesis. Am I Pathol 155: 1985-1992. 
De Marzo AM, Meeker AK, Zha S, Luo J, Nakayama M, Platz EA, Isaacs WB, Nelson WG. 2003. Human prostate cancer precursors and pathobiology. Urology 62: 55-62.

De Marzo AM, Nakai Y, Nelson WG. 2007a. Inflammation, atrophy, and prostate carcinogenesis. Urol Oncol 25: 398400.

De Marzo AM, Platz EA, Sutcliffe S, Xu J, Gronberg H, Drake CG, Nakai Y, Isaacs WB, Nelson WG. 2007b. Inflammation in prostate carcinogenesis. Nat Rev Cancer 7: 256-269.

DeMarzo AM, Nelson WG, Isaacs WB, Epstein JI. 2003. Pathological and molecular aspects of prostate cancer. Lancet 361: 955-964.

DeVere White RW, Vinall RL, Tepper CG, Shi XB. 2009. MicroRNAs and their potential for translation in prostate cancer. Urol Oncol 27: 307-311.

DeWeese TL, Hruszkewycz AM, Marnett LJ. 2001. Oxidative stress in chemoprevention trials. Urology 57: 137-140.

Di Cristofano A, Pesce B, Cordon-Cardo C, Pandolfi PP. 1998a. Pten is essential for embryonic development and tumour suppression. Nat Genet 19: 348-355.

Di Cristofano A, Pesce B, Cordon-Cardo C, Pandolfi PP. 1998b. Pten is essential for embryonic development and tumour suppression. Nat Genet 19: 348-355.

Di Cristofano A, De Acetis M, Koff A, Cordon-Cardo C, Pandolfi PP. 2001. Pten and p27KIP1 cooperate in prostate cancer tumor suppression in the mouse. Nat Genet 27: 222-224.

Doles J, Cook C, Shi X, Valosky J, Lipinski R, Bushman W. 2006. Functional compensation in Hedgehog signaling during mouse prostate development. Dev Biol 295: 13-25.

Dong JT. 2001. Chromosomal deletions and tumor suppressor genes in prostate cancer. Cancer Metastasis Rev 20: 173-193.

Dong B, Kim S, Hong S, Das Gupta I, Malathi K, Klein EA, Ganem D, Derisi JL, Chow SA, Silverman RH. 2007. An infectious retrovirus susceptible to an IFN antiviral pathway from human prostate tumors. Proc Natl Acad Sci 104: 16551660.

Donjacour AA, Thomson AA, Cunha GR. 2003. FGF-10 plays an essential role in the growth of the fetal prostate. Dev Biol 261: 39-54.

Dunn JE. 1975. Cancer epidemiology in populations of the United States-with emphasis on Hawaii and California-and Japan. Cancer Res 35: 3240-3245.

Eeles RA, Kote-Jarai Z, Al Olama AA, Giles GG, Guy M, Severi G, Muir K, Hopper JL, Henderson BE, Haiman CA, et al. 2009. Identification of seven new prostate cancer susceptibility loci through a genome-wide association study. Nat Genet 41: 1116-1121.

Eggener SE, Scardino PT, Carroll PR, Zelefsky MJ, Sartor O, Hricak H, Wheeler TM, Fine SW, Trachtenberg J, Rubin MA, et al. 2007. Focal therapy for localized prostate cancer: A critical appraisal of rationale and modalities. I Urol 178: 2260-2267.

Elkahwaji JE, Zhong W, Hopkins WJ, Bushman W. 2007. Chronic bacterial infection and inflammation incite reactive hyperplasia in a mouse model of chronic prostatitis. Prostate 67: 14-21.

Elkahwaji JE, Hauke RJ, Brawner CM. 2009. Chronic bacterial inflammation induces prostatic intraepithelial neoplasia in mouse prostate. Br J Cancer 101: 1740-1748.

Ellis WJ, Vessella RL, Buhler KR, Bladou F, True LD, Bigler SA, Curtis D, Lange PH. 1996. Characterization of a novel androgen-sensitive, prostate-specific antigen-producing prostatic carcinoma xenograft: LuCaP 23. Clin Cancer Res 2: $1039-1048$.

Ellwood-Yen K, Graeber TG, Wongvipat J, Iruela-Arispe ML, Zhang J, Matusik R, Thomas GV, Sawyers CL. 2003. Myc- driven murine prostate cancer shares molecular features with human prostate tumors. Cancer Cell 4: 223-238.

Emmert-Buck MR, Vocke CD, Pozzatti RO, Duray PH, Jennings SB, Florence CD, Zhuang Z, Bostwick DG, Liotta LA, Linehan WM. 1995. Allelic loss on chromosome 8p12-21 in microdissected prostatic intraepithelial neoplasia. Cancer Res 55: 2959-2962.

English HF, Santen RJ, Isaacs JT. 1987. Response of glandular versus basal rat ventral prostatic epithelial cells to androgen withdrawal and replacement. Prostate 11: 229-242.

Epstein JI. 2010. An update of the Gleason grading system. J Urol 183: 433-440.

Evan GI, d'Adda di Fagagna F. 2009. Cellular senescence: Hot or what? Curr Opin Genet Dev 19: 25-31.

Evans GS, Chandler JA. 1987. Cell proliferation studies in the rat prostate: II. The effects of castration and androgeninduced regeneration upon basal and secretory cell proliferation. Prostate 11: 339-351.

Fizazi K. 2007. The role of Src in prostate cancer. Ann Oncol 18: 1765-1773.

Fordyce CA, Heaphy CM, Joste NE, Smith AY, Hunt WC, Griffith JK. 2005. Association between cancer-free survival and telomere DNA content in prostate tumors. I Urol 173: 610-614.

Foster BA, Evangelou A, Gingrich JR, Kaplan PJ, DeMayo F, Greenberg NM. 2002. Enforced expression of FGF-7 promotes epithelial hyperplasia whereas a dominant negative FGFR2iiib promotes the emergence of neuroendocrine phenotype in prostate glands of transgenic mice. Differentiation 70: 624-632.

Foster CS, Dodson A, Karavana V, Smith PH, Ke Y. 2002. Prostatic stem cells. J Pathol 197: 551-565.

Fradet V, Lessard L, Begin LR, Karakiewicz P, Masson AM, Saad F. 2004. Nuclear factor-кB nuclear localization is predictive of biochemical recurrence in patients with positive margin prostate cancer. Clin Cancer Res 10: 8460-8464.

Freedman ML, Haiman CA, Patterson N, McDonald GJ, Tandon A, Waliszewska A, Penney K, Steen RG, Ardlie K, John EM, et al. 2006. Admixture mapping identifies $8 \mathrm{q} 24$ as a prostate cancer risk locus in African-American men. Proc Natl Acad Sci 103: 14068-14073.

Freeman KW, Gangula RD, Welm BE, Ozen M, Foster BA, Rosen JM, Ittmann M, Greenberg NM, Spencer DM. 2003. Conditional activation of fibroblast growth factor receptor (FGFR) 1, but not FGFR2, in prostate cancer cells leads to increased osteopontin induction, extracellular signal-regulated kinase activation, and in vivo proliferation. Cancer Res 63: 6237-6243.

Freestone SH, Marker P, Grace OC, Tomlinson DC, Cunha GR, Harnden P, Thomson AA. 2003. Sonic hedgehog regulates prostatic growth and epithelial differentiation. Dev Biol 264: 352-362.

Frohlich DA, McCabe MT, Arnold RS, Day ML. 2008. The role of Nrf2 in increased reactive oxygen species and DNA damage in prostate tumorigenesis. Oncogene 27: 4353-4362.

Funayama R, Ishikawa F. 2007. Cellular senescence and chromatin structure. Chromosoma 116: 431-440.

Gaddipati JP, McLeod DG, Heidenberg HB, Sesterhenn IA, Finger MJ, Moul JW, Srivastava S. 1994. Frequent detection of codon 877 mutation in the androgen receptor gene in advanced prostate cancers. Cancer Res 54: 2861-2864.

Gao J, Arnold JT, Isaacs JT. 2001. Conversion from a paracrine to an autocrine mechanism of androgen-stimulated growth during malignant transformation of prostatic epithelial cells. Cancer Res 61: 5038-5044.

Gao H, Ouyang X, Banach-Petrosky W, Borowsky AD, Lin Y, Kim M, Lee H, Shih WJ, Cardiff RD, Shen MM, et al. 2004a. 
A critical role for p27kip1 gene dosage in a mouse model of prostate carcinogenesis. Proc Natl Acad Sci 101: 1720417209.

Gao, H., Ouyang, X., Banach-Petrosky, W., Borowsky, A.D., Lin, Y., Kim, M., Lee, H., Shih, W.J., Cardiff, R.D., Shen, M.M., et al. 2004b. A critical role for p27kip1 gene dosage in a mouse model of prostate carcinogenesis. Proc Natl Acad Sci 101: 17204-17209.

Gao N, Ishii K, Mirosevich J, Kuwajima S, Oppenheimer SR, Roberts RL, Jiang M, Yu X, Shappell SB, Caprioli RM, et al. 2005. Forkhead box Al regulates prostate ductal morphogenesis and promotes epithelial cell maturation. Development 132: 3431-3443.

Gao H, Ouyang X, Banach-Petrosky WA, Gerald WL, Shen MM, Abate-Shen C. 2006a. Combinatorial activities of Akt and B-Raf/Erk signaling in a mouse model of androgen-independent prostate cancer. Proc Natl Acad Sci 103: 14477-14482.

Gao H, Ouyang X, Banach-Petrosky WA, Shen MM, Abate-Shen C. 2006b. Emergence of androgen independence at early stages of prostate cancer progression in nkx3.1; pten mice. Cancer Res 66: 7929-7933.

Garcia-Echeverria C, Sellers WR. 2008. Drug discovery approaches targeting the PI3K/Akt pathway in cancer. Oncogene 27: 5511-5526.

Gelmann EP. 2003. Searching for the gatekeeper oncogene of prostate cancer. Crit Rev Oncol Hematol 46: S11-S20. doi: 10.1016/S1040-8428(03)00060-X.

Gelmann EP, Steadman DI, Ma J, Ahronovitz N, Voeller HJ, Swope S, Abbaszadegan M, Brown KM, Strand K, Hayes RB, et al. 2002. Occurrence of NKX3.1 C154T polymorphism in men with and without prostate cancer and studies of its effect on protein function. Cancer Res 62: 2654-2659.

Gil J, Kerai P, Lleonart M, Bernard D, Cigudosa JC, Peters G, Carnero A, Beach D. 2005. Immortalization of primary human prostate epithelial cells by c-Myc. Cancer Res 65: 2179-2185.

Gingrich JR, Barrios RJ, Kattan MW, Nahm HS, Finegold MJ, Greenberg NM. 1997. Androgen-independent prostate cancer progression in the TRAMP model. Cancer Res 57: 4687-4691.

Gioeli D. 2005. Signal transduction in prostate cancer progression. Clin Sci (Lond) 108: 293-308.

Gioeli D, Mandell JW, Petroni GR, Frierson HF Jr, Weber MJ. 1999. Activation of mitogen-activated protein kinase associated with prostate cancer progression. Cancer Res 59: 279-284.

Goldstein AS, Lawson DA, Cheng D, Sun W, Garraway IP, Witte ON. 2008. Trop2 identifies a subpopulation of murine and human prostate basal cells with stem cell characteristics. Proc Natl Acad Sci 105: 20882-20887.

Goldstein AS, Huang J, Guo C, Garraway IP, Witte ON. 2010. Identification of a cell of origin for human prostate cancer. Science 329: 568-571.

Greenberg NM, DeMayo F, Finegold MJ, Medina D, Tilley WD, Aspinall JO, Cunha GR, Donjacour AA, Matusik RJ, Rosen JM. 1995. Prostate cancer in a transgenic mouse. Proc Natl Acad Sci 92: 3439-3443.

Gregory CW, Hamil KG, Kim D, Hall SH, Pretlow TG, Mohler JL, French FS. 1998. Androgen receptor expression in androgen-independent prostate cancer is associated with increased expression of androgen-regulated genes. Cancer Res 58: $5718-5724$

Grignon DJ. 2004. Unusual subtypes of prostate cancer. Mod Pathol 17: 316-327.

Grisanzio C, Signoretti S. 2008. p63 in prostate biology and pathology. J Cell Biochem 103: 1354-1368.

Gschwind A, Fischer OM, Ullrich A. 2004. The discovery of receptor tyrosine kinases: Targets for cancer therapy. Nat Rev Cancer 4: 361-370.
Gudmundsson J, Sulem P, Manolescu A, Amundadottir LT, Gudbjartsson D, Helgason A, Rafnar T, Bergthorsson JT, Agnarsson BA, Baker A, et al. 2007. Genome-wide association study identifies a second prostate cancer susceptibility variant at 8q24. Nat Genet 39: 631-637.

Gudmundsson J, Sulem P, Gudbjartsson DF, Blondal T, Gylfason A, Agnarsson BA, Benediktsdottir KR, Magnusdottir DN, Orlygsdottir G, Jakobsdottir M, et al. 2009. Genome-wide association and replication studies identify four variants associated with prostate cancer susceptibility. Nat Genet 41: 1122-1126.

Guertin DA, Stevens DM, Saitoh M, Kinkel S, Crosby K, Sheen JH, Mullholland DJ, Magnuson MA, Wu H, Sabatini DM. 2009. mTOR complex 2 is required for the development of prostate cancer induced by Pten loss in mice. Cancer Cell 15: 148-159.

Guo Z, Dai B, Jiang T, Xu K, Xie Y, Kim O, Nesheiwat I, Kong X, Melamed J, Handratta VD, et al. 2006. Regulation of androgen receptor activity by tyrosine phosphorylation. Cancer Cell 10: 309-319.

Guo Z, Yang X, Sun F, Jiang R, Linn DE, Chen H, Kong X, Melamed J, Tepper CG, Kung HJ, et al. 2009. A novel androgen receptor splice variant is up-regulated during prostate cancer progression and promotes androgen depletionresistant growth. Cancer Res 69: 2305-2313.

Gurel B, Iwata T, Koh CM, Jenkins RB, Lan F, Van Dang C, Hicks JL, Morgan J, Cornish TC, Sutcliffe S, et al. 2008. Nuclear MYC protein overexpression is an early alteration in human prostate carcinogenesis. Mod Pathol 21: 1156-1167.

Gurel B, Ali TZ, Montgomery EA, Begum S, Hicks J, Goggins M, Eberhart CG, Clark DP, Bieberich CJ, Epstein JI, et al. 2010. NKX3.1 as a marker of prostatic origin in metastatic tumors. Am I Surg Pathol 34: 1097-1105.

Haffner MC, Aryee MJ, Toubaji A, Esopi DM, Albadine R, Gurel B, Isaacs WB, Bova GS, Liu W, Xu J, et al. 2010. Androgeninduced TOP2B-mediated double-strand breaks and prostate cancer gene rearrangements. Nat Genet 42: 668-675.

Haggman MJ, Wojno KJ, Pearsall CP, Macoska JA. 1997. Allelic loss of $8 \mathrm{p}$ sequences in prostatic intraepithelial neoplasia and carcinoma. Urology 50: 643-647.

Haiman CA, Patterson N, Freedman ML, Myers SR, Pike MC, Waliszewska A, Neubauer J, Tandon A, Schirmer C, McDonald GJ, et al. 2007. Multiple regions within 8q24 independently affect risk for prostate cancer. Nat Genet 39: 638-644.

Han G, Buchanan G, Ittmann M, Harris JM, Yu X, Demayo FJ, Tilley W, Greenberg NM. 2005. Mutation of the androgen receptor causes oncogenic transformation of the prostate. Proc Natl Acad Sci 102: 1151-1156.

Hanenszel W, Kurihari M. 1968. Studies of Japanese migrants: Mortality from cancer and other diseases among Japanese in the United States. J Natl Cancer Inst 40: 43-68.

Harzstark AL, Small EJ. 2007. Immunotherapy for prostate cancer using antigen-loaded antigen-presenting cells: APC8015 (Provenge). Expert Opin Biol Ther 7: 1275-1280.

Haverkamp J, Charbonneau B, Ratliff TL. 2008. Prostate inflammation and its potential impact on prostate cancer: A current review. J Cell Biochem 103: 1344-1353.

Hayward SW, Wang Y, Cao M, Hom YK, Zhang B, Grossfeld GD, Sudilovsky D, Cunha GR. 2001. Malignant transformation in a nontumorigenic human prostatic epithelial cell line. Cancer Res 61: 8135-8142.

He HH, Meyer CA, Shin H, Bailey ST, Wei G, Wang Q, Zhang Y, Xu K, Ni M, Lupien M, et al. 2010. Nucleosome dynamics define transcriptional enhancers. Nat Genet 42: 343-347.

Higgins B, Thompson IM. 2004. The prostate cancer prevention trial: Current status. I Urol 171: S15-S18. doi: 10.1097/ 01.ju.0000107440.15626.11. 
Hill RP. 2006. Identifying cancer stem cells in solid tumors: Case not proven. Cancer Res 66: 1891-1895.

Hill R, Song Y, Cardiff RD, Van Dyke T. 2005. Heterogeneous tumor evolution initiated by loss of $\mathrm{pRb}$ function in a preclinical prostate cancer model. Cancer Res 65: 10243-10254.

Hill KM, Kalifa S, Das JR, Bhatti T, Gay M, Williams D, Taliferro-Smith L, De Marzo AM. 2010. The role of PI 3-kinase $\mathrm{p} 110 \beta$ in AKT signally, cell survival, and proliferation in human prostate cancer cells. Prostate 70: 755-764.

Holcomb IN, Grove DI, Kinnunen M, Friedman CL, Gallaher IS, Morgan TM, Sather CL, Delrow JJ, Nelson PS, Lange PH, et al. 2008. Genomic alterations indicate tumor origin and varied metastatic potential of disseminated cells from prostate cancer patients. Cancer Res 68: 5599-5608.

Holzbeierlein J, Lal P, LaTulippe E, Smith A, Satagopan J, Zhang L, Ryan C, Smith S, Scher H, Scardino P, et al. 2004. Gene expression analysis of human prostate carcinoma during hormonal therapy identifies androgen-responsive genes and mechanisms of therapy resistance. Am J Pathol 164: 217-227.

Hooker S, Hernandez W, Chen H, Robbins C, Torres JB, Ahaghotu C, Carpten J, Kittles RA. 2010. Replication of prostate cancer risk loci on 8q24, 11q13, 17q12, 19q33, and Xp11 in African Americans. Prostate 70: 270-275.

Horvath LG, Henshall SM, Lee CS, Kench JG, Golovsky D, Brenner PC, O’Neill GF, Kooner R, Stricker PD, Grygiel JJ, et al. 2005. Lower levels of nuclear $\beta$-catenin predict for a poorer prognosis in localized prostate cancer. Int I Cancer 113: 415-422.

Hu Y, Dobi A, Sreenath T, Cook C, Tadase AY, Ravindranath L, Cullen J, Furusato B, Chen Y, Thangapazham RL, et al. 2008. Delineation of TMPRSS2-ERG splice variants in prostate cancer. Clin Cancer Res 14: 4719-4725.

Hu R, Dunn TA, Wei S, Isharwal S, Veltri RW, Humphreys E, Han M, Partin AW, Vessella RL, Isaacs WB, et al. 2009. Ligand-independent androgen receptor variants derived from splicing of cryptic exons signify hormone-refractory prostate cancer. Cancer Res 69: 16-22.

Huang L, Pu Y, Hu WY, Birch L, Luccio-Camelo D, Yamaguchi T, Prins GS. 2009. The role of Wnt5a in prostate gland development. Dev Biol 328: 188-199.

Hudson DL. 2004. Epithelial stem cells in human prostate growth and disease. Prostate Cancer Prostatic Dis 7: 188-194.

Huggins C, Hodges CV. 1941. The effect of castration, of estrogens, and of androgen injection on serum phosphatase in metastatic carcinoma of prostate. Cancer Res 1: 293-297.

Humphrey PA. 2007. Diagnosis of adenocarcinoma in prostate needle biopsy tissue. I Clin Pathol 60: 35-42.

Iljin K, Wolf M, Edgren H, Gupta S, Kilpinen S, Skotheim RI, Peltola M, Smit F, Verhaegh G, Schalken J, et al. 2006. TMPRSS2 fusions with oncogenic ETS factors in prostate cancer involve unbalanced genomic rearrangements and are associated with HDAC1 and epigenetic reprogramming. Cancer Res 66: 10242-10246.

Isaacs JT. 1985. Control of cell proliferation and cell death in the normal and neoplastic prostate: A stem cell model. In Benign prostatic hyperplasia (ed. CH Rodgers, et al.), pp. 85-94. Department of Helath and Human Services, Washington, DC.

Isaacs JT, Coffey DS. 1981. Adaptation versus selection as the mechanism responsible for the relapse of prostatic cancer to androgen ablation therapy as studied in the Dunning R-3327-H adenocarcinoma. Cancer Res 41: 5070-5075.

Ismail HA, Lessard L, Mes-Masson AM, Saad F. 2004. Expression of NF- $\mathrm{kB}$ in prostate cancer lymph node metastases. Prostate 58: $308-313$.

Iwata T, Schultz D, Hicks J, Hubbard GK, Mutton LN, Lotan TL, Bethel C, Lotz MT, Yegnasubramanian S, Nelson WG, et al.
2010. MYC overexpression induces prostatic intraepithelial neoplasia and loss of $\mathrm{Nkx} 3.1$ in mouse luminal epithelial cells. PLOS ONE 5: e9427. doi: 10.1371/journal.pone.0009427.

Jackson RS II, Franco OE, Bhowmick NA. 2008. Gene targeting to the stroma of the prostate and bone. Differentiation 76: 606-623.

Jenkins RB, Qian J, Lieber MM, Bostwick DG. 1997. Detection of c-myc oncogene amplification and chromosomal anomalies in metastatic prostatic carcinoma by fluorescence in situ hybridization. Cancer Res 57: 524-531.

Jeong JH, Wang Z, Guimaraes AS, Ouyang X, Figueiredo JL, Ding Z, Jiang S, Guney I, Kang GH, Shin E, et al. 2008. BRAF activation initiates but does not maintain invasive prostate adenocarcinoma. PLOS ONE 3: e3949. doi: 10.1371/journal. pone.0003949.

Jia S, Liu Z, Zhang S, Liu P, Zhang L, Lee SH, Zhang J, Signoretti S, Loda M, Roberts TM, et al. 2008. Essential roles of PI(3)Kp110 $\beta$ in cell growth, metabolism and tumorigenesis. Nature 454: 776-779.

Jia L, Landan G, Pomerantz M, Jaschek R, Herman P, Reich D, Yan C, Khalid O, Kantoff P, Oh W, et al. 2009. Functional enhancers at the gene-poor 8q24 cancer-linked locus. PLoS Genet 5: e1000597. doi: 10.1371/journal.pgen.1000597.

Jiang Z, Li C, Fischer A, Dresser K, Woda BA. 2005. Using an AMACR (P504S)/34ßE12/p63 cocktail for the detection of small focal prostate carcinoma in needle biopsy specimens. Am J Clin Pathol 123: 231-236.

Jiang M, Strand DW, Fernandez S, He Y, Yi Y, Birbach A, Qiu Q, Schmid J, Tang DG, Hayward SW. 2010. Functional remodeling of benign human prostatic tissues in vivo by spontaneously immortalized progenitor and intermediate cells. Stem Cells 28: 344-356.

Jiao J, Wang S, Qiao R, Vivanco I, Watson PA, Sawyers CL, Wu H. 2007. Murine cell lines derived from Pten null prostate cancer show the critical role of PTEN in hormone refractory prostate cancer development. Cancer Res 67: 60836091.

Jin C, McKeehan K, Guo W, Jauma S, Ittmann MM, Foster B, Greenberg NM, McKeehan WL, Wang F. 2003. Cooperation between ectopic FGFR1 and depression of FGFR2 in induction of prostatic intraepithelial neoplasia in the mouse prostate. Cancer Res 63: 8784-8790.

Joshua AM, Vukovic B, Braude I, Hussein S, Zielenska M, Srigley J, Evans A, Squire JA. 2007. Telomere attrition in isolated high-grade prostatic intraepithelial neoplasia and surrounding stroma is predictive of prostate cancer. Neoplasia 9: 81-89.

Kader AK, Sun J, Isaacs SD, Wiley KE, Yan G, Kim ST, Fedor H, DeMarzo AM, Epstein JI, Walsh PC, et al. 2009. Individual and cumulative effect of prostate cancer risk-associated variants on clinicopathologic variables in 5,895 prostate cancer patients. Prostate 69: 1195-1205.

Kalaany NY, Sabatini DM. 2009. Tumours with PI3K activation are resistant to dietary restriction. Nature 458: 725-731.

Kaplan-Lefko PJ, Chen TM, Ittmann MM, Barrios RJ, Ayala GE, Huss WJ, Maddison LA, Foster BA, Greenberg NM. 2003. Pathobiology of autochthonous prostate cancer in a preclinical transgenic mouse model. Prostate 55: 219-237.

Karhadkar SS, Bova GS, Abdallah N, Dhara S, Gardner D, Maitra A, Isaacs JT, Berman DM, Beachy PA. 2004. Hedgehog signalling in prostate regeneration, neoplasia and metastasis. Nature 431: 707-712.

Kasper S. 2005. Survey of genetically engineered mouse models for prostate cancer: Analyzing the molecular basis of prostate cancer development, progression, and metastasis. I Cell Biochem 94: 279-297. 
Kasper S. 2008. Stem cells: The root of prostate cancer? I Cell Physiol 216: 332-336.

Ke XS, Qu Y, Rostad K, Li WC, Lin B, Halvorsen OJ, Haukaas SA, Jonassen I, Petersen K, Goldfinger N, et al. 2009. Genome-wide profiling of histone h3 lysine 4 and lysine 27 trimethylation reveals an epigenetic signature in prostate carcinogenesis. PLOS ONE 4: e4687. doi: 10.1371/journal. pone.0004687.

Kelley MR, Cheng L, Foster R, Tritt R, Jiang J, Broshears J, Koch M. 2001. Elevated and altered expression of the multifunctional DNA base excision repair and redox enzyme Ape1/ref1 in prostate cancer. Clin Cancer Res 7: 824-830.

Khalili M, Mutton LN, Gurel B, Hicks JL, De Marzo AM, Bieberich CJ. 2010. Loss of Nkx3.1 expression in bacterial prostatitis. A potential link between inflammation and neoplasia. Am J Pathol 176: 2259-2268

Khandrika L, Kumar B, Koul S, Maroni P, Koul HK. 2009. Oxidative stress in prostate cancer. Cancer Lett 282: 125-136.

Kim MJ, Bhatia-Gaur R, Banach-Petrosky WA, Desai N, Wang Y, Hayward SW, Cunha GR, Cardiff RD, Shen MM, Abate-Shen C. 2002a. Nkx3.1 mutant mice recapitulate early stages of prostate carcinogenesis. Cancer Res 62: 2999-3004.

Kim MJ, Bhatia-Gaur R, Banach-Petrosky WA, Desai N, Wang Y, Hayward SW, Cunha GR, Cardiff RD, Shen MM, Abate-Shen C. 2002 b. Nkx3.1 mutant mice recapitulate early stages of prostate carcinogenesis. Cancer Res 62: 2999-3004.

Kim MJ, Cardiff RD, Desai N, Banach-Petrosky WA, Parsons R, Shen MM, Abate-Shen C. 2002c. Cooperativity of Nkx3.1 and Pten loss of function in a mouse model of prostate carcinogenesis. Proc Natl Acad Sci 99: 2884-2889.

Kim MJ, Cardiff RD, Desai N, Banach-Petrosky WA, Parsons R, Shen MM, Abate-Shen C. 2002d. Cooperativity of Nkx3.1 and Pten loss of function in a mouse model of prostate carcinogenesis. Proc Natl Acad Sci 99: 2884-2889.

Kim J, Eltoum IE, Roh M, Wang J, Abdulkadir SA. 2009. Interactions between cells with distinct mutations in c-MYC and Pten in prostate cancer. PLoS Genet 5: e1000542. doi: 10.1371/journal.pgen.1000542.

King JC, Xu J, Wongvipat J, Hieronymus H, Carver BS, Leung DH, Taylor BS, Sander C, Cardiff RD, Couto SS, et al. 2009. Cooperativity of TMPRSS2-ERG with PI3-kinase pathway activation in prostate oncogenesis. Nat Genet 41: 524-526.

Kinkade CW, Castillo-Martin M, Puzio-Kuter A, Yan J, Foster TH, Gao H, Sun Y, Ouyang X, Gerald WL, Cordon-Cardo C, et al. 2008. Targeting AKT/mTOR and ERK MAPK signaling inhibits hormone-refractory prostate cancer in a preclinical mouse model. J Clin Invest 118: 3051-3064.

Kirsh VA, Hayes RB, Mayne ST, Chatterjee N, Subar AF, Dixon LB, Albanes D, Andriole GL, Urban DA, Peters U. 2006. Supplemental and dietary vitamin E, $\beta$-carotene, and vitamin $\mathrm{C}$ intakes and prostate cancer risk. I Natl Cancer Inst 98: 245-254.

Klein EA, Silverman R. 2008. Inflammation, infection, and prostate cancer. Curr Opin Urol 18: 315-319.

Klezovitch O, Risk M, Coleman I, Lucas JM, Null M, True LD, Nelson PS, Vasioukhin V. 2008. A causal role for ERG in neoplastic transformation of prostate epithelium. Proc Natl Acad Sci 105: 2105-2110.

Knudsen KE, Scher HI. 2009. Starving the addiction: New opportunities for durable suppression of AR signaling in prostate cancer. Clin Cancer Res 15: 4792-4798.

Kobayashi N, Barnard RJ, Said J, Hong-Gonzalez J, Corman DM, $\mathrm{Ku}$ M, Doan NB, Gui D, Elashoff D, Cohen P, et al. 2008. Effect of low-fat diet on development of prostate cancer and Akt phosphorylation in the Hi-Myc transgenic mouse model. Cancer Res 68: 3066-3073.
Koeneman KS, Pan CX, Jin JK, Pyle JMIII, Flanigan RC, Shankey TV, Diaz MO. 1998. Telomerase activity, telomere length, and DNA ploidy in prostatic intraepithelial neoplasia (PIN). J Urol 160: 1533-1539.

Koivisto P, Kononen J, Palmberg C, Tammela T, Hyytinen E, Isola J, Trapman J, Cleutjens K, Noordzij A, Visakorpi T, et al. 1997. Androgen receptor gene amplification: A possible molecular mechanism for androgen deprivation therapy failure in prostate cancer. Cancer Res 57: 314-319.

Kokubo H, Yamada Y, Nishio Y, Fukatsu H, Honda N, Nakagawa A, Saga S, Tsuzuki T, Hara K. 2005. Immunohistochemical study of chromogranin A in Stage D2 prostate cancer. Urology 66: $135-140$.

Kolonel LN. 2001. Fat, meat, and prostate cancer. Epidemiol Rev 23: 72-81.

Kolonel LN, Hankin JH, Whittemore AS, Wu AH, Gallagher RP, Wilkens LR, John EM, Howe GR, Dreon DM, West DW, et al. 2000. Vegetables, fruits, legumes and prostate cancer: A multiethnic case-control study. Cancer Epidemiol Biomarkers Prev 9: 795-804.

Komiya A, Suzuki H, Imamoto T, Kamiya N, Nihei N, Naya Y, Ichikawa T, Fuse H. 2009. Neuroendocrine differentiation in the progression of prostate cancer. Int J Urol 16: 37-44.

Kondo Y, Shen L, Cheng AS, Ahmed S, Boumber Y, Charo C, Yamochi T, Urano T, Furukawa K, Kwabi-Addo B, et al. 2008. Gene silencing in cancer by histone H3 lysine 27 trimethylation independent of promoter DNA methylation. Nat Genet 40: 741-750.

Korenchuk S, Lehr JE. L, MC., Lee YG, Whitney S, Vessella R, Lin DL, Pienta KJ. 2001. VCaP, a cell-based model system of human prostate cancer. In Vivo 15: 163-168.

Korsten H, Ziel-van der Made A, Ma X, van der Kwast T, Trapman J. 2009. Accumulating progenitor cells in the luminal epithelial cell layer are candidate tumor initiating cells in a Pten knockout mouse prostate cancer model. PLoS ONE 4: e5662. doi: 10.1371/journal.pone.0005662.

Kraus S, Gioeli D, Vomastek T, Gordon V, Weber MJ. 2006. Receptor for activated $\mathrm{C}$ kinase 1 (RACK1) and Src regulate the tyrosine phosphorylation and function of the androgen receptor. Cancer Res 66: 11047-11054.

Kunderfranco P, Mello-Grand M, Cangemi R, Pellini S, Mensah A, Albertini V, Malek A, Chiorino G, Catapano CV, Carbone GM. 2010. ETS transcription factors control transcription of EZH2 and epigenetic silencing of the tumor suppressor gene Nkx3.1 in prostate cancer. PLOS ONE 5: e10547. doi: 10.1371/journal.pone.0010547.

Kurita T, Wang YZ, Donjacour AA, Zhao C, Lydon JP, O'Malley BW, Isaacs JT, Dahiya R, Cunha GR. 2001. Paracrine regulation of apoptosis by steroid hormones in the male and female reproductive system. Cell Death Differ 8: 192-200.

Kurita T, Medina RT, Mills AA, Cunha GR. 2004. Role of p63 and basal cells in the prostate. Development 131: 4955-4964.

Lamm M, Catbagan W, Laciak R, Barnett D, Hebner C, Gaffield W, Walterhouse D, Iannaccone P, Bushman W. 2002. Sonic hedgehog activates mesenchymal Glil expression during prostate ductal bud formation. Dev Biol 249: 349-366.

Lapointe J, Li C, Higgins JP, van de Rijn M, Bair E, Montgomery K, Ferrari M, Egevad L, Rayford W, Bergerheim U, et al. 2004. Gene expression profiling identifies clinically relevant subtypes of prostate cancer. Proc Natl Acad Sci 101: 811-816.

Lapointe J, Li C, Giacomini CP, Salari K, Huang S, Wang P, Ferrari M, Hernandez-Boussard T, Brooks JD, Pollack JR. 2007. Genomic profiling reveals alternative genetic pathways of prostate tumorigenesis. Cancer Res 67: 8504-8510.

Lawson DA, Witte ON. 2007. Stem cells in prostate cancer initiation and progression. J Clin Invest 117: 2044-2050. 
Lawson DA, Xin L, Lukacs RU, Cheng D, Witte ON. 2007. Isolation and functional characterization of murine prostate stem cells. Proc Natl Acad Sci 104: 181-186.

Lawson DA, Zong Y, Memarzadeh S, Xin L, Huang J, Witte ON. 2010. Basal epithelial stem cells are efficient targets for prostate cancer initiation. Proc Natl Acad Sci 107: 2610-2615.

Lee SH, Poulogiannis G, Pyne S, Jia S, Zou L, Signoretti S, Loda M, Cantley LC, Roberts TM. 2010. A constitutively activated form of the p110 $\beta$ isoform of PI3-kinase induces prostatic intraepithelial neoplasia in mice. Proc Natl Acad Sci 107: 11002-11007.

Lei Q, Jiao J, Xin L, Chang CJ, Wang S, Gao J, Gleave ME, Witte ON, Liu X, Wu H. 2006. NKX3.1 stabilizes p53, inhibits AKT activation, and blocks prostate cancer initiation caused by PTEN loss. Cancer Cell 9: 367-378.

Leong KG, Wang BE, Johnson L, Gao WQ. 2008. Generation of a prostate from a single adult stem cell. Nature 456: 804-808.

Lessard L, Karakiewicz PI, Bellon-Gagnon P, Alam-Fahmy M, Ismail HA, Mes-Masson AM, Saad F. 2006. Nuclear localization of nuclear factor- $\mathrm{B}$ p 65 in primary prostate tumors is highly predictive of pelvic lymph node metastases. Clin Cancer Res 12: 5741-5745.

Leversha MA, Han J, Asgari Z, Danila DC, Lin O, GonzalezEspinoza R, Anand A, Lilja H, Heller G, Fleisher M, et al. 2009. Fluorescence in situ hybridization analysis of circulating tumor cells in metastatic prostate cancer. Clin Cancer Res 15: 2091-2097.

Li H, Tai BC. 2006. RNASEL gene polymorphisms and the risk of prostate cancer: A meta-analysis. Clin Cancer Res 12: 5713-5719.

Li LC, Carroll PR, Dahiya R. 2005. Epigenetic changes in prostate cancer: Implication for diagnosis and treatment. J Natl Cancer Inst 97: 103-115.

Liao CP, Zhong C, Saribekyan G, Bading J, Park R, Conti PS, Moats R, Berns A, Shi W, Zhou Z, et al. 2007. Mouse models of prostate adenocarcinoma with the capacity to monitor spontaneous carcinogenesis by bioluminescence or fluorescence. Cancer Res 67: 7525-7533.

Lilja H, Ulmert D, Vickers AJ. 2008. Prostate-specific antigen and prostate cancer: Prediction, detection and monitoring. Nat Rev Cancer 8: 268-278.

Lin HK, Hu YC, Lee DK, Chang C. 2004. Regulation of androgen receptor signaling by PTEN (phosphatase and tensin homolog deleted on chromosome 10) tumor suppressor through distinct mechanisms in prostate cancer cells. Mol Endocrinol 18: 2409-2423.

Lin Y, Liu G, Zhang Y, Hu YP, Yu K, Lin C, McKeehan K, Xuan JW, Ornitz DM, Shen MM, et al. 2007. Fibroblast growth factor receptor 2 tyrosine kinase is required for prostatic morphogenesis and the acquisition of strict androgen dependency for adult tissue homeostasis. Development 134: 723-734.

Lin C, Yang L, Tanasa B, Hutt K, Ju BG, Ohgi K, Zhang J, Rose DW, Fu XD, Glass CK, et al. 2009. Nuclear receptor-induced chromosomal proximity and DNA breaks underlie specific translocations in cancer. Cell 139: 1069-1083.

Lin HK, Chen Z, Wang G, Nardella C, Lee SW, Chan CH, Yang WL, Wang J, Egia A, Nakayama KI, et al. 2010. Skp2 targeting suppresses tumorigenesis by Arf-p53-independent cellular senescence. Nature 464: 374-379.

Linja MJ, Savinainen KJ, Saramaki OR, Tammela TL, Vessella RL, Visakorpi T. 2001. Amplification and overexpression of androgen receptor gene in hormone-refractory prostate cancer. Cancer Res 61: 3550-3555.

Lippman SM, Klein EA, Goodman PJ, Lucia MS, Thompson IM, Ford LG, Parnes HL, Minasian LM, Gaziano JM, Hartline JA, et al. 2009. Effect of selenium and vitamin E on risk of prostate cancer and other cancers: The selenium and vitamin E cancer prevention trial (SELECT). JAMA 301: 39-51.

Liu W, Laitinen S, Khan S, Vihinen M, Kowalski J, Yu G, Chen L, Ewing CM, Eisenberger MA, Carducci MA, et al. 2009. Copy number analysis indicates monoclonal origin of lethal metastatic prostate cancer. Nat Med 15: 559-565.

Locke JA, Guns ES, Lubik AA, Adomat HH, Hendy SC, Wood CA, Ettinger SL, Gleave ME, Nelson CC. 2008. Androgen levels increase by intratumoral de novo steroidogenesis during progression of castration-resistant prostate cancer. Cancer Res 68: 6407-6415.

Logothetis CJ, Lin SH. 2005. Osteoblasts in prostate cancer metastasis to bone. Nat Rev Cancer 5: 21-28.

Lu J, Getz G, Miska EA, Alvarez-Saavedra E, Lamb J, Peck D, Sweet-Cordero A, Ebert BL, Mak RH, Ferrando AA, et al. 2005. MicroRNA expression profiles classify human cancers. Nature 435: 834-838.

Luchman HA, Friedman HC, Villemaire ML, Peterson AC, Jirik FR. 2008. Temporally controlled prostate epithelium-specific gene alterations. Genesis 46: 229-234.

Lucia MS, Epstein JI, Goodman PJ, Darke AK, Reuter VE, Civantos F, Tangen CM, Parnes HL, Lippman SM, La Rosa FG, et al. 2007. Finasteride and high-grade prostate cancer in the Prostate Cancer Prevention Trial. I Natl Cancer Inst 99: $1375-1383$.

Luo J, Zha S, Gage WR, Dunn TA, Hicks JL, Bennett CJ, Ewing CM, Platz EA, Ferdinandusse S, Wanders RJ, et al. 2002. $\alpha$-Methylacyl-CoA racemase: A new molecular marker for prostate cancer. Cancer Res 62: 2220-2226.

Luo JL, Tan W, Ricono JM, Korchynskyi O, Zhang M, Gonias SL, Cheresh DA, Karin M. 2007. Nuclear cytokine-activated IKK $\alpha$ controls prostate cancer metastasis by repressing Maspin. Nature 446: 690-694.

Lu-Yao GL, Albertsen PC, Moore DF, Shih W, Lin Y, DiPaola RS, Barry MJ, Zietman A, O'Leary M, Walker-Corkery E, et al. 2009. Outcomes of localized prostate cancer following conservative management. JAMA 302: 1202-1209.

Ma L, Teruya-Feldstein J, Behrendt N, Chen Z, Noda T, Hino O, Cordon-Cardo C, Pandolfi PP. 2005. Genetic analysis of Pten and Tsc2 functional interactions in the mouse reveals asymmetrical haploinsufficiency in tumor suppression. Genes Dev 19: 1779-1786.

Ma X, Ziel-van der Made AC, Autar B, van der Korput HA, Vermeij $M$, van Duijn $P$, Cleutjens KB, de Krijger $R$, Krimpenfort P, Berns A, et al. 2005. Targeted biallelic inactivation of Pten in the mouse prostate leads to prostate cancer accompanied by increased epithelial cell proliferation but not by reduced apoptosis. Cancer Res 65: 5730-5739.

Macintosh CA, Stower M, Reid N, Maitland NJ. 1998. Precise microdissection of human prostate cancers reveals genotypic heterogeneity. Cancer Res 58: 23-28.

Magee JA, Abdulkadir SA, Milbrandt J. 2003. Haploinsufficiency at the Nkx3.1 locus. A paradigm for stochastic, dosagesensitive gene regulation during tumor initiation. Cancer Cell 3: 273-283.

Maitland NJ, Collins AT. 2008. Prostate cancer stem cells: A new target for therapy. J Clin Oncol 26: 2862-2870.

Majumder PK, Yeh JJ, George DJ, Febbo PG, Kum J, Xue Q, Bikoff R, Ma H, Kantoff PW, Golub TR, et al. 2003. Prostate intraepithelial neoplasia induced by prostate restricted Akt activation: The MPAKT model. Proc Natl Acad Sci 100: 7841-7846.

Malik SN, Brattain M, Ghosh PM, Troyer DA, Prihoda T, Bedolla R, Kreisberg JI. 2002. Immunohistochemical demonstration of phospho-Akt in high Gleason grade prostate cancer. Clin Cancer Res 8: 1168-1171. 
Mani RS, Tomlins SA, Callahan K, Ghosh A, Nyati MK, Varambally S, Palanisamy N, Chinnaiyan AM. 2009. Induced chromosomal proximity and gene fusions in prostate cancer. Science 326: 1230.

Marker PC, Donjacour AA, Dahiya R, Cunha GR. 2003. Hormonal, cellular, and molecular control of prostatic development. Dev Biol 253: 165-174.

Markowski MC, Bowen C, Gelmann EP. 2008. Inflammatory cytokines induce phosphorylation and ubiquitination of prostate suppressor protein NKX3.1. Cancer Res 68: 6896-6901.

Marotta LL, Polyak K. 2009. Cancer stem cells: A model in the making. Curr Opin Genet Dev 19: 44-50.

Masumori N, Thomas TZ, Chaurand P, Case T, Paul M, Kasper S, Caprioli RM, Tsukamoto T, Shappell SB, Matusik RJ. 2001. A probasin-large $\mathrm{T}$ antigen transgenic mouse line develops prostate adenocarcinoma and neuroendocrine carcinoma with metastatic potential. Cancer Res 61: 2239-2249.

McMenamin ME, Soung P, Perera S, Kaplan I, Loda M, Sellers WR. 1999. Loss of PTEN expression in paraffin-embedded primary prostate cancer correlates with high Gleason score and advanced stage. Cancer Res 59: 4291-4296.

McNeal JE. 1969. Origin and development of carcinoma in the prostate. Cancer 23: 24-34.

McNeal JE. 1981. The zonal anatomy of the prostate. Prostate 2: 35-49.

McNeal JE. 1988. Normal histology of the prostate. Am I Surg Pathol 12: 619-633.

Meeker AK, Hicks JL, Platz EA, March GE, Bennett CJ, Delannoy MJ, De Marzo AM. 2002. Telomere shortening is an early somatic DNA alteration in human prostate tumorigenesis. Cancer Res 62: 6405-6409.

Meeker AK, Hicks JL, Iacobuzio-Donahue CA, Montgomery EA, Westra WH, Chan TY, Ronnett BM, De Marzo AM. 2004. Telomere length abnormalities occur early in the initiation of epithelial carcinogenesis. Clin Cancer Res 10: 3317-3326.

Mehra R, Han B, Tomlins SA, Wang L, Menon A, Wasco MJ, Shen R, Montie JE, Chinnaiyan AM, Shah RB. 2007a. Heterogeneity of TMPRSS2 gene rearrangements in multifocal prostate adenocarcinoma: Molecular evidence for an independent group of diseases. Cancer Res 67: 7991-7995.

Mehra R, Tomlins SA, Shen R, Nadeem O, Wang L, Wei JT, Pienta KJ, Ghosh D, Rubin MA, Chinnaiyan AM, et al. 2007b. Comprehensive assessment of TMPRSS2 and ETS family gene aberrations in clinically localized prostate cancer. Mod Pathol 20: 538-544.

Mehra R, Tomlins SA, Yu J, Cao X, Wang L, Menon A, Rubin MA, Pienta KJ, Shah RB, Chinnaiyan AM. 2008. Characterization of TMPRSS2-ETS gene aberrations in androgenindependent metastatic prostate cancer. Cancer Res 68: 3584-3590.

Mellinger GT, Gleason D, Bailar J III. 1967. The histology and prognosis of prostatic cancer. J Urol 97: 331-337.

Mellinghoff IK, Vivanco I, Kwon A, Tran C, Wongvipat J, Sawyers CL. 2004. HER2/neu kinase-dependent modulation of androgen receptor function through effects on DNA binding and stability. Cancer Cell 6: 517-527.

Memarzadeh S, Xin L, Mulholland DJ, Mansukhani A, Wu H, Teitell MA, Witte ON. 2007. Enhanced paracrine FGF10 expression promotes formation of multifocal prostate adenocarcinoma and an increase in epithelial androgen receptor. Cancer Cell 12: 572-585.

Migliaccio A, Castoria G, Di Domenico M, de Falco A, Bilancio A, Lombardi M, Barone MV, Ametrano D, Zannini MS, Abbondanza C, et al. 2000. Steroid-induced androgen receptor-oestradiol receptor $\beta$-Src complex triggers prostate cancer cell proliferation. EMBO J 19: 5406-5417.
Min J, Zaslavsky A, Fedele G, McLaughlin SK, Reczek EE, De Raedt T, Guney I, Strochlic DE, Macconaill LE, Beroukhim $\mathrm{R}$, et al. 2010. An oncogene-tumor suppressor cascade drives metastatic prostate cancer by coordinately activating Ras and nuclear factor-кB. Nat Med 16: 286-294.

Minelli A, Bellezza I, Conte C, Culig Z. 2009. Oxidative stressrelated aging: A role for prostate cancer? Biochim Biophys Acta 1795: 83-91.

Mitchell PS, Parkin RK, Kroh EM, Fritz BR, Wyman SK, Pogosova-Agadjanyan EL, Peterson A, Noteboom J, O'Briant KC, Allen A, et al. 2008. Circulating microRNAs as stable blood-based markers for cancer detection. Proc Natl Acad Sci 105: 10513-10518.

Montgomery RB, Mostaghel EA, Vessella R, Hess DL, Kalhorn TF, Higano CS, True LD, Nelson PS. 2008. Maintenance of intratumoral androgens in metastatic prostate cancer: A mechanism for castration-resistant tumor growth. Cancer Res 68: 4447-4454.

Moody SE, Sarkisian CJ, Hahn KT, Gunther EJ, Pickup S, Dugan $\mathrm{KD}$, Innocent $\mathrm{N}$, Cardiff RD, Schnall MD, Chodosh LA. 2002. Conditional activation of $\mathrm{Neu}$ in the mammary epithelium of transgenic mice results in reversible pulmonary metastasis. Cancer Cell 2: 451-461.

Morgan TM, Koreckij TD, Corey E. 2009. Targeted therapy for advanced prostate cancer: Inhibition of the PI3K/Akt/mTOR pathway. Curr Cancer Drug Targets 9: 237-249.

Morse MA, Whelan M. 2010. A year of successful cancer vaccines points to a path forward. Curr Opin Mol Ther 12: 11-13.

Mosquera JM, Perner S, Demichelis F, Kim R, Hofer MD, Mertz KD, Paris PL, Simko J, Collins C, Bismar TA, et al. 2007. Morphological features of TMPRSS2-ERG gene fusion prostate cancer. J Pathol 212: 91-101.

Mosquera JM, Perner S, Genega EM, Sanda M, Hofer MD, Mertz KD, Paris PL, Simko J, Bismar TA, Ayala G, et al. 2008. Characterization of TMPRSS2-ERG fusion high-grade prostatic intraepithelial neoplasia and potential clinical implications. Clin Cancer Res 14: 3380-3385.

Muhlbradt E, Asatiani E, Ortner E, Wang A, Gelmann EP. 2009. NKX3.1 activates expression of insulin-like growth factor binding protein-3 to mediate insulin-like growth factor-I signaling and cell proliferation. Cancer Res 69: 26152622.

Mulholland DJ, Dedhar S, Wu H, Nelson CC. 2006. PTEN and GSK3 $\beta$ : Key regulators of progression to androgenindependent prostate cancer. Oncogene 25: 329-337.

Mulholland DI, Xin L, Morim A, Lawson D, Witte O, Wu H. 2009. Lin $^{-} \mathrm{Sca}^{-} 1^{+} \mathrm{CD} 49 \mathrm{f}^{\text {high }}$ stem/progenitors are tumorinitiating cells in the Pten-null prostate cancer model. Cancer Res 69: 8555-8562.

Nakai Y, Nelson WG, De Marzo AM. 2007. The dietary charred meat carcinogen 2-amino-1-methyl-6-phenylimidazo[4,5b]pyridine acts as both a tumor initiator and promoter in the rat ventral prostate. Cancer Res 67: 1378-1384.

Nakayama M, Gonzalgo ML, Yegnasubramanian S, Lin X, De Marzo AM, Nelson WG. 2004. GSTP1 CpG island hypermethylation as a molecular biomarker for prostate cancer. J Cell Biochem 91: 540-552.

Nardella C, Chen Z, Salmena L, Carracedo A, Alimonti A, Egia A, Carver B, Gerald W, Cordon-Cardo C, Pandolfi PP. 2008. Aberrant Rheb-mediated mTORC1 activation and Pten haploinsufficiency are cooperative oncogenic events. Genes Dev 22: 2172-2177.

Nelson WG. 2007. Prostate cancer prevention. Curr Opin Urol 17: 157-167.

Nelson WG, Yegnasubramanian S, Agoston AT, Bastian PJ, Lee BH, Nakayama M, De Marzo AM. 2007. Abnormal DNA 
methylation, epigenetics, and prostate cancer. Front Biosci 12: 4254-4266.

Nelson WG, De Marzo AM, Yegnasubramanian S. 2009. Epigenetic alterations in human prostate cancers. Endocrinology 150: 3991-4002.

Niu Y, Altuwaijri S, Lai KP, Wu CT, Ricke WA, Messing EM, Yao J, Yeh S, Chang C. 2008a. Androgen receptor is a tumor suppressor and proliferator in prostate cancer. Proc Natl Acad Sci 105: 12182-12187.

Niu Y, Altuwaijri S, Yeh S, Lai KP, Yu S, Chuang KH, Huang SP, Lardy H, Chang C. 2008b. Targeting the stromal androgen receptor in primary prostate tumors at earlier stages. Proc Natl Acad Sci 105: 12188-12193.

Ohori M, Wheeler TM, Scardino PT. 1994. The New American Joint Committee on Cancer and International Union Against Cancer TNM classification of prostate cancer. Clinicopathologic correlations. Cancer 74: 104-114.

Olumi AF, Grossfeld GD, Hayward SW, Carroll PR, Tlsty TD, Cunha GR. 1999. Carcinoma-associated fibroblasts direct tumor progression of initiated human prostatic epithelium. Cancer Res 59: 5002-5011.

Ornstein DK, Cinquanta M, Weiler S, Duray PH, Emmert-Buck MR, Vocke CD, Linehan WM, Ferretti JA. 2001. Expression studies and mutational analysis of the androgen regulated homeobox gene NKX3.1 in benign and malignant prostate epithelium. J Urol 165: 1329-1334.

Ouyang X, DeWeese TL, Nelson WG, Abate-Shen C. 2005. Lossof-function of $\mathrm{Nkx} 3.1$ promotes increased oxidative damage in prostate carcinogenesis. Cancer Res 65: 6773-6779.

Ozen M, Creighton CJ, Ozdemir M, Ittmann M. 2008. Widespread deregulation of microRNA expression in human prostate cancer. Oncogene 27: 1788-1793.

Palanisamy N, Ateeq B, Kalyana-Sundaram S, Pflueger D, Ramnarayanan K, Shankar S, Han B, Cao Q, Cao X, Suleman $\mathrm{K}$, et al. 2010. Rearrangements of the RAF kinase pathway in prostate cancer, gastric cancer and melanoma. Nat Med 16: $793-798$.

Pardal R, Clarke MF, Morrison SJ. 2003. Applying the principles of stem-cell biology to cancer. Nat Rev Cancer 3: 895-902.

Patrawala L, Calhoun T, Schneider-Broussard R, Li H, Bhatia B Tang S, Reilly JG, Chandra D, Zhou J, Claypool K, et al. 2006. Highly purified $\mathrm{CD} 44^{+}$prostate cancer cells from xenograft human tumors are enriched in tumorigenic and metastatic progenitor cells. Oncogene 25: 1696-1708.

Patrawala L, Calhoun-Davis T, Schneider-Broussard R, Tang DG. 2007. Hierarchical organization of prostate cancer cells in xenograft tumors: The $\mathrm{CD} 44^{+} \alpha 2 \beta 1^{+}$cell population is enriched in tumor-initiating cells. Cancer Res 67: 6796-6805.

Paweletz CP, Charboneau L, Bichsel VE, Simone NL, Chen T, Gillespie JW, Emmert-Buck MR, Roth MJ, Petricoin IE, Liotta LA. 2001. Reverse phase protein microarrays which capture disease progression show activation of pro-survival pathways at the cancer invasion front. Oncogene 20: 19811989.

Pearson HB, Phesse TJ, Clarke AR. 2009. K-ras and Wnt signaling synergize to accelerate prostate tumorigenesis in the mouse. Cancer Res 69: 94-101.

Peehl DM. 2005. Primary cell cultures as models of prostate cancer development. Endocr Relat Cancer 12: 19-47.

Perner S, Demichelis F, Beroukhim R, Schmidt FH, Mosquera JM, Setlur S, Tchinda I, Tomlins SA, Hofer MD, Pienta KG, et al. 2006. TMPRSS2:ERG fusion-associated deletions provide insight into the heterogeneity of prostate cancer. Cancer Res 66: 8337-8341.

Petrylak DP. 2007. New paradigms for advanced prostate cancer. Rev Urol 9: S3-S12.
Petrylak DP, Tangen CM, Hussain MH, Lara PN Jr, Jones JA, Taplin ME, Burch PA, Berry D, Moinpour C, Kohli M, et al. 2004. Docetaxel and estramustine compared with mitoxantrone and prednisone for advanced refractory prostate cancer. N Engl J Med 351: 1513-1520.

Ploussard G, de la Taille A. 2010. Urine biomarkers in prostate cancer. Nat Rev Urol 7: 101-109.

Podlasek CA, Barnett DH, Clemens JQ, Bak PM, Bushman W. 1999. Prostate development requires Sonic hedgehog expressed by the urogenital sinus epithelium. Dev Biol 209: 28-39.

Podsypanina K, Ellenson LH, Nemes A, Gu J, Tamura M, Yamada KM, Cordon-Cardo C, Catoretti G, Fisher PE, Parsons R. 1999. Mutation of Pten/Mmacl in mice causes neoplasia in multiple organ systems. Proc Natl Acad Sci 96: 1563-1568.

Poliseno L, Salmena L, Riccardi L, Fornari A, Song MS, Hobbs RM, Sportoletti P, Varmeh S, Egia A, Fedele G, et al. 2010a. Identification of the miR-106b 25 microRNA cluster as a proto-oncogenic PTEN-targeting intron that cooperates with its host gene MCM7 in transformation. Sci Signal 3: ra29. doi: 10.1126/scisignal.2000594.

Poliseno L, Salmena L, Zhang J, Carver B, Haveman WJ, Pandolfi PP. 2010b. A coding-independent function of gene and pseudogene mRNAs regulates tumour biology. Nature 465: 1033-1038.

Pomerantz MM, Beckwith CA, Regan MM, Wyman SK, Petrovics G, Chen Y, Hawksworth DJ, Schumacher FR, Mucci L, Penney KL, et al. 2009. Evaluation of the 8q24 prostate cancer risk locus and MYC expression. Cancer Res 69: 5568-5574.

Porkka KP, Pfeiffer MJ, Waltering KK, Vessella RL, Tammela TL, Visakorpi T. 2007. MicroRNA expression profiling in prostate cancer. Cancer Res 67: 6130-6135.

Prins GS, Putz O. 2008. Molecular signaling pathways that regulate prostate gland development. Differentiation 76: 641-659.

Pritchard CC, Nelson PS. 2008. Gene expression profiling in the developing prostate. Differentiation 76: 624-640.

Pritchard C, Mecham B, Dumpit R, Coleman I, Bhattacharjee M, Chen Q, Sikes RA, Nelson PS. 2009. Conserved gene expression programs integrate mammalian prostate development and tumorigenesis. Cancer Res 69: 1739-1747.

Quintana E, Shackleton M, Sabel MS, Fullen DR, Johnson TM, Morrison SJ. 2008. Efficient tumour formation by single human melanoma cells. Nature 456: 593-598.

Ratnacaram CK, Teletin M, Jiang M, Meng X, Chambon P, Metzger D. 2008. Temporally controlled ablation of PTEN in adult mouse prostate epithelium generates a model of invasive prostatic adenocarcinoma. Proc Natl Acad Sci 105: 2521-2526.

Reya T, Morrison SJ, Clarke MF, Weissman IL. 2001. Stem cells, cancer, and cancer stem cells. Nature 414: 105-111.

Richardson GD, Robson CN, Lang SH, Neal DE, Maitland NJ, Collins AT. 2004. CD133, a novel marker for human prostatic epithelial stem cells. J Cell Sci 117: 3539-3545.

Robzyk K, Oen H, Buchanan G, Butler LM, Tilley WD, Mandal AK, Rosen N, Caplan AJ. 2007. Uncoupling of hormonedependence from chaperone-dependence in the $\mathrm{L} 701 \mathrm{H} \mathrm{mu}-$ tation of the androgen receptor. Mol Cell Endocrinol 268: $67-74$.

Rosen JM, Jordan CT. 2009. The increasing complexity of the cancer stem cell paradigm. Science 324: 1670-1673.

Rossi DJ, Jamieson CH, Weissman IL. 2008. Stem cells and the pathways to aging and cancer. Cell 132: 681-696.

Rouzier C, Haudebourg J, Carpentier X, Valerio L, Amiel J, Michiels JF, Pedeutour F. 2008. Detection of the TMPRSS2ETS fusion gene in prostate carcinomas: Retrospective analysis of 55 formalin-fixed and paraffin-embedded samples with clinical data. Cancer Genet Cytogenet 183: 21-27. 
Sakr WA, Grignon DJ, Crissman JD, Heilbrun LK, Cassin BJ, Pontes JJ, Haas GP. 1994. High grade prostatic intraepithelial neoplasia (HGPIN) and prostatic adenocarcinoma between the ages of 20-69: An autopsy study of 249 cases. In Vivo 8: 439-443.

Salmena L, Carracedo A, Pandolfi PP. 2008. Tenets of PTEN tumor suppression. Cell 133: 403-414.

Sanchez P, Hernandez AM, Stecca B, Kahler AJ, DeGueme AM, Barrett A, Beyna M, Datta MW, Datta S, Ruiz i Altaba A. 2004. Inhibition of prostate cancer proliferation by interference with SONIC HEDGEHOG-GLIl signaling. Proc Natl Acad Sci 101: 12561-12566.

Saramaki OR, Tammela TL, Martikainen PM, Vessella RL, Visakorpi T. 2006. The gene for polycomb group protein enhancer of zeste homolog 2 (EZH2) is amplified in late-stage prostate cancer. Genes Chromosomes Cancer 45: 639-645.

Saramaki OR, Harjula AE, Martikainen PM, Vessella RL, Tammela TL, Visakorpi T. 2008. TMPRSS2:ERG fusion identifies a subgroup of prostate cancers with a favorable prognosis. Clin Cancer Res 14: 3395-3400.

Sartor AO, Hricak H, Wheeler TM, Coleman J, Penson DF, Carroll PR, Rubin MA, Scardino PT. 2008. Evaluating localized prostate cancer and identifying candidates for focal therapy. Urology 72: S12-S24. doi: 10.1016/j.urology.2008.10.004.

Sato K, Qian J, Slezak JM, Lieber MM, Bostwick DG, Bergstralh EJ, Jenkins RB. 1999. Clinical significance of alterations of chromosome 8 in high-grade, advanced, nonmetastatic prostate carcinoma. J Natl Cancer Inst 91: 1574-1580.

Sawyers CL. 2003. Will mTOR inhibitors make it as cancer drugs? Cancer Cell 4: 343-348.

Schaeffer EM, Marchionni L, Huang Z, Simons B, Blackman A, Yu W, Parmigiani G, Berman DM. 2008. Androgen-induced programs for prostate epithelial growth and invasion arise in embryogenesis and are reactivated in cancer. Oncogene 27: 7180-7191.

Schaid DJ. 2004. The complex genetic epidemiology of prostate cancer. Hum Mol Genet 13: R103-R121. doi: 10.1093/hmg/ ddh072.

Scher HI, Beer TM, Higano CS, Anand A, Taplin ME, Efstathiou E, Rathkopf D, Shelkey J, Yu EY, Alumkal J, et al. 2010. Antitumour activity of MDV3100 in castration-resistant prostate cancer: A phase 1-2 study. Lancet 375: 1437-1446.

Schlaberg R, Choe DJ, Brown KR, Thaker HM, Singh IR. 2009. $\mathrm{XMRV}$ is present in malignant prostatic epithelium and is associated with prostate cancer, especially high-grade tumors. Proc Natl Acad Sci 106: 16351-16356.

Schmitz M, Grignard G, Margue C, Dippel W, Capesius C, Mossong J, Nathan M, Giacchi S, Scheiden R, Kieffer N. 2007. Complete loss of PTEN expression as a possible early prognostic marker for prostate cancer metastasis. Int $I$ Cancer 120: 1284-1292.

Schneider A, Brand T, Zweigerdt R, Arnold H. 2000. Targeted disruption of the Nkx3.1 gene in mice results in morphogenetic defects of minor salivary glands: Parallels to glandular duct morphogenesis in prostate. Mech Dev 95: 163-174.

Sfanos KS, Sauvageot J, Fedor HL, Dick JD, De Marzo AM, Isaacs WB. 2008. A molecular analysis of prokaryotic and viral DNA sequences in prostate tissue from patients with prostate cancer indicates the presence of multiple and diverse microorganisms. Prostate 68: 306-320.

Shackleton M, Quintana E, Fearon ER, Morrison SJ. 2009. Heterogeneity in cancer: Cancer stem cells versus clonal evolution. Cell 138: 822-829.

Shah RB, Mehra R, Chinnaiyan AM, Shen R, Ghosh D, Zhou M, Macvicar GR, Varambally S, Harwood J, Bismar TA, et al. 2004. Androgen-independent prostate cancer is a heteroge- neous group of diseases: Lessons from a rapid autopsy program. Cancer Res 64: 9209-9216.

Shappell SB, Thomas GV, Roberts RL, Herbert R, Ittmann MM, Rubin MA, Humphrey PA, Sundberg JP, Rozengurt N, Barrios $\mathrm{R}$, et al. 2004. Prostate pathology of genetically engineered mice: Definitions and classification. The consensus report from the Bar Harbor meeting of the Mouse Models of Human Cancer Consortium Prostate Pathology Committee. Cancer Res 64: 2270-2305.

Sharifi N, Kawasaki BT, Hurt EM, Farrar WL. 2006. Stem cells in prostate cancer: Resolving the castrate-resistant conundrum and implications for hormonal therapy. Cancer Biol Ther 5: 901-906.

Shaw A, Papadopoulos J, Johnson C, Bushman W. 2006. Isolation and characterization of an immortalized mouse urogenital sinus mesenchyme cell line. Prostate 66: 13471358.

Shaw A, Gipp J, Bushman W. 2009. The Sonic Hedgehog pathway stimulates prostate tumor growth by paracrine signaling and recapitulates embryonic gene expression in tumor myofibroblasts. Oncogene 28: 4480-4490.

Shen MM, Abate-Shen C. 2007. Pten inactivation and the emergence of androgen-independent prostate cancer. Cancer Res 67: 6535-6538.

Shi XB, Xue L, Yang J, Ma AH, Zhao J, Xu M, Tepper CG, Evans CP, Kung HJ, deVere White RW. 2007. An androgen-regulated miRNA suppresses Bakl expression and induces androgenindependent growth of prostate cancer cells. Proc Natl Acad Sci 104: 19983-19988.

Shiraishi T, Watanabe M, Matsuura H, Kusano I, Yatani R, Stemmermann GN. 1994. The frequency of latent prostatic carcinoma in young males: The Japanese experience. In Vivo 8: $445-447$.

Shmelkov SV, Butler JM, Hooper AT, Hormigo A, Kushner J, Milde T, St Clair R, Baljevic M, White I, Jin DK, et al. 2008. CD133 expression is not restricted to stem cells, and both $\mathrm{CD}_{133^{+}}$and $\mathrm{CD} 133^{-}$metastatic colon cancer cells initiate tumors. J Clin Invest 118: 2111-2120.

Silverman RH, Nguyen C, Weight CJ, Klein EA. 2010. The human retrovirus XMRV in prostate cancer and chronic fatigue syndrome. Nat Rev Urol 7: 392-402.

Singh AS, Figg WD. 2005. In vivo models of prostate cancer metastasis to bone. J Urol 174: 820-826.

Singh D, Febbo PG, Ross K, Jackson DG, Manola J, Ladd C, Tamayo P, Renshaw AA, D'Amico AV, Richie JP, et al. 2002. Gene expression correlates of clinical prostate cancer behavior. Cancer Cell 1: 203-209.

Sircar K, Yoshimoto M, Monzon FA, Koumakpayi IH, Katz RL, Khanna A, Alvarez K, Chen G, Darnel AD, Aprikian AG, et al. 2009. PTEN genomic deletion is associated with p-Akt and AR signalling in poorer outcome, hormone refractory prostate cancer. I Pathol 218: 505-513.

Sobel RE, Sadar MD. 2005a. Cell lines used in prostate cancer research: A compendium of old and new lines-Part 1. J Urol 173: 342-359.

Sobel RE, Sadar MD. 2005b. Cell lines used in prostate cancer research: A compendium of old and new lines-Part 2. J Urol 173: 360-372.

Sommerfeld HJ, Meeker AK, Piatyszek MA, Bova GS, Shay JW, Coffey DS. 1996. Telomerase activity: A prevalent marker of malignant human prostate tissue. Cancer Res 56: 218-222.

Song Z, Wu X, Powell WC, Cardiff RD, Cohen MB, Tin RT, Matusik RJ, Miller GJ, Roy-Burman P. 2002. Fibroblast growth factor 8 isoform B overexpression in prostate epithelium: A new mouse model for prostatic intraepithelial neoplasia. Cancer Res 62: 5096-5105. 
Song H, Zhang B, Watson MA, Humphrey PA, Lim H, Milbrandt J. 2009. Loss of Nkx3.1 leads to the activation of discrete downstream target genes during prostate tumorigenesis. Oncogene 28: 3307-3319.

Sotelo J, Esposito D, Duhagon MA, Banfield K, Mehalko J, Liao H, Stephens RM, Harris TJ, Munroe DJ, Wu X. 2010. Longrange enhancers on 8q24 regulate c-Myc. Proc Natl Acad Sci 107: 3001-3005.

Sreekumar A, Poisson LM, Rajendiran TM, Khan AP, Cao Q, Yu J, Laxman B, Mehra R, Lonigro RJ, Li Y, et al. 2009. Metabolomic profiles delineate potential role for sarcosine in prostate cancer progression. Nature 457: 910-914.

Stanbrough M, Leav I, Kwan PW, Bubley GJ, Balk SP. 2001. Prostatic intraepithelial neoplasia in mice expressing an androgen receptor transgene in prostate epithelium. Proc Natl Acad Sci 98: 10823-10828.

Stanbrough M, Bubley GJ, Ross K, Golub TR, Rubin MA, Penning TM, Febbo PG, Balk SP. 2006. Increased expression of genes converting adrenal androgens to testosterone in androgen-independent prostate cancer. Cancer Res 66: 28152825.

Stanfel MN, Moses KA, Carson JA, Zimmer DB, DeMayo F, Schwartz RJ, Zimmer WE. 2006. Expression of an Nkx3.1CRE gene using ROSA26 reporter mice. Genesis 44: 550555 .

Steinkamp MP, O'Mahony OA, Brogley M, Rehman H, Lapensee EW, Dhanasekaran S, Hofer MD, Kuefer R, Chinnaiyan A, Rubin MA, et al. 2009. Treatment-dependent androgen receptor mutations in prostate cancer exploit multiple mechanisms to evade therapy. Cancer Res 69: 4434-4442.

Su IH, Dobenecker MW, Dickinson E, Oser M, Basavaraj A, Marqueron R, Viale A, Reinberg D, Wulfing C, Tarakhovsky A. 2005. Polycomb group protein ezh2 controls actin polymerization and cell signaling. Cell 121: 425-436.

Sun T, Wang Q, Balk S, Brown M, Lee GS, Kantoff P. 2009. The role of microRNA-221 and microRNA-222 in androgenindependent prostate cancer cell lines. Cancer Res 69: 3356-3363.

Swalwell JI, Vocke CD, Yang Y, Walker JR, Grouse L, Myers SH, Gillespie JW, Bostwick DG, Duray PH, Linehan WM, et al. 2002. Determination of a minimal deletion interval on chromosome band $8 \mathrm{p} 21$ in sporadic prostate cancer. Genes Chromosomes Cancer 33: 201-205.

Tanaka M, Komuro I, Inagaki H, Jenkins NA, Copeland NG, Izumo S. 2000. Nkx3.1, a murine homolog of Drosophila bagpipe, regulates epithelial ductal branching and proliferation of the prostate and palatine glands. Dev Dyn 219: 248260.

Tannock IF, de Wit R, Berry WR, Horti J, Pluzanska A, Chi KN, Oudard S, Theodore C, James ND, Turesson I, et al. 2004 Docetaxel plus prednisone or mitoxantrone plus prednisone for advanced prostate cancer. N Engl J Med 351: 1502-1512.

Taplin ME, Balk SP. 2004. Androgen receptor: A key molecule in the progression of prostate cancer to hormone independence. I Cell Biochem 91: 483-490.

Taplin ME, Bubley GJ, Shuster TD, Frantz ME, Spooner AE, Ogata GK, Keer HN, Balk SP. 1995. Mutation of the androgenreceptor gene in metastatic androgen-independent prostate cancer. N Engl J Med 332: 1393-1398.

Taplin ME, Rajeshkumar B, Halabi S, Werner CP, Woda BA, Picus J, Stadler W, Hayes DF, Kantoff PW, Vogelzang NJ, et al. 2003. Androgen receptor mutations in androgen-independent prostate cancer: Cancer and Leukemia Group B Study 9663. J Clin Oncol 21: 2673-2678.

Taylor BS, Schultz N, Hieronymus H, Gopalan A, Xiao Y, Carver BS, Arora VK, Kaushik P, Cerami E, Reva B, et al. 2010.
Integrative genomic profiling of human prostate cancer. Cancer Cell 18: 11-22.

Thalmann, G.N., Sikes, R.A., Wu, T.T., Degeorges, A., Chang, S.M., Ozen, M., Pathak, S., Chung, L.W. 2000. LNCaP progression model of human prostate cancer: Androgenindependence and osseous metastasis. Prostate 44: 91-103.

Thomas GV, Horvath S, Smith BL, Crosby K, Lebel LA, Schrage M, Said J, De Kernion J, Reiter RE, Sawyers CL. 2004. Antibody-based profiling of the phosphoinositide 3-kinase pathway in clinical prostate cancer. Clin Cancer Res 10: 8351-8356.

Thomas G, Jacobs KB, Yeager M, Kraft P, Wacholder S, Orr N, Yu K, Chatterjee N, Welch R, Hutchinson A, et al. 2008. Multiple loci identified in a genome-wide association study of prostate cancer. Nat Genet 40: 310-315.

Thomsen MK, Butler CM, Shen MM, Swain A. 2008. Sox9 is required for prostate development. Dev Biol 316: 302-311.

Tilley WD, Buchanan G, Hickey TE, Bentel JM. 1996. Mutations in the androgen receptor gene are associated with progression of human prostate cancer to androgen independence. Clin Cancer Res 2: 277-285.

Timms BG. 2008. Prostate development: A historical perspective. Differentiation 76: 565-577.

Titus MA, Schell MJ, Lih FB, Tomer KB, Mohler JL. 2005. Testosterone and dihydrotestosterone tissue levels in recurrent prostate cancer. Clin Cancer Res 11: 4653-4657.

Tomlins SA, Rhodes DR, Perner S, Dhanasekaran SM, Mehra R, Sun XW, Varambally S, Cao X, Tchinda J, Kuefer R, et al. 2005. Recurrent fusion of TMPRSS2 and ETS transcription factor genes in prostate cancer. Science 310: 644-648.

Tomlins SA, Laxman B, Dhanasekaran SM, Helgeson BE, Cao X, Morris DS, Menon A, Jing X, Cao Q, Han B, et al. 2007a. Distinct classes of chromosomal rearrangements create oncogenic ETS gene fusions in prostate cancer. Nature 448: 595-599.

Tomlins SA, Mehra R, Rhodes DR, Cao X, Wang L, Dhanasekaran SM, Kalyana-Sundaram S, Wei JT, Rubin MA, Pienta KJ, et al. $2007 \mathrm{~b}$. Integrative molecular concept modeling of prostate cancer progression. Nat Genet 39: 41-51.

Tomlins SA, Laxman B, Varambally S, Cao X, Yu J, Helgeson BE, Cao Q, Prensner JR, Rubin MA, Shah RB, et al. 2008a. Role of the TMPRSS2-ERG gene fusion in prostate cancer. Neoplasia 10: $177-188$.

Tomlins SA, Rhodes DR, Yu J, Varambally S, Mehra R, Perner S, Demichelis F, Helgeson BE, Laxman B, Morris DS, et al. 2008b. The role of SPINK1 in ETS rearrangement-negative prostate cancers. Cancer Cell 13: 519-528.

Tran C, Ouk S, Clegg NJ, Chen Y, Watson PA, Arora V, Wongvipat J, Smith-Jones PM, Yoo D, Kwon A, et al. 2009. Development of a second-generation antiandrogen for treatment of advanced prostate cancer. Science 324: 787-790.

Trotman LC, Niki M, Dotan ZA, Koutcher JA, Di Cristofano A, Xiao A, Khoo AS, Roy-Burman P, Greenberg NM, Van Dyke T, et al. 2003. Pten dose dictates cancer progression in the prostate. PLOS Biol 1: E59. doi: 10.1371/journal.pbio.0000059.

Trotman LC, Alimonti A, Scaglioni PP, Koutcher JA, CordonCardo C, Pandolfi PP. 2006. Identification of a tumour suppressor network opposing nuclear Akt function. Nature 441: $523-527$.

True L, Coleman I, Hawley S, Huang CY, Gifford D, Coleman R, Beer TM, Gelmann E, Datta M, Mostaghel E, et al. 2006. A molecular correlate to the Gleason grading system for prostate adenocarcinoma. Proc Natl Acad Sci 103: 1099110996.

Urisman A, Molinaro RJ, Fischer N, Plummer SJ, Casey G, Klein EA, Malathi K, Magi-Galluzzi C, Tubbs RR, Ganem D, et al. 
2006. Identification of a novel gammaretrovirus in prostate tumors of patients homozygous for R462Q RNASEL variant. PLOS Pathog 2: e25. doi: 10/1371/journal.ppat.0020025.

Uzgare AR, Isaacs JT. 2004. Enhanced redundancy in Akt and mitogen-activated protein kinase-induced survival of malignant versus normal prostate epithelial cells. Cancer Res 64: 6190-6199.

van Bokhoven A, Varella-Garcia M, Korch C, Miller GJ. 2001. TSU-Pr1 and JCA-1 cells are derivatives of T24 bladder carcinoma cells and are not of prostatic origin. Cancer Res 61: 6340-6344.

van Leenders GJ, Schalken JA. 2003. Epithelial cell differentiation in the human prostate epithelium: Implications for the pathogenesis and therapy of prostate cancer. Crit Rev Oncol Hematol 46: S3-S10. doi: 10.1016/S1040-8428(03)00059-3.

Varambally S, Dhanasekaran SM, Zhou M, Barrette TR, KumarSinha C, Sanda MG, Ghosh D, Pienta KJ, Sewalt RG, Otte $\mathrm{AP}$, et al. 2002. The polycomb group protein EZH2 is involved in progression of prostate cancer. Nature 419: 624-629.

Varambally S, Cao Q, Mani RS, Shankar S, Wang X, Ateeq B, Laxman B, Cao X, Jing X, Ramnarayanan K, et al. 2008. Genomic loss of microRNA-101 leads to overexpression of histone methyltransferase EZH2 in cancer. Science 322: 1695-1699.

Verhagen PC, van Duijn PW, Hermans KG, Looijenga LH, van Gurp RJ, Stoop H, van der Kwast TH, Trapman J. 2006. The PTEN gene in locally progressive prostate cancer is preferentially inactivated by bi-allelic gene deletion. I Pathol 208: 699-707.

Visakorpi T, Hyytinen E, Koivisto P, Tanner M, Keinanen R, Palmberg C, Palotie A, Tammela T, Isola J, Kallioniemi OP. 1995. In vivo amplification of the androgen receptor gene and progression of human prostate cancer. Nat Genet 9: 401-406.

Visvader JE. 2009. Keeping abreast of the mammary epithelial hierarchy and breast tumorigenesis. Genes Dev 23: 2563-2577.

Visvader JE, Lindeman GJ. 2008. Cancer stem cells in solid tumours: Accumulating evidence and unresolved questions. Nat Rev Cancer 8: 755-768.

Vocke CD, Pozzatti RO, Bostwick DG, Florence CD, Jennings SB, Strup SE, Duray PH, Liotta LA, Emmert-Buck MR, Linehan WM. 1996. Analysis of 99 microdissected prostate carcinomas reveals a high frequency of allelic loss on chromosome 8p12-21. Cancer Res 56: 2411-2416.

Voeller HJ, Augustus M, Madike V, Bova GS, Carter KC, Gelmann EP. 1997. Coding region of NKX3.1, a prostatespecific homeobox gene on $8 \mathrm{p} 21$, is not mutated in human prostate cancers. Cancer Res 57: 4455-4459.

Volinia S, Calin GA, Liu CG, Ambs S, Cimmino A, Petrocca F, Visone R, Iorio M, Roldo C, Ferracin $M$, et al. 2006. A microRNA expression signature of human solid tumors defines cancer gene targets. Proc Natl Acad Sci 103: 2257-2261.

Vukovic B, Park PC, Al-Maghrabi J, Beheshti B, Sweet J, Evans A, Trachtenberg J, Squire J. 2003. Evidence of multifocality of telomere erosion in high-grade prostatic intraepithelial neoplasia (HPIN) and concurrent carcinoma. Oncogene 22: 1978-1987.

Wang SI, Parsons R, Ittmann M. 1998. Homozygous deletion of the PTEN tumor suppressor gene in a subset of prostate adenocarcinomas. Clin Cancer Res 4: 811-815.

Wang Y, Hayward SW, Donjacour AA, Young P, Jacks T, Sage I, Dahiya R, Cardiff RD, Day ML, Cunha GR. 2000. Sex hormone-induced carcinogenesis in $\mathrm{Rb}$-deficient prostate tissue. Cancer Res 60: 6008-6017.

Wang S, Gao J, Lei Q, Rozengurt N, Pritchard C, Jiao J, Thomas GV, Li G, Roy-Burman P, Nelson PS, et al. 2003. Prostate- specific deletion of the murine Pten tumor suppressor gene leads to metastatic prostate cancer. Cancer Cell 4: 209-221.

Wang F, McKeehan K, Yu C, Ittmann M, McKeehan WL. 2004. Chronic activity of ectopic type 1 fibroblast growth factor receptor tyrosine kinase in prostate epithelium results in hyperplasia accompanied by intraepithelial neoplasia. Prostate 58: 1-12.

Wang J, Cai Y, Ren C, Ittmann M. 2006. Expression of variant TMPRSS2/ERG fusion messenger RNAs is associated with aggressive prostate cancer. Cancer Res 66: 8347-8351.

Wang S, Garcia AJ, Wu M, Lawson DA, Witte ON, Wu H. 2006. Pten deletion leads to the expansion of a prostatic stem/ progenitor cell subpopulation and tumor initiation. Proc Natl Acad Sci 103: 1480-1485.

Wang G, Wang J, Sadar MD. 2008. Crosstalk between the androgen receptor and $\beta$-catenin in castrate-resistant prostate cancer. Cancer Res 68: 9918-9927.

Wang J, Cai Y, Yu W, Ren C, Spencer DM, Ittmann M. 2008. Pleiotropic biological activities of alternatively spliced TMPRSS2/ERG fusion gene transcripts. Cancer Res 68: 8516-8524.

Wang L, Liu R, Li W, Chen C, Katoh H, Chen GY, McNally B, Lin L, Zhou P, Zuo T, et al. 2009. Somatic single hits inactivate the X-linked tumor suppressor FOXP3 in the prostate. Cancer Cell 16: 336-346.

Wang Q, Li W, Zhang Y, Yuan X, Xu K, Yu J, Chen Z, Beroukhim R, Wang H, Lupien M, et al. 2009. Androgen receptor regulates a distinct transcription program in androgenindependent prostate cancer. Cell 138: 245-256.

Wang X, Kruithof-de Julio M, Economides KD, Walker D, Yu H, Halili MV, Hu Y-P, Price SM, Abate-Shen C, Shen MM. 2009. A luminal epithelial stem cell that is a cell of origin for prostate cancer. Nature 461: 495-500.

Wang J, Kim J, Roh M, Franco OE, Hayward SW, Wills ML, Abdulkadir SA. 2010. Pim1 kinase synergizes with c-MYC to induce advanced prostate carcinoma. Oncogene 29: $2477-$ 2487

Watson PA, Ellwood-Yen K, King JC, Wongvipat J, Lebeau MM, Sawyers CL. 2005. Context-dependent hormone-refractory progression revealed through characterization of a novel murine prostate cancer cell line. Cancer Res 65: 11565-11571.

Whang YE, Wu X, Suzuki H, Reiter RE, Tran C, Vessella RL, Said JW, Isaacs WB, Sawyers CL. 1998. Inactivation of the tumor suppressor PTEN/MMAC1 in advanced human prostate cancer through loss of expression. Proc Natl Acad Sci 95: 5246-5250.

Whitaker HC, Girling J, Warren AY, Leung H, Mills IG, Neal DE. 2008. Alterations in $\beta$-catenin expression and localization in prostate cancer. Prostate 68: 1196-1205.

Wicha, M.S., Liu, S., Dontu, G. 2006. Cancer stem cells: An old idea-A paradigm shift. Cancer Res 66: 1883-1890.

Wiklund F, Jonsson BA, Brookes AJ, Stromqvist L, Adolfsson J, Emanuelsson M, Adami HO, Augustsson-Balter K, Gronberg H. 2004. Genetic analysis of the RNASEL gene in hereditary, familial, and sporadic prostate cancer. Clin Cancer Res 10: 7150-7156.

Winter SF, Cooper AB, Greenberg NM. 2003. Models of metastatic prostate cancer: A transgenic perspective. Prostate Cancer Prostatic Dis 6: 204-211.

Wolf AM, Wender RC, Etzioni RB, Thompson IM, D'Amico AV, Volk RJ, Brooks DD, Dash C, Guessous I, Andrews K, et al. 2010. American Cancer Society guideline for the early detection of prostate cancer: Update 2010. CA Cancer J Clin 60: $70-98$.

Wu X, Wu J, Huang J, Powell WC, Zhang J, Matusik RJ, Sangiorgi FO, Maxson RE, Sucov HM, Roy-Burman P. 2001. 
Generation of a prostate epithelial cell-specific Cre transgenic mouse model for tissue-specific gene ablation. Mech Dev 101: 61-69.

Wu Z, Conaway M, Gioeli D, Weber MJ, Theodorescu D. 2006. Conditional expression of PTEN alters the androgen responsiveness of prostate cancer cells. Prostate 66: 11141123.

Wu CT, Altuwaijri S, Ricke WA, Huang SP, Yeh S, Zhang C, Niu Y, Tsai MY, Chang C. 2007. Increased prostate cell proliferation and loss of cell differentiation in mice lacking prostate epithelial androgen receptor. Proc Natl Acad Sci 104: 12679-12684.

Xiang Y, Wang Z, Murakami J, Plummer S, Klein EA, Carpten JD, Trent JM, Isaacs WB, Casey G, Silverman RH. 2003. Effects of RNase L mutations associated with prostate cancer on apoptosis induced by 2',5'-oligoadenylates. Cancer Res 63: 6795-6801.

Xin L, Ide H, Kim Y, Dubey P, Witte ON. 2003. In vivo regeneration of murine prostate from dissociated cell populations of postnatal epithelia and urogenital sinus mesenchyme. Proc Natl Acad Sci 100: 11896-11903. doi: 10.1073/ pnas. 1734139100.

Xin L, Lawson DA, Witte ON. 2005. The Sca-1 cell surface marker enriches for a prostate-regenerating cell subpopulation that can initiate prostate tumorigenesis. Proc Natl Acad Sci 102: 6942-6947.

Xin L, Teitell MA, Lawson DA, Kwon A, Mellinghoff IK, Witte ON. 2006. Progression of prostate cancer by synergy of AKT with genotropic and nongenotropic actions of the androgen receptor. Proc Natl Acad Sci 103: 7789-7794.

Xu J, Meyers D, Freije D, Isaacs S, Wiley K, Nusskern D, Ewing C, Wilkens E, Bujnovszky P, Bova GS, et al. 1998. Evidence for a prostate cancer susceptibility locus on the X chromosome. Nat Genet 20: 175-179.

Xu J, Zheng SL, Carpten JD, Nupponen NN, Robbins CM, Mestre J, Moses TY, Faith DA, Kelly BD, Isaacs SD, et al. 2001a. Evaluation of linkage and association of HPC2/ ELAC2 in patients with familial or sporadic prostate cancer. Am J Hum Genet 68: 901-911.

Xu J, Zheng SL, Chang B, Smith JR, Carpten JD, Stine OC, Isaacs SD, Wiley KE, Henning L, Ewing C, et al. 2001b. Linkage of prostate cancer susceptibility loci to chromosome 1. Hum Genet 108: 335-345.

Xu K, Shimelis H, Linn DE, Jiang R, Yang X, Sun F, Guo Z, Chen H, Li W, Kong X, et al. 2009. Regulation of androgen receptor transcriptional activity and specificity by RNF6-induced ubiquitination. Cancer Cell 15: 270-282.

Yatani R, Kusano I, Shiraishi T, Hayashi T, Stemmermann GN. 1989. Latent prostatic carcinoma: Pathological and epidemiological aspects. Ipn J Clin Oncol 19: 319-326.

Yauch RL, Gould SE, Scales SJ, Tang T, Tian H, Ahn CP, Marshall D, Fu L, Januario T, Kallop D, et al. 2008. A paracrine requirement for hedgehog signalling in cancer. Nature 455: 406-410.

Yeager M, Orr N, Hayes RB, Jacobs KB, Kraft P, Wacholder S, Minichiello MJ, Fearnhead P, Yu K, Chatterjee N, et al. 2007. Genome-wide association study of prostate cancer identifies a second risk locus at 8q24. Nat Genet 39: 645-649.

Yeager M, Chatterjee N, Ciampa J, Jacobs KB, Gonzalez-Bosquet J, Hayes RB, Kraft P, Wacholder S, Orr N, Berndt S, et al. 2009. Identification of a new prostate cancer susceptibility locus on chromosome 8q24. Nat Genet 41: 1055-1057.

Yu X, Wang Y, Jiang M, Bierie B, Roy-Burman P, Shen MM, Taketo MM, Wills M, Matusik RJ. 2009. Activation of $\beta$-catenin in mouse prostate causes HGPIN and continuous prostate growth after castration. Prostate 69: 249-262.
Yu J, Mani RS, Cao Q, Brenner CJ, Cao X, Wang X, Wu L, Li J, Hu M, Gong Y, et al. 2010. An integrated network of androgen receptor, polycomb, and TMPRSS2-ERG gene fusions in prostate cancer progression. Cancer Cell 17: 443-454.

Yuan TC, Veeramani S, Lin MF. 2007. Neuroendocrine-like prostate cancer cells: Neuroendocrine transdifferentiation of prostate adenocarcinoma cells. Endocr Relat Cancer 14: 531-547.

Zhang Z, Rosen DG, Yao JL, Huang J, Liu J. 2006. Expression of p14ARF, p15INK4b, p16INK4a, and DCR2 increases during prostate cancer progression. Mod Pathol 19: 1339-1343.

Zhang Y, Zhang J, Lin Y, Lan Y, Lin C, Xuan JW, Shen MM, McKeehan WL, Greenberg NM, Wang F. 2008. Role of epithelial cell fibroblast growth factor receptor substrate $2 \alpha$ in prostate development, regeneration and tumorigenesis. Development 135: 775-784.

Zhang L, Altuwaijri S, Deng F, Chen L, Lal P, Bhanot UK, Korets R, Wenske S, Lilja HG, Chang C, et al. 2009. NF-кB regulates androgen receptor expression and prostate cancer growth. Am I Pathol 175: 489-499.

Zhang L, Zhang B, Valdez JM, Wang F, Ittmann M, Xin L. 2010. Dicer ablation impairs prostate stem cell activity and causes prostate atrophy. Stem Cells 28: 1260-1269

Zhao XY, Malloy PJ, Krishnan AV, Swami S, Navone NM, Peehl DM, Feldman D. 2000. Glucocorticoids can promote androgen-independent growth of prostate cancer cells through a mutated androgen receptor. Nat Med 6: 703-706.

Zhao B, Wei X, Li W, Udan RS, Yang Q, Kim J, Xie J, Ikenoue T, Yu J, Li L, et al. 2007. Inactivation of YAP oncoprotein by the Hippo pathway is involved in cell contact inhibition and tissue growth control. Genes Dev 21: 2747-2761.

Zhou Z, Flesken-Nikitin A, Corney DC, Wang W, Goodrich DW, Roy-Burman P, Nikitin AY. 2006. Synergy of p53 and Rb deficiency in a conditional mouse model for metastatic prostate cancer. Cancer Res 66: 7889-7898.

Zhu P, Baek SH, Bourk EM, Ohgi KA, Garcia-Bassets I, Sanjo H, Akira S, Kotol PF, Glass CK, Rosenfeld MG, et al. 2006. Macrophage/cancer cell interactions mediate hormone resistance by a nuclear receptor derepression pathway. Cell 124: 615-629.

Zhuang L, Kim J, Adam RM, Solomon KR, Freeman MR. 2005. Cholesterol targeting alters lipid raft composition and cell survival in prostate cancer cells and xenografts. J Clin Invest 115: 959-968.

Zong Y, Xin L, Goldstein AS, Lawson DA, Teitell MA, Witte ON. 2009. ETS family transcription factors collaborate with alternative signaling pathways to induce carcinoma from adult murine prostate cells. Proc Natl Acad Sci 106: 1246512470 . 


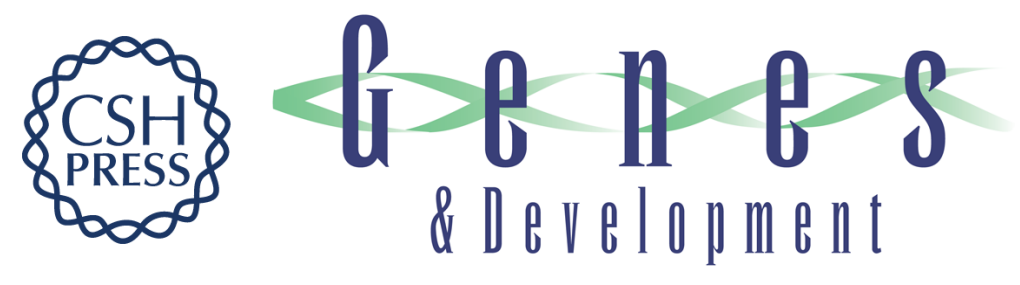

\section{Molecular genetics of prostate cancer: new prospects for old challenges}

Michael M. Shen and Cory Abate-Shen

Genes Dev. 2010, 24:

Access the most recent version at doi:10.1101/gad.1965810

References This article cites 463 articles, 185 of which can be accessed free at: http://genesdev.cshlp.org/content/24/18/1967.full.html\#ref-list-1

License

Email Alerting Receive free email alerts when new articles cite this article - sign up in the box at the top Service right corner of the article or click here.

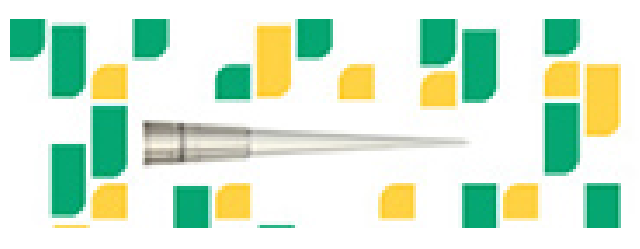

Focused on your science. 